This dissertation has been $63-4708$ microfilmed exactly as received

THAYER, John Richardson, 1929-

THE RELATIONSHIP OF VARIOUS AUDIENCE COMPOSITION FACTORS TO TELEVISION PROGRAM TYPES.

The Ohio State University, Ph.D., 1962

Speech-Theater

University Microfilms, Inc., Ann Arbor, Michigan 
Copyright by

John Richardson Thayer

1963 


\section{THE RELATIONSHIP OF VARIOUS AUDIENCE COMPOSITION FACTORS TO TELEVISION PROGRAM TYPES}

\section{DISSERTATION}

Presented in Partial Fulfillment of the Requirements for the Degree Doctor of Philosophy in the Graduate School of The Ohio State Untversity

By

John Richardson Thayer, B.A., M.A.

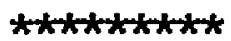

The Ohio State University 1962

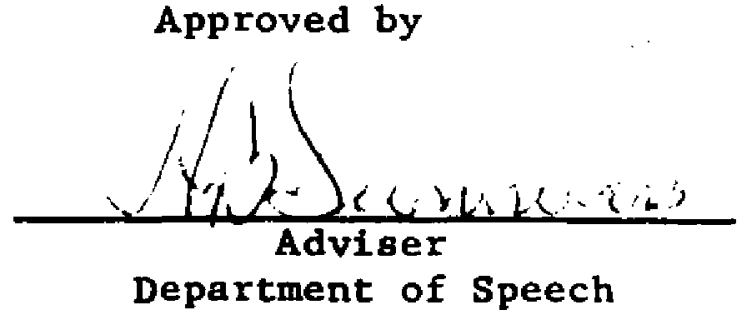


LIST OF TABLES . . . . . . . . . . . . . . . . . . . . . . . . IV

LIST OF FIGURES . . • . . . . . . . . . . . . . . . . . . . . . . vi

\section{Chapter}

I. A BRIEF HISTORY OF PROGRAM TYPES AND THEIR MMPORTANCE TO THE TELEVISION BROADCASTER

The History of Program Types on Radio

The History of Program Types on Television

The Importance of Program Types

The Hypotheses of the Study

II. A REVIEW OF THE MOST POPULAR PROGRAM TYPES . . . . . . . . 17

III. THE CATEGORIZING OF PROGRAMS INTO TYPES . . . . . . . . . 25

Difficulties Involved in Categorizing Programs

Criteria Established in Assigning Programs to

Spectfic Types

Definttions of Program Types and Speciflc Programs

Faliing within Those Types

IV. DESCRIPTION OF DATA USED IN THE STUDY . . . . . . . . .

A Brief History of the Company

ARB's Measurement Technique

ARB's Selection of Sample Homes

Selecting the Diary Families

Tabulating the Diary Results

Final Preparations for Publication

Computation Procedures

Minimum Reporting standards

V. THE RELATIONSHIP OF PROGRAM-TYPE APPEAL TO THE AGE

AND SEX OF THE VIEWER . . . . . . . . . . . . . . . .

Census Data Versus ARB Data

Viewer Availability

Other Factors Affecting Different Viewing Patterns

Average Audience to A1l Program Types

Average Audience to Specific Program Types

In Summary 
VI. THE RELATIONSHIP OF PROGRAM-TYPE APPEAL TO THE EDUCATION OF THE VIEWER . . . . . . . . . . . . .

Education of Adult Television Vlewers

Explanation of Data

Viewing Patterns of Various Education Groups

Discussion of Individual Programs

General Observations

VII. THE RELATIONSHIP OF PROGRAM-TYPE APPEAL TO THE

FAMILY INCOME OF THE VIEWER . . . . . . . . . . . . . . 123

Family Income of the Average Television Viewer

Explanation of Data

Viewing Patterns of Various Family Income Groups

Discussion of Individual Programs

General Observations

VIII. THE RELATIONSHIP OF PROGRAM-TYPE APPEAL TO

FAMIIY SIZE

Average Family Size

Explanation of Data

Viewing Patterns of Members of Different Size

Families

Discussion of Individual Programs

IX. SUMMARY AND CONCLUSIONS .................. 145

Major Findings

Age and Sex of Viewers

Education of Viewers

Income of Families from which Viewers Come

Size of Families from which Viewers Come

BIBLIOGRAPHY

AUTOBIOGRAPHY $\ldots \ldots 157$ 


\section{LIST OF TABLES}

Table

Page

1. Makeup of "Avallable" Audience, on Heekdays . . . . . .

2. Top-25 Programs by Program Types Appearing in ARB National Reports from 1952-1961 . . . . . . . . . .

3. Distribution of Viewers by Age and Sex to "Perry Mason" and "The Untouchables" . . . . . . . . . . .

4. Distribution of Viewers by Age and Sex to "The Untouchables," "Sing Along with Mitch," and "CBS Reports" ...........................

5. Computation Procedures Employed In the Production of ARB TV National Reports for October, November and December, 1961 . . . . . . . . . . . . .

6. Distribution of U.S. Population According to Age and Sex . . . . . . . . . . . . . . . . . .

7. Distribution of Viewers by Age and Sex to Program Types Telecast During the Daytime . . . . . . . . 60

8. Distribution of Viewers by Age and Sex to Program Types Telecast During the Nighttime . . . . . . . .

9. Distribution of Vlewers by Age and Sex to "The Texan" when Telecast at Different Hours of the Day . . . . .

10. Distribution of Viewers by Age and Sex to "Emie Kovacs" when Telecast at Different Hours of the Day and on Different Days of the Week . . . . . . . . .

11. Distribution of Viewers by Age and Sex to "Bonanza" when Telecast at Different Hours of the Day and on Different Days of the Week . . . . . . . . . . . .

12. Distribution of Viewers by Age and Sex to Comedy Varlety Programs (Evening) ................

13. Comparison of Total Sample Distribution with Total Viewing Characteristics of Heads of Households and Housewives by Educational Background . . . . . . . . .

14. Distribution of U.S. Population According to Education . . . . . . . . . . . . . . . . . 
15. Distribution of Viewers by Education to Program Types Telecast During the Daytime . . . . . . . . . . . 103

16. Distribution of Viewers by Education to Program Types Telecast During the Nighttime . . . . . . . . . . . 104

17. Distribution of Viewers by Education to Specific Programs ........................ 116

18. Bureau of Census and ARB Data Comparisons Relative to Family Income . . . . . . . . . . . . . . . . . . . 124

19. Distribution of Viewers by Family Income to Program Types Telecast During the Daytime . . . . . . . . . . 127

20. Distribution of Viewers by Family Income to Program Types Telecast During the Nighttime . . . . . . . . . 128

21. Distribution of Viewers by Family Income to Specific Programs . . . . . . . . . . . . . . . . . 132

22. Distribution of Viewers by Family Size to Specific Programs .. . . . . . . . . . . . . . . . 143 


\section{LIST OF FIGURES}

Figure

1. Distribution of Daytime Viewers by Family Size to Speciflc Program Types . . . . . . . . . . . . . 139

2. Distribution of Nighttime Viewers by Family Size to Specific Program Types . . . . . . . . . . . . . 140 


\section{A BRIEF HISTORY OF PROGRAM TYPES AND THEIR IMPORTANCE TO THE TELEVISION BROADCASTER}

Slightly less than four decades ago, the following article appeared in one of the leading trade publications of the time:

The day evidently is not too far removed when the typical radio program will cease being its present jumble of odds and ends put together on the general pettern of Joseph's coat. We may expect a balanced performance, to use a theatrical term, and it is not improbable that an entire evening's entertainment will be presented by the medium outlined. It should be possible to arrange such a program so as to encompass a wide variety and stili preserve the theme of continuity. 1

Such an Idea in 1925 must Indeed have been thought provoking. Up to that time little consideration had been given to refinements such as program planning. It was trouble enough for a station merely to remain on the air with a signal divorced from Interference, let alone worry about the Intricacies of program presentation.

Until the passage of the Radio Act of 1927 , government regulations imposed on broadcasting were considerably less than desirable. In those formulative years, "the engineering crudity of many early broadcast stations made them quite incapable of holding closely to an assigned frequency." 2

Several Important historical events took place in the middle

1 Radio Broadcast, VII (May, 1925), P.89.

2 Sydney W. Head, Broadcasting in America (Boston: Houghton Mifflin Company, 1956), p. 127. 
twenties, however, which helped establish the ultimate direction radio was going to take. In 1926, for instance, the American Telephone and Telegraph Company withdrew from the operation of broadcast stations, thus ending the serlous questions which had arisen regarding the future economic nature of the medium. The first radio network was established in the same year, and the first nationwide network service started the following year, 1927. Also, in 1927, the Radio Act was approved, thus ending the stormy and confused years of non-regulation. All these events plus the added technological advancements in the field made people suddenly realize what a vital role this fascinating new medium was going to play in the American way of $11 f e .^{3}$

Probably one of the first official acknowledgments of "program types" came as a result of the Radio Act of 1912. In 1921, for instance, the Act assigned news and entertainment stations to $833.3 \mathrm{kc}$., and crop and weather report stations to $618.6 \mathrm{kc} .,^{4}$ thus differentiating the various kinds of program content.

In Its never-ending struggle to produce something different, radio seriously started developing new program types commencing about the time that networks were introduced on the scene, 1926.

Undoubtedly one of the chief reasons why radio and television have surged ahead so dramatically in this country from the very start is that both media are products of a free enterprise system. They are privately owned and operated, have always expected to make a profit,

\footnotetext{
3 Ibid., P. 130.

4 Ibid., P. 127.
} 
and usually have succeeded in dolng so. During 1961, national advertisers spent more than $\$ 1,300,000,000$ at gross rates for television time alone, according to the Television Bureau of Advertising. 5 With so many radio and television stations in operation, there of course is an unimaginable amount of competition. Such competition is and always has been a favorable condition for advancing new concepts and new ideas.

When and how did radio decide that its support would come chtefly from the sale of advertising time? There are several theories and "tales" that have been compounded. Some people, for Instance, say that broadcast advertising began in 1916 over Dr. Lee de Forest's radiophone station at High Bridge in New York City. De Forest arranged with the Columbia Phonograph Company for a three-times-a-week demonstration of the latest records. Most students of broadcasting will recognize Dr. de Forest as the inventor of the three-element vacuum tube, called the heart of the broadcasting system. 6

Even though he may have been one of the first to use the medium of radio for advertising purposes (Indirect as it may have been), Dr. de Forest was later one of the first to criticize very strongly the use of the airwaves for such purposes:

I wel1 remember in 1919 when the High Bridge station began after the World War an entertainment service with occasional mention of the merits of the new variable condensers and what-

5 Broadcasting, LXII (March 19, 1962), P. 34.

6 Orrin E. Dunlap, Jr., Radio in Advertising (New York: Harper and Brothers, 1931), p. 2. 
nots my company was marketing, frequently overhearing certain disparaging remarks trom a rival West street radiophone that "they had no condensers which they were interested In selling by rad10"!

Then and there I learned the lesson that direct advertising by broadcast did not always build good will. And I have consistently condemned the practice as perverse, pernicious, reflecting on the good name of radio, and distinctly retarding its development. I did not then foresee the fine excellence of the sponsored program, or its powerful potentialities in building up the almost incredible demand for receiving apparatus. But the insidious influence of the avariclous advertiser, his stupid insistence on "-rect crass, venal advertising has, I regret to observe, become more and more effective and devastating.

As the so-called "Father of Radio Broadcasting" I raise my voice in most earnest protest against this revolting state of affairs. The all too marked tendency of the broadcast chatns and of many individual stations to lower their bars to the greed of direct advertising rapidly works to sap the lifeblood and destroy the greatest usefulness of this magnificent means of contact which we engineers have so laborlously tolled to upbuild and to perfect. If this stupid venality is not suppressed, If this reptile of etheric advertising is not scotched, we may well resign ourselves to a rapld decadence of a noble institution. The radio public is, I believe, becoming nauseated by the quality of many of the present programs. Short-sighted greed of the broadcasters, station-owners and advertising agencies, is slowly killing the broadcasting goose - layer of many golden eggs.7

Needless to say, little heed was pald to de Forest's warnings.

How he expected the industry to thrive, or better yet to survive, is not stated.

One opposing thought which is pretty widely voiced is that both radio and television would not have taken the great strides forward that they have if it had not been for advertising. "Competition

7 Ibid., pp. 2-3. 
creates pressures which are always operating to Improve the quality of programs from the point of view of popular acceptance." 8

It seems logical that competition also acted as a stimulus to create new and different program types. By tracing back through the historical years of radio and television, one can pretty well determine that this is what actually happened.

The broadcast industry is spending a considerable amount of money trying to ascertain the best possible solution of the perennial problem -- how to entice the advertiser to spend more and more of his money on radio and television time. This, of course, involves research.

Research at the present time takes many different forms: program ratings, "total homes" data, electronic program analysis, independent network, agency and station research, mail response analysis, coverage studies, and more detailed qualitative research, to mention a few.

Probably the most consistent contributors to television research (at least in amount of materials offered) are the various rating firms. Companies such as the American Research Bureau, A.C. Nielsen, Pu1se, Trendex and Videodex supply the broadcaster and advertiser with highly valuable information for making crucial business decisions. In all of these cases, it should be kept in mind that the reports produced by these companies are based on some form of sampling, and it is axlomatic

8 Judith C. Waller, Radio, the Fifth Estate (Boston: Houghton Mifflin Company, 1946), p. 8 . 
that all forms of sampling have inherent statistical errors. In an article aimed at timebuyers, Ward Dorrell, vice president and research director of John Blair and Company, expresses this idea in simple and direct terms.

Keep In mind that these figures are only estimates, having a wide range of possible variation, and that many other factors should be considered before you base serious decisions involving many thousands of dollars of your client's money on them.?

\section{A. The History of Program Types on Radio}

In studying the history of program types, since "organized" radio did not start until the inception of the networks in 1926 , it seems fitting to limit the following discussion only from that year to the present.

One of the most complete studies performed in the area of the history of radio program types was completed In 1958 at the Ohio State University. 10 While a certain amount of subjective thinking was applied in establishing programs as specific types, this study is undoubtedly one of the very few historical documents which gives a running account of virtually all programs on the air during January of each year.

Starting, then, with the 1926-1927 broadcast season, the follow-

9 Ward Dorre11, "History of Ratings," Sponsor Timebuying Basics (1955), P. 9 .

10 Harrison B. Summers, "Radio Programs Carried on National Networks 1926-1956," (unpublished study, The Ohio State University, Columbus, January, 1958). 
ing is a complete rundown of all new program types introduced during that and each succeeding broadcast year. It should once again be kept in mind that this analysis is limited to network programing only. Without question, some of the earlier years of broadcasting on Individual stations included programs falling into many of the first-mentioned program types. However, because of a lack of sufficlent information, and also because this study is based only on network programs, the historical material is also limited to that area.

Program Types Introduced In:

$\underline{1926}-\underline{1927}$

Concert Music Dayt Ime Homemakers' Talks

General Varlety

Light Music

Miscellaneous Talk Programs

Mus Ical Varlety

News, Commentary

Religious Talk Programs

$\underline{1927-1928}$

Comedy Variety

Informat Ive Drama

Light, Homey or "Love Interest" Drama

Public Affairs Talks, Forums

$\underline{1928-1929}$

H111billy, Minstrel Shows

Thrillex Drama

$1929-1930$

Children's Programs

Comedy Drama

Prestige Drama 
1929-1930 (continued)

Sem1-Variety

$\underline{1930}-\underline{1931}$

Comedy Talks

Hollywood Goss ip

$\underline{1931-1932}$

Women's Serial Drama

$\underline{1932}-\underline{1933}$

None

$1933-1934$

Human Interest

1934-1935

Amateur Contest

Sports News, Interviews

$\underline{1935}-\underline{1936}$

None

$\underline{1936}-\underline{1937}$

QuIz

$1937-1938$

Sports (play-by-play)

$\underline{1938}-\underline{-1939}$

Panel Quiz 
$\underline{1939}-\underline{1940}$

Platter Music

$\underline{1940-1941}$

Comedy Audience Participation

$\underline{1941-\underline{1947}}$

None

$\underline{1947-1948}$

Disk Jockey

$\underline{1948-\underline{1953}}$

None

$\underline{1953}-\underline{1954}$

Magazine-Type Varlety

This analysis shows that by the middle and late thirties, nearly all program types had made their appearance. Even though platter music was introduced several years previous, the disk jockey per se did not officially appear until 1947 -- at least on network radio.

B. The History of Program Types on Televiston

Since television is so closely related to radio, it of course borrowed from that medium. Therefore, since all new radio program types had been implemented by the advent of television, the majority of these types were immediately transposed to television. 
The following presents the historical record of program type appearances on television: ${ }^{11}$

Program Types Introduced In:

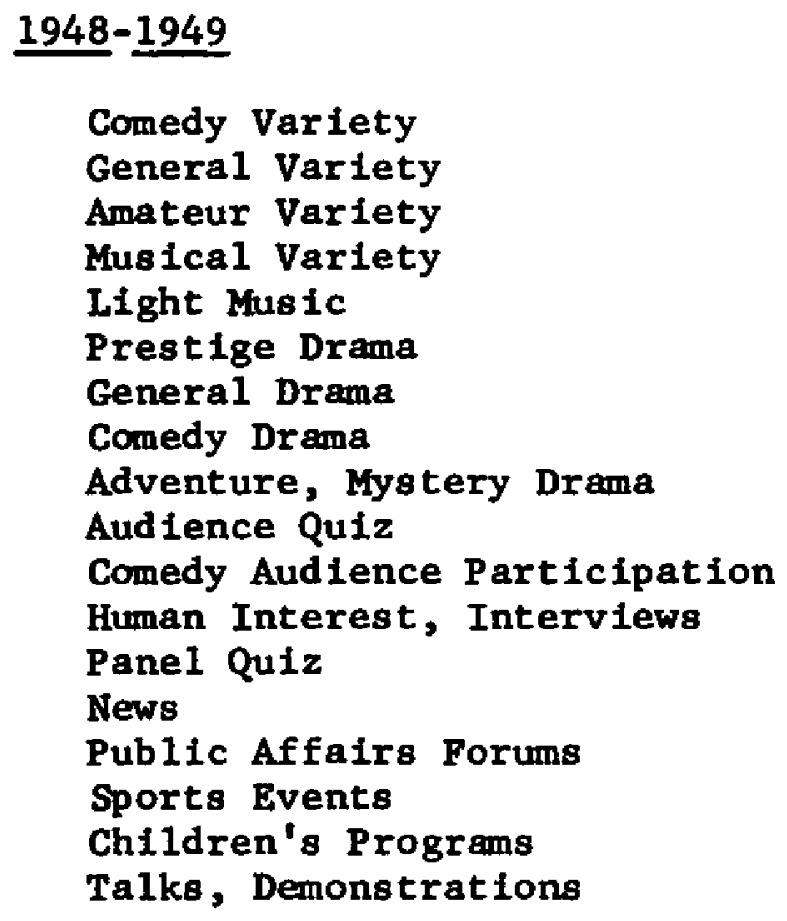

$\underline{1949}-\underline{1950}$

None

$\underline{1950-1951}$

Women's Serial Drama

$\underline{1951}-\underline{1952}$

Informative Drama

11 Harrison B. Summers, "Television Network Program Trends" (unpublished material prepared for Television Programs course, The Ohio State University, 1957), P. T-25-b. 
1952-1954

None

$\underline{1954}-\underline{1955}$

Spectaculars

\section{$\underline{1955}-\underline{1956}$}

Hillbilly Variety

Theatrical Feature Films

Again, it should be kept in mind that these program classifications are the result of one person's judgment. For instance, Westerns have been Included in the "Adventure Drama" classification, whereas in the classifications established for the study at hand, Westerns have been analyzed separately.

With the possible exception of "American Bandstand" (Teenage Dance) which was introduced in 1957-1958, no program types have appeared since 1955-1956 which are strictly "new." Varlations most certainly have come upon the scene, but no distinctly different types.

The foregoing historical background leads to two important conclusions:

(1) The early appearance of widely variant program types on television was due to a carry-over of these same types from radio.

(2) Individual program variations will continue, but few totally new program types can be expected in the future. 


\section{The Importance of Program Types}

It becomes fairly evident to most persons in the broadcasting business that different kinds of people are attracted to different kinds of programs. When this factor is taken into consideration, knowing the precise differences that exist becomes a11-important to the broadcaster and advertiser.

The advertiser, in particular, wants to capture as much of the audience as possible which Includes prime prospects for his product. A Cadillac dealer, for instance, would gain little from sponsoring a children's program. This, of course, is an extreme example, and one which almost anyone would surmise without further study. However, when other program types are considered, the answers are not so obvious. In fact, there may be wide variations within program types. One program may attract an entirely different audience than another program within the same type, because of different appeals, etc.

Robert E. Dunville, president of Crosley Broadcasting Corporation, gives the following classic example:

I think it was generally contended that wrestling appeals to men from 30 to 45 , or maybe 50 years of age. An analys 18 of wrestling in the Midwest has indicated however, that $47 \%$ of the wrestling television audiences were composed of women and, of the $47 \%$, over $60 \%$ were 40 years old, or older. Prize fights, that is the pro fights, however, appeal, according to our figures, to $97 \%$ men, slightly less than $3 \%$ women and the age group is from 20 to 45 predominantly, with a small percent being 45 or older. I mention these two program types because they are both exhibition of personal contests and, still, the make-up of the audience is entirely different. Only through 
qualitative research can these determinations be made with any degree of accuracy. 12

There are, of course, many other varlables which cause wide dif-

ferences in the make-up of a given program's audience. Jacob A. Evans, former Director of National Advertising and Promotion for the National Broadcasting Company, says that a time salesman should know the following things about a program before he offers it to prospective advertisers:

(1) The Location of the Program. To say it's "on" at 8 a.m. isn't enough. Analyze $\overline{8}$ a.m. In your market. What program precedes $8 \mathrm{a} . \mathrm{m}$. on your station? To what audience does that program appeal? Is it a successful program for its sponsor or sponsors? What program follows your $8 \mathrm{a} . \mathrm{m}$. show? Is it successful in attracting audiences? Does it have a record of selling its sponsor's goods? What programs are broadcast by other stations in your market at $8 \mathrm{a.m}$. Is the competition strong or weak? Has your strongest competition been gaining or losing during the last year? How does your station rank with other stations at 8 a.m.? Are you gaining or loging? Is your 8 a.m. program slanted to the same audience as your competitors' programs or to a different audience?

(2) The Advantages of the Time Period. What are people doing In your town at $8 \mathrm{a} \cdot \mathrm{m}$, ? Who is at home listening to the radio? When do most people go to work in your city? When do the children go to school? When do housewives go shopping? (If yours is the "typical" city, $8 \mathrm{a} . \mathrm{m}$. will find this situation: At $8 \mathrm{a} \cdot \mathrm{m}$. an advertiser can reach the entire family, before the husband goes to work, before the kids go to 8 chool and, importantly, before the housewife shops. He will reach the family during the impressionable early morning hours before they have become saturated with advertising of all types. If yours is a market with television, $8 \mathrm{a} . \mathrm{m}$. On radio will be attractive because of relatively weak competition from TV.) 13

12 Robert E. Dunville, "What Qualitative Research Does," Sponsor Timebuying Basics (1955), p. 30 .

13 Jacob A. Evans, Selling and Promoting Radio and Television (New York: Printers' Ink Publishing Company, Inc., 1954), Pp. 25-26. 
Evans goes on with discussion pertinent to the content of the program, the commercial appeal, and the historical record of the program. However, the above questions illustrate the point very well, without going into further detall, that many factors are Involved in the actual composition of a given program's audience.

In discussing the time of day, another interesting question arises. Who is "available" for listening or viewing at different hours of the day? A very revealing study was performed at the ohio State University in 1959,14 which should prove very worthwhile to advertisers trying to make decisions regarding the time placement of programs or spot announcements. Table 1 is a condensed version of the findings, broken down by total men, women, teenagers and children.

It was found that no matter what the hour of the day, a substantially greater number of women than men were "at home and available to 1isten." Similarly at every hour, the number of available listeners over 40 years of age was greater than the number of 1 isteners from 19 to 40 years of age.

Since this study is limited to the city of columbus, and is further limited to Monday through Friday only, no other conclusions can be made regarding (1) the country as a whole, or (2) the makeup of the available audience on Saturday and Sunday. More research is definttely needed in this area. However, this pilot study acts as an important guide toward further analysis.

14 Howard E. Hopf and Raymond T. Bedwe1l, Jr., "Characteristics and Program Preferences of Television Listeners in Columbus, Ohio," (unpublished study conducted at The Ohlo State University, 1959), p. 4. 
TABLE 1

MAKEUP OF THE "AVAILABLE" AUDIENCE, ON WEEKDAYS

(Average numbers of men, women and chlldren in each sex-age group, per 1000 of total population in Columbus, who

were at home, awake and "available" to listen

to radio or TV, during each 60 -minute period)

\begin{tabular}{|c|c|c|c|c|c|c|c|c|c|c|}
\hline $\begin{array}{r}\text { Sex-Age } \\
\text { Groups }\end{array}$ & $\begin{array}{l}\text { Total } \\
\text { per } 1000 \\
\text { pop'n }\end{array}$ & $\begin{array}{r}7 \\
\mathrm{AM} \\
\end{array}$ & $\begin{array}{r}9 \\
\mathrm{AM} \\
\end{array}$ & $\begin{array}{l}11 \\
\underline{\mathrm{AM}} \\
\end{array}$ & $\begin{array}{r}1 \\
\underline{P M} \\
\end{array}$ & $\begin{array}{r}3 \\
\text { PM } \\
\end{array}$ & $\begin{array}{r}5 \\
\underline{P M} \\
\end{array}$ & $\begin{array}{r}7 \\
\underline{P M} \\
\end{array}$ & $\begin{array}{r}9 \\
\text { PM } \\
\end{array}$ & $\begin{array}{l}11 \\
\underline{P M} \\
\end{array}$ \\
\hline $\begin{array}{l}\text { Ch1 1dren } \\
(0-13)\end{array}$ & 269 & 141 & 104 & 88 & 69 & 104 & 185 & 209 & 80 & 21 \\
\hline $\begin{array}{l}\text { Teenagers } \\
(14-18)\end{array}$ & 63 & 43 & 4 & 5 & 5 & 11 & 43 & 45 & 50 & 20 \\
\hline $\begin{array}{l}\text { Men } \\
\text { (19 plus) }\end{array}$ & 312 & 109 & 51 & 51 & 50 & 54 & 142 & 208 & 214 & 119 \\
\hline $\begin{array}{l}\text { Women } \\
\text { (19 plus) }\end{array}$ & 356 & 225 & 240 & 238 & 215 & 217 & 264 & 284 & 287 & 163 \\
\hline TOTALS & 1000 & 518 & 399 & 382 & 339 & 386 & 634 & 746 & 631 & 323 \\
\hline
\end{tabular}

D. The Hypotheses of the Study

Many of the conclusions of this study have been hypothesized time and time again, but in some cases, little or no evidence has been given to support them.

The hypotheses which will be discussed in this presentation are as follow:

(1) Programs of any given type attract a different audience in the daytime than they attract at night. 
(2) The audience composition of programs within any given type w111 vary considerably due to:
a. differing appeals
b. competitive programing at the same time

(3) Each program type is watched primarily by viewers of a specific age and sex.

(4) Each program type is watched primarily by viewers of a specific educational background.

(5) Each program type is watched primarily by viewers coming from a family falling within a specific income bracket.

(6) Each program type is watched primarily by viewers coming from a specific size family.

It is hoped that the findings presented herein will prove valuable to the radio and television scholar as well as the commercial broadcaster. 
Mention was made in Chapter I of the extreme competition which exists in the radio and television media.

In the constant search to find and to develop "hit" programs, each network is in vigorous competition with other networks, and every station competes with other stations in the same geographic area. Not only does the competition extend to programing effectively against the competitive programing of the other networks and stations, since they are seeking to attract the same audience, but also to the finding of new hit programs. Thus, a new hit on one network may have a devastating effect on the program broadcast at the same time by a rival network, as well as on adjacent programs. The big networks, always under the pressure to win a majority of the available audience, usually try to meet program strength with program strength, which explains why two big hour variety shows or hour dramas may be scheduled at the same time over rival networks. 1

The same reasoning can be applied to radio and television programming in general. What has proven to be a success in the past is quite apt to be used as a guide for upcoming network schedules. One or two programs which fall within a specific type happen, for one reason or another, to become hits overnight. Because of this, the networks, agencies, producers, syndicators and the like, have a marked tendency to rush to the public with more programs of the same type, tailored carefully with the same basic ingredients of their successful forerunners.

BBDo's George Polk says, "There is too much accent on trends in programming. The public wants entertainment, not types. I maintain that the public is always looking for good entertainment. It's circumstances

1 Giraud Chester and Garnet R. Garrison, Television and Radio (New York: Appleton-Century-Crofts, Inc., 1956), p. 53. 
that make for trends, not the public." 2 such is the reasoning of a leading agency.

An article in Television Magazine sums it up this way:

Increasingly there is good audience in store for the best concelved and executed shows in many programing categories, woe for the mediocre. Perhaps there is a new destre on the part of the viewer for quality, not as to program type, but as to quality of individual shows within a type. ${ }^{3}$

Another programing authority, Mitchell Johnson, vice president and television director of William Esty, observes that television "is a cyclical business, just like the movies." He, however, deplores the "trends" pattern because "people Im1tate too closely instead of Innovating. 14

Television has seen many such years of imitation. Quiz programs, Westerns and Action Adventures have all been a part of the cycle. Each type had its turn as the "favorite" of the year. Some were lucky and lasted for several seasons before finally shrinking back to normalcy again; others were relatively short-1ived. As historical background material, this chapter will take a look at the most popular program types, at least over the last ten-year period. Before this is attempted, however, it should be pointed out that the viewing audience can be expected to react only within the scope of

\footnotetext{
2 Television Age, IX (June 11, 1962), p. 30 .

3 Television Magazine, XIX (March, 1962), p. 62

4 Television Age, IX (June 11, 1962), p. 30 .
} 
the overall programing it is offered. To use an extreme example (in radio):

... By 1940 , the technique of reaching the housewife's ear had been reduced to a formula. The formula was not always pretty but 1 t was effective.

Sponsors of programs aimed at selling merchandise to housewives had discovered that adding listeners" teardrops to the dishwater was big business. Daytime serials had become the biggest thing in radio, whether you considered them from a standpoint of broadcast time, expenditure of the advertising dollar, listening interest or effectiveness in selling what the sponsor had to offer.

The average network station, in 1940 and 1941, devoted five hours -- In fifteen-minute programs -- to daytime serials designed to entice women to buy household items. Add to that the two hours devoted to persuading kids to persuade their mothers to buy a certain type of cereal or bread because, with each box top or wrapper, the youngster would recelve a badge making him a genuine Junior G-Man, or a mask Identical with that worn by the Lone Ranger, and you've cut quite, a swathe in a day's broadcasting schedule of sixteen hours. 5

What the above implies is simply thls: If only one program is offered within a given type, it cannot possibly stand as much of a chance in a popularity race as a type which is represented by ten different programs. Thls factor should be kept in mind, then, while reading the remainder of Chapter II, which discusses the most popular program types from 1952 through 1961.

It was felt that a review of the programing trends over the last ten-year perlod would prove extremely worthwhile to those readers desiring a more complete historical background. To make such a review,

5 Francis Chase, Jr., Sound and Fury (New York: Harper and Brothers, 1942), pp. 178-179. 
the writer assembled a11 of the November TV National Reporta from 1952 through 1961, as compiled by the American Research Bureau, a nationwide televiaton rating $\mathrm{fl \textrm {rm }}$.

Program ratings were used as the basic data for comparison purposes. Because of this, the September, 1960 report was substituted for the November report of that year, since, in 1960, ratings were not pub11shed in November. Working, then, with these ten reports, and 1imitIng the discussion to the top-rated 25 programs in each case, the following analyses were made:

(1) Average number of programs of each type appearing in toprated 25 over the ten-year period.

(2) Average rating of programs in top-rated 25 falling in each program type over the ten-year period.

It would appear that the "number of programs" is a more meaningful criterion of popularity than the average ratings of programs since an examination of Table 2 shows relatively little difference In program ratings. The majority of the ratings tended to fal1 in the low and middle 30's. One type (Talent Contests) succeeded in achieving the highest rating (43.9), but this figure represents an average of only four programs. To say, then, that Talent Contests was the most popular type because it had the highest rating would be rather misleading. In terms of the number of programs appearing in the top-rated 25 shows, Table 2 shows that Situation Comedy was the "most popular" program type over the past ten-year period. It is interesting to note that In several instances the same program was in the top-25 Iine-up for 
several years. "I Love Lucy," for instance, appeared in first place from 1952 through 1954. In 1955 it was in second place, and the following year it was in the seventh position.

The situation comedy, a creature of TV, has been its longest stand-by. The antics of Lucy were TV's greatest success story, and even now are minting riches in re-runs. Though much maligned, situation bids fare to overwhelm all other types of humor on IV, as witness the current season. In audience terms, there's a reason: when they're good, they're very very good, and even the bad aren't bad.6

In 1954 alone, $81 x$ of the top-rated 25 programs were situation Comedy types: "I Love Lucy," "Burns and Allen," "Our Miss Brooks," "Life of Riley," "My Little Margie" and "Private Secretary."

General Drama, with thirty-three programs appearing, was the second most popular type. Westerns, on the other hand, occupted a close third position, with thirty-one programs.

It Is Interesting to note, however, that General Drama was far more stable throughout the years than Westerns. With the postible exception of "The Lone Ranger" (which could concelvably be classifled as ChIldren's Drama), the first Western did not make the top-25 11sting unt 11 1957, when flve programs were Included ("Gunsmoke," "Tales of We11s Fargo," "Restless Gun," "Wyatt Earp" and "Wagon Train"). With the exception of "Restless Gun," all of these programs appeared again In 1958, In addition to "Have Gun, Will Travel," "Maverick," "The RIfleman" and "Sugarfoot."

In 1959 , the ultimate was achieved when $40 \%$ of the top- 25 programs were Westerns. Excluding "Sugarfoot" and "Tales of We1ls Fargo,"

6 Television Magazine, XVIII (February, 1961), p. 30. 
all of the 1958 favorites appeared again, along with four newcomers: "The Texan," "Lawman," "Rawhide" and "Wanted, Dead or Alive."

TABLE 2

TOP-25 PROGRAMS BY PROGRAM TYPES APPEARING IN ARB NATIONAL REPORTS FROM 1952-1961

(by number of programs and average ratings)

\begin{tabular}{|c|c|c|}
\hline Program Type & $\begin{array}{l}\text { Number of programs } \\
\text { appearing in top- } 25 \\
\text { over } 10 \text {-year period }\end{array}$ & $\begin{array}{l}\text { Average } \\
\text { program } \\
\text { rating }\end{array}$ \\
\hline $\begin{array}{l}\text { S1tuation Comedy } \\
\text { General Drams } \\
\text { Westerns } \\
\text { Comedy Variety } \\
\text { Audience Participation } \\
\text { Musical Variety } \\
\text { Crime Detective } \\
\text { General Varfety } \\
\text { Game Panel } \\
\text { Children's Drama } \\
\text { Human Interest } \\
\text { Children's Educational } \\
\quad \text { Variety } \\
\text { Suspense Drama } \\
\text { Action Adventure } \\
\text { Specials } \\
\text { Talent Contests } \\
\text { Sports Events }\end{array}$ & $\begin{array}{r}41 \\
33 \\
31 \\
23 \\
19 \\
18 \\
16 \\
15 \\
14 \\
7 \\
7 \\
5 \\
\\
5 \\
4 \\
4 \\
4 \\
3\end{array}$ & $\begin{array}{l}34.8 \\
33.4 \\
32.6 \\
36.1 \\
37.2 \\
32.8 \\
33.7 \\
38.4 \\
34.3 \\
29.6 \\
31.9 \\
35.2 \\
27.4 \\
29.5 \\
38.4 \\
43.9 \\
35.7\end{array}$ \\
\hline
\end{tabular}

an1y 24 programs were listed in 1960; otherwise, toṭal would have been 250 .

Weighted according to number of programs within each type.

A study performed in 1960 for Campbel1-Ewald (an advertising agency) by Soctal Research, Incorporated showed that "westerns, riding 
the crest for several years, emerge ... as being on the downgrade."7

This observation seems to have held true, since in 1960 only three Westerns made the top-25 11sting ("Wagon Train," "Bonanza" and "Gunsmoke").

The same study states, however, that "dramatic programs have stabilized their position in relation to other programs."8 This stability was in evidence throughout the ten-year period under discussion.

Except for the lean years of 1958, 1959 and 1960, when only one General Drama program appeared in the top-25 ("Loretta Young" in each Instance), all other years found from three to six programs appearing. Twenty-three programs appersed in the Comedy Variety category, placing it in fourth position. As will be discussed in Chapter III, the programs falling within comedy Variety are not as homogeneous as would be desired. Fomats of Individual programs within a serles oftentimes vary quite drastically, making it sometimes difficult to say positively that the series as a whole is Comedy Variety.

Audience Participation and Musical Variety programs were close contenders for fifth and sixth places respectively. Nineteen individual programs were recorded for Audience Particlpation, as opposed to eighteen for Musical Variety.

In immediate succession were Crime Detective, General Varlety and Game Panel, with sixteen, fifteen and fourteen programs each, in the same order.

7 Televfsion Magazine, XVIII (May, 1961), p. 41.

8 Loc. clt. 
The remaining elght program types which appeared were represented by an average of 1 ess than one program per year over the ten-year perlod: Children's Drama and Human Interest each had seven; Children's Educational Varlety and Suspense Drama had five each; Action Adventure, Spectals and Talent Contests were represented with four each; and finally, Sports Events had only three programs to its credit. These, then, were the past decade's most popular program types, according to individual program ratings published by ARB.

As will be re-emphasized in Chapter III, the classification of programs is based on a considerable amount of subjective thinking. Therefore, minor differences might be expected to appear in the data presented in this chapter if another authorlty were asked to classify the same group of programs. This thought should be kept in mind, not only in reference to ehapter II, but in forthcoming chapters involving program classification. 


\section{THE CATBgORIZING OF PROGRAMS INTO TYPES}

If a person were to ask ten different authorities in broadcasting to Itemize all program types now In existence on television, he would undoubtedly receive ten completely different answers. No one could justiflably say which one would be the correct 11st of types; within the frame of reference of the persons doing the categorizing, all of them probably could be considered correct. Amazing similarities unquestionably would be found, however, between all ten lists.

Without question, there are programs which fall into no distinct categories. For purposes of this study, these programs either (1) have been completely Ignored since they would add nothing of great significance to the general findings, or (2) have been handled separately.

Questions concelvably will arise as to the author's method of categorizing programs. In order to minimize the number of questions, it seems appropriate at this time to define the program types established for this study, and 11 st the programs included in each type.

Before this is attempted, however, it is necessary to point out some of the problems with which one is confronted in categorizing programs. Beyond a certain point, it 18 almost necessary to make an arbitrary decision as to where certain programs belong.

\section{A. Difficulties Involved In Categorizing Programs}

One of the hypotheses set forth in Chapter I was that programs within any given type vary considerably in audience composition due to 
different appea1s within the structure of the program. A second hypothesis of equal significance to this discussion is that the same program type will attract a significantly different audience at varlous times of the day.

For instance, both "Perry Mason" and "The Untouchables" can, broadly speaking, be classifled as Crime Detective. However, when the program content of each is analyzed, the following dissimilarities become quite evident:

\section{PERRY MASON}

1. Outright violence played down as much as possible.

2. Guilty character not divulged unt11 end of program.

3. Perry Mason portrayed as 11keable individual.

4. Essentially a "courtroom" drama .
THE UNTOUCHABLES

1. Violence $\$ s$ keyword to success of program.

2. Guilty character generally known throughout program.

3. Elliot Ness portrayed as rather cold and Indifferent.

4. Story takes place in streets of Chicago.

These four highly conflicting differences are probably significant enough to seriously alter the attractiveness of each program among the potential viewers. To elaborate on some of the audience composition differences inherent in these programs, Table 3 shows which spectfic age and sex groups are attracted to each program.

"Perry Mason" attracts primarily older viewers of both sexes, whereas "The Untouchables" is particularly favored by young adults, 18 to 
39 years old, again both sexes. Women over 40 make up slfghtly more than half the female audience to "Perry Mason." In fact, females dom1nate all age categortes in number of viewers per 100 homes.

TABLE 3

DISTRIBUTION OF VIEWERS BY AGE AND SEX TO

"PERRY MASON" AND "THE UNTOUCHABLES"

(by average number of persons per 100 homes tuned to the program)

\begin{tabular}{|c|c|c|c|c|c|c|c|c|c|c|c|}
\hline \multirow[b]{2}{*}{ Program } & \multicolumn{2}{|c|}{ Under 13} & \multirow{2}{*}{$\frac{13}{M}$} & \multirow{2}{*}{$\frac{-17}{F}$} & \multirow{2}{*}{$\frac{18}{M}$} & \multirow{2}{*}{$\frac{-39}{F}$} & \multirow{2}{*}{$\frac{40}{M}$} & \multirow{2}{*}{$\frac{\mathrm{Plus}}{\mathrm{F}}$} & \multicolumn{3}{|c|}{ Totals } \\
\hline & $\mathbf{M}$ & $\mathbf{F}$ & & & & & & & $\overline{\mathbf{M}}$ & $\mathbf{F}$ & $\overline{\text { ALL }}$ \\
\hline Perry Mason & 15 & 17 & 7 & 8 & 23 & 34 & 47 & 62 & 92 & 121 & 213 \\
\hline Untouchables & 7 & 5 & 10 & 7 & 42 & 46 & 38 & 34 & 97 & 92 & 189 \\
\hline
\end{tabular}

"The Untouchables," on the other hand, has an overa11 audience consisting of more males than females, although the difference probably is not statistically significant.

What are some of the possible reasons why these differences exist, other than because of different program structure?

(1) "Available" audience may be different for each program due to:

(a) Early versus late evening time slots.

(b) Thursday evening versus Saturday evening positions.

(2) Programs presented on other stations at same time are also competing for an audience.

According to the Hopf-Bedwe11 Study, the breakdown of people

1 Howard E. Hopf and Raymond T. Bedwe11, Jr., "Characteristics and Program Preferences of Televiston Listeners in Columbus, Ohio," (unpublished study conducted at The Ohio State University, 1959), p. 4. 
"at home, awake, and in the house" varies considerably from hour to hour throughout the day. As Chapter I stated, the survey was limited only to Columbus and its suburbs; however, the results nevertheless suggest that similar differences exist throughout the country. For instance, in Columbus more children under 14 and more adults over 40 presumably were available during the hour when "Perry Mason" was telecast than during the hour when "The Untouchables" was telecast.

However, since the Columbus study is based only on weekdays, and since "Perry Mason" was carried on Saturday, another possible varlable is introduced. A reasonable assumption is that younger children are given somewhat more freedom on Friday and Saturday evenings than on eventngs preceding school-days. Therefore, the "audience profile" of "The Untouchables" might concelvably have changed markedly insofar as children under 14 are concerned, if it had been programmed either on Friday or Saturday night.

What was the result of competitive programming on the audience profile of these two programs? Several speculations can be made. From 10:00 to 11:00 PM, Thursday evening, "The Untouchables," "Sing Along with Mitch," and "CBS Reports" shared the viewing audience. As was previously established, "The Untouchables" appealed primarily to young adu1ts, 18 to 39 years old. Both "Sing Along with Mitch" and "CBS Reports," however, got the bulk of their audiences from people over 40, primartly women.

Table 4 shows how these three competing programs shared the viewing audience.

From this analysis of viewing distribution, it is seen that teen- 
agers and young children composed a very small portion of the total audience viewing television during the hour in question. Therefore, this segment can be regarded as relatively insignificant to the whole.

\section{TABLE 4}

DISTRIBUTION OF VIEWERS BY AGE AND SEX TO "THE UNTOUCHABLES," "SING ALONG WITH MITCH," AND "CBS REPORTS"

(by average number of persons per 100 homes tuned to the program)

\begin{tabular}{|c|c|c|c|c|c|c|c|c|c|c|c|}
\hline \multirow[b]{2}{*}{ Program } & \multicolumn{2}{|c|}{ Under 13} & \multirow{2}{*}{$\frac{13}{M}$} & \multirow{2}{*}{$-\frac{17}{F}$} & \multirow{2}{*}{$\frac{18}{M}$} & \multirow{2}{*}{$\frac{-39}{\mathbf{F}}$} & \multicolumn{2}{|c|}{40 plus } & \multicolumn{3}{|c|}{ Tota1s } \\
\hline & $\overline{\mathbf{M}}$ & $\mathbf{F}$ & & & & & $\mathbf{M}$ & $\mathbf{F}$ & $\overline{\mathbf{M}}$ & $\mathbf{F}$ & $\overline{A I L}$ \\
\hline Average Audience ${ }^{\theta}$ & a 6 & 7 & 7 & 6 & 32 & 41 & 41 & 51 & 86 & 105 & 191 \\
\hline Untouchables & 7 & 5 & 10 & 7 & 42 & 46 & 38 & 34 & 97 & 92 & 189 \\
\hline Sing Along & 6 & 9 & 4 & 5 & 25 & 39 & 43 & 63 & 78 & 116 & 194 \\
\hline CBS Reports & 3 & 1 & 8 & 2 & 32 & 32 & 40 & 51 & 83 & 86 & 169 \\
\hline
\end{tabular}

awelghted according to ratings recelved by each program.

However, all other age and sex categorles are highly significant. "Sing Along with Mitch" and "CBS Reports" were particularly appealing to women past 40 .

It should be kept in mind, though, that because a program has a certain segment of the population in its audience does not necessarily mean that the program is "appealing" to that segment. If "The Untouchables" had been the only program carried at 10:00 o'clock, Thursday evening, it seems reasonable to assume that the audience characteristics might have been very different, simply because there would have been no other programs from which to choose. The point that competitive programing "steals" Important segments of an otherwlse receptive audience Is a very Important one. 
B. Criterla Established in Assigning Programs to Specific Types

Taking into consideration the more important variables mentioned above, the following criteria were established for examining each program prior to assigning it to a particular type.

(1) Does the general program content fall within the definition established for the program type?

(2) More specifically, does the pattern of viewing remain relatively constant for all programs within a given type? If not, can these differences be logically explained (hour of telecast, competitive programing, etc.)?

To further refine the categories, programs have been split into two factions:

(1) Daytime -- Monday through Sunday, sign-on to 6:00 PM

(2) Nighttime -- Monday through Sunday, 6:00 PM to sign-off

If programs falling within the same types apply to both the daytime and nighttime criteria (such as "The Price Is Right"), they will be discussed separately, since the available audience is hypothetically different.

Granted, other important "availability" differences undoubtedly exist throughout the course of any given day. However, to split the day into further segments would lead to confusion. Nevertheless, in all cases where the viewing pattern of a specific program is altered significantly for one reason or another, that program will be discussed separately, and probably in combination. 
C. Definitions of Program Types and Spec1fic

Programs Faling Within Those Types

The following definftions have been established for purposes of broadly categorizing specific programs:

ACTION ADVENTURE

Definition: Dramatic programs in which the elements of action and adventure are clearly evident. Each story is usually complete in itself and Involves one or more leading characters.

Programs included in type:

Daytime: None

Nighttime: Adventures in Paradise

Bus Stop

Checkmate

Follow The Sun

Frontier Circus

Hawailan Eye

Route 66

Straightaway

Surfside 6

77 Sunset Strip

\section{AUDIENCE PARTICIPATION}

Definition: Programs in which the studio audience is the prime consideration. Usually some kind of quiz format is used, but in any case, human interest is always an important element.

Programs included in type:

Daytime: Camouflage

Concentration

It Could Be You

Jan Murray

Make A Face

Number Please

Password

Play Your Hunch

Price Is Right 
Queen for A Day

Say When

Seven Keys

Surprise Package

Truth or Consequences

Video Village

Who Do You Trust

Yours for A Song

Nighttime: Price Is Right

Yours for A Song

Children's

version: Video Village, Jr.*

* To be handled separately

\section{CARTOON COMEDY}

Definition: Animated programs either consisting of several cartoon "shorts" or one complete story.

Programs Included in type:

Daytime: King Leonardo

Mighty Mouse

Nighttime: Alvin Show

Bugs Bunny

Bullwinkle

Calvin and The Colonel

Flintstones

Matty's Funnies

Top Cat

CHILDREN'S DRAMA

Definition: Dramatic programs, other than animation, almed specifically at children under twelve years of age.

Programs included in type:

Daytime: Fury

My Friend Flicka

Roy Rogers

Sky King 
Nighttime: Lassie

National Velvet

\section{CHIIDREN'S VARIEIY}

Definition: Programs, other than dramatic or cartoon comedy, aimed specifically at children and teenagers.

Programs included in type:

Daytime: Captain Kangaroo

Magic Land of Allakazam

Mr. Wizard*

Plp The Plper

Shart Lewis

Nighttime: $1,2,3$ - Go

* To be discussed separately

\section{COMEDY VARIETY}

Definition: Variety programs in which the basic element of comedy is predominant. Usually comedy 18 based around star of program, but in some cases, "acts" involving other comedians may be included. Programs usually contain musi cal segments as a means for accomplishing variety.

Programs included in type:

Daytime: None

Nighttime: Bob Newhart*

Ernie Kovacs*

Jack Benny*

Red Ske1ton*

Steve Allen*

* Since each of these programs is highly different in content and audience appeals, each w111 be analyzed and discussed separately, as well as in combination. 


\section{CRIME DETECTIVE}

Definition: Dramas, complete in themselves, depicting efther the prevention of crime, or the solution of a crime already committed.

Programs included in type:

Daytime: None

$\begin{array}{ll}\text { Nighttime: } & \text { Cain's Hundred } \\ \text { Defenders } \\ \text { Detectives } \\ \text { 87th Precinct } \\ \text { Investigators } \\ \text { Naked City } \\ \text { New Breed } \\ \text { Perry Mason } \\ \text { Roaring Twentles } \\ \text { Target: The Corruptors } \\ \text { Untouchables }\end{array}$

CONCERT MUSIC

Definftion: Programs containing music of a classical or semi-classtcal nature. Music 1s, of course, the prime ingredient of the program.

Programs included in type:

Daytime: $\quad$ None

Nighttime: Telephone Hour

DOCUMENTARY

Defintion: Programs of a non-fictional nature dealing with important historical places and events.

Programs included in type:

Daytime: None

Nighttime: Circle Theatre

Twentieth Century 
FEATURE FILMS

Definttion: Full-length dramas on motion picture film produced primarily for theatre audiences.

Programs included in type:

Daytime: None

Nighttime: Saturday Night at The Movies

GAME PANEL

Definition: Programs contalning a panel of regular members, with a moderator who also acts as master of ceremonies. Panel members are usually show people, many of whom host their own programs.

Programs included in type:

Daytime: None

Nighttime: I've Got A Secret

To Tel1 The Truth

What's My Line

GENERAL DRAMA (half-hour)

Definttion: Adult plays not exceeding thirty minutes in length. Each program is complete in itself.

Programs included in type:

Dayt Ime: Loretta Young

Millionaire

Nighttime: G. E. Theatre

Window on Main Street

GENERAL DRAMA (one hour)

Definttion: Adult plays one hour in length especially produced for television. Does not include feature films produced primarily for theatre audiences. 
Programs Included in type:

DaytIme: None

Nighttime: Alcoa Premiere

Ben Casey

Dick Powe11

Dr. Kildare

Theatre ' 62

U. S. Steel Hour

Westinghouse Presents

GENERAL VARIETY

Definition: Programs including a varlety of elements such as music, comedy, "acts," guest stars, etc. Always has a master of ceremonies, and sometimes a permanent cast.

Programs included in type:

Daytime: House Party

Nighttime: Ed Sullivan

Garry Moore

Golden Showcase

Jack Paar*

* This program will be discussed by itself and will not be Included as part of the General Variety averages.

\section{MUSIC VARIETY}

Definition: Programs primarily concerned with popular music and "old favorites." Other acts are intermixed throughout the format to satisfy the element of variety.

Programs included in type:

Daytime: None

Nighttime: Dinah Shore

Lawrence Welk

Perry Como

Sing Along with Mitch 
NEWS

Definftion: Programs that deal primartly with news events of the past twenty-four hours. Little or no interpretation 18 given.

Programs included in type:

Daytime: None

$\begin{array}{ll}\text { Nighttime: } & \text { ABC News } \\ \text { ABC News Final } \\ \text { Douglas Edwards } \\ \text { Huntley-Brinkley } \\ \text { Saturday Report } \\ \text { Sunday News Special }\end{array}$

PUBLIC AFFAIRS

Definition: Programs that deal primarily with the discussion of current events. Usually one or two topics are discussed in detail, along with interpretation. Sometimes includes editorializing.

Programs included in type:

Daytime: Chet Huntley

Nighttime: CBS Reports

Eyewitness

Here and Now

Meet The Press

Great Challenge

Nation's Future

Brinkley's Journal*

Today*

* These programs will be discussed by themselves and wil not be included as part of the Public Affairs averages.

QUIZ PANEL

Definition: $\quad$ Programs consisting of panels of unknown personalities competing for scholarly honors by answering relatively difficult questions in the fields of arts and sciences. 
Programs included in type:

Daytime: $\quad$ G: E. College Bowl

Nighttime: None

SITUATION COMEDY

Definition: Dramatic programs dependent upon a comedy situation for advancement of plot. Each story is complete in itself.

Programs included in type:

Dayt1me: I Love Lucy

Love That Bob

Make Room for Daddy

Nighttime: Andy Griffith

Bachelor Father

Bob Cumming 8

Car 54, Where Are You?

Danny Thomas

Dennts The Menace

Dick Van Dyke

Dobie Gillis

Donna Reed

Father Knows Best

Father of The Bride

Hathaway 8

Haze1

Hennesey

Ichabod and Me

Joey Bishop

Leave It to Beaver

Margie

Mister Ed

Mrs. G. Goes to College

My Three Sons

Ozzle and Harriet

Pete and Gladys

Real McCoys

SPORTS EVENTS

Definftion: All programs including play-by-play descriptions of actual sports events. 
Programs included in type:

$\begin{array}{ll}\text { Daytime: } & \text { All Star Golf } \\ & \text { American Football League } \\ \text { Game of The Week } & \text { Gotham Bowl } \\ \text { NBA Basketball } \\ \text { NCAA FootbalI } \\ \text { NFL Footbal1 } \\ \text { Pro Footbal1 (NBC) } \\ \text { Pro Footbal1 (CBS) } \\ \text { Nighttime: } \\ \text { Fight of The Week } \\ \text { Make That Spare }\end{array}$

SUSPENSE DRAMA

Definition: Dramas dependent upon the element of suspense in the fulfillment of the plot.

Programs included in type:

Daytime: None

Nighttime: Alfred Hitchcock

Thriller

Twillght Zone

\section{TALENT VARIETY}

Definition: Programs using little-known or amateur talent who compete against each other for prizes or honors.

Programs included in type:

Daytime: Amateur Hour

Nighttime: None

TEENAGE DANCE

Definition: Programs afmed specifically at the teenager interested in popular music and dancing.

Programs included in type:

Daytime: American Bandstand 
Nighttime: None

\section{WESTERNS}

Definition: Dramatic programs based on a nineteenth century western theme. Usually Involves gunplay, but not a necessary element of each individual program.

Programs Included in type:

Daytime: Texan

\begin{tabular}{|c|c|}
\hline Nighttime: & $\begin{array}{l}\text { Bonanza } \\
\text { Cheyenne } \\
\text { Gunsmoke } \\
\text { Have Gun, Will Travel } \\
\text { Laramie } \\
\text { Lawman } \\
\text { Marshal Dillon } \\
\text { Maverick } \\
\text { Outlaws } \\
\text { Rawhide } \\
\text { Rifleman } \\
\text { Tall Man } \\
\text { Wagon Train } \\
\text { Wells Fargo }\end{array}$ \\
\hline
\end{tabular}

WOMEN'S SERIAL DRAMA

Definition: Dramatic programs aimed specticically at the daytime women's audience. Installments are not complete in themselves, but are continuous over several weeks or years.

Programs included in type:

Daytime: As The World Turns

Brighter Day

Edge of Night

From These Roots

Gulding LIght

Love of Life

Search for Tomorrow

Secret Storm

Young Dr. Malone

Nighttime: None 
Other programs which may not conveniently fall within any of these types will be analyzed separately at appropriate times throughout the text of the study, provided they are felt to be of significance. 


\section{DESCRIPTION OF DATA USED IN THE STUDY}

The basic data used in complitng the information found in this study were taken from three consecutive National Television Audience Reports published by the American Research Bureau, hereafter referred to as ARB.

\section{A. A Brief History of the Company}

The American Research Bureau, a leading national television rating service, was started in 1949, when 1 ts present director, James $W$. Seiler, inttiated television surveys in the three cities of Baltimore, Philadelphia and Washington, D. C. Now, thirteen years later, the research firm surveys the entire Untted States (including Alaska and Hawa11), and offers the following additional services: national reports published $81 x$ times per year; local reports for all television markets in the country (from two to ten times per year, depending upon the size of the market); coverage reports for all television stations in the United States; market reports covering Canadian viewing to United States stations; telephone colncidental studies; TV station management analyses; instantaneous rating data in New York City; special surveys and special tabulations suited to Individual client needs.

\section{B. ARB's Measurement Technique}

The basic research tool employed by ARB in measuring the national television audience is the "viewer diary," which has been used by the 
company since 1949. This "viewing record," as it is sometimes called, is destgned to measure all viewing which takes place in each sample home by all members of the family. The viewing behavior of each individual is recorded in a separate audience column. Every diary keeper 1s asked to keep an accurate record of his family's viewing habits for one complete week and, at the end of this time, to return the completed diary to ARB's production headquarters in Beltsville, Maryland.

There are many arguments "for" and "against" all techniques which test sample cases, and it is conceded by the author that there is no infallible method of finding the so-called "truth." It therefore seems appropriate at this time to introduce the various advantages and disadvantages of the viewer diary technique.

(1) Advantages of the diary technique, as used by ARB

(a) All members of a family are represented in the viewing pattern established by the completed diary. Unlike the telephone colncidental method, the diary is a family project and is not limited to one person's viewpoints, biases, etc.

(b) The diary technique is one of the most economical methods of gathering information.

(c) Information is gathered concurrently (or shortly thereafter) with the actual viewing, thereby reducting recall to a minimum.

(d) Un1ike the telephone colncidental method which is limited to the daytime and early evening hours, the diary covers 
a11 hours of the broadcast day, including early morning and late evening.

(e) Actual viewing 18 recorded in the diary, not merely set operation.

(f) Audience composition breakdowns can easily be made when the diary method is used.

(g) Extensive qualitative data can be developed since demographic information recorded in the back of the diary can be used for cross-tabulations.

(h) The diary records viewing to all sets in multiple-set homes.

(i) The diary is adaptable to any survey area, regardless of size.

(j) Since the diary measures one complete week of viewing, valuable special tabulations can be made which are impossible with some other techniques. For instance, cumulative studies (the number of different families exposed to spectfic time periods) can easily be developed.

(2) Disadvantages of the diary technique

(a) Final tabulated results take longer to produce than some other well-known methods, such as the telephone coincidental technique.

(b) There is a danger that people do not fill in their diaries immediately upon viewing a program, thereby introducing faulty recall. 
(c) The rate of cooperation to keep a diary is much less than some other well-known measurement methods. During the 1961 calendar year, for Instance, forty-eight percent of the families who originally agreed to participate in a given survey, did not return a diary as they had promised. 1

The third disadvantage, listed above, is not meant to imply that the diary method produces results significantly different than a method enjoying a higher rate of return. In fact, experiments performed by ARB in 1955 and 1956 indicate that television audience ratings obtained from diary homes do not differ appreciably from those obtained by the telephone colncidental method, where the rate of cooperation is nearly one-hundred percent. 2

It would appear that the advantages of the diary technique outweigh the disadvantages as a system to measure television viewing habits. However, as ARB points out, "While the diary has many advantages, these lose their meaning if the original source -- the diary itself -- is lacking in accuracy or is invalid in any way." ${ }^{3}$ with this in mind, ARB maintains a continuous program of testing, validation and study of the diary as a measurement device.

1 Interview with Mrs. Isabel Brown, ARB Field Staff Supervisor, Fehruary, 1962.

2 A New Look at the Television Viewer Dlary (pamphlet issued by the American Research Bureau, 1956), 16 pp.

3 TV Measurement for the Sponsor (booklet issued by the American Research Bureau, 1958), P. 39 . 


\section{ARB's Selection of Sample Homes}

As might be expected, ARB's sampling procedures have changed somewhat over its thirteen-year existence. Experiments with various techniques have resulted in refinements being introduced wherever deemed necessary. Therefore, it seems proper to limit the description of the sampling procedure that follows to the specific reports used in compiling this study (October, November and December, 1961).

"The method used in selecting the sample for the ARB TV Nationals is direct and simple. In effect, the entire United States is treated as one large universe or area to be sampled." 4

It should be pointed out in the beginning of this discussion, however, that the basic sample design of the United States is established first and foremost with the local TV market reports in mind. The TV National merely works within the framework already set up.

The first step in national sample selection was to prepare a 11 st of sampling units (previously designed for local market measurement). A sampling untt can be described as one or more counties, or portions of counties, in the universe which is handled as a single entity. ARB, for the most part, followed the county boundary lines when establishing sampling units. However, there were certain instances when this was not feasible. For instance, if a mountain range split a county, causing substantial differences in viewing habfts, such a county was oftentimes measured as two distinct sampling units. Each side of the mountain was 
considered as an entity in itself, thereby eliminating any possibility of Improper diary diatribution.

There are other instances where it was more feasible, as well as more economical, to measure counties as clusters. If contiguous countles had similar viewing characteristics, for instance, ARB usually clustered them unless other problems made it more desirable to sample them individually. For the 1961-1962 broadcast year, some 1600 ARB sampling units were established in the United States.

As the list of sampling units was being prepared, the number of television homes was also enumerated for each unit. The total number of TV homes for the entire country was then divided by the desired number of different sampling points. Such a procedure ylelded the "sampling interval" (the numerical spacing between points to be sampled). Beginning with a random starting point in the list of sampling units, the sampling interval was applied successively to obtain the location of each sampling point. 5

During the months when ARB surveyed the entire country for individual market measurement (November and March), a 1500-point nationa1 sample was established. In other words, at 1500 different randomly selected points, ARB placed enough diaries to insure at least a total return of 1500 completed and usable diaries. In this case, each point represented one returned diary for tabulation purposes. The 1500-point sample was used in the compilation of the November, 1961 report included in this study.

5 TV Measurement for the Sponsor, 1oc. cit. 
A 300-point sample was used during all other months when the TV National was produced. This, in effect, means that each point represented five returned and usable diaries. Such a sampling procedure was implemented for the October and December, 1961 reports.

The following Illustrates how the November, 1961 sample was selected:

Starting with ARB sampling unit \#0101, containing Lauderdale County, Alabama, and continuing numerically throughout the entire list of sampling units, each point was drawn at a televiston home interval of 31,924 , after a random starting point was inftially selected.

In choosing the TV National points within a sampling unte, usually the points with the greatest number of television homes were selected, provided these were also points for local market measurement. To 11lustrate, if a sampling point for the TV National fell in sampling unit \#9242, containing Cumberland County, Maine, since Portland (a local market report point) was the community in the unft with the greatest number of TV homes, then it would have been chosen as the point for placement of national diaries.

The same basic procedure was used in drawing the sample for the October and December reports, with the exception that there was a 300point interval implemented for these two months. In this case, each point was drawn using a television home interval of 159,620 , after selecting the random starting point. 


\section{Selecting the Dlary Families}

A11 homes included in the TV National sample were chosen at random from the telephone directory. No attempt was made to contact nontelephone homes owning television sets.

After the proper number of families was selected from the phone directories at the applicable sampling points, the following interviewer procedures were used.

ARB made three Interviews with each diary family. The first, completed about two weeks before the measurement period, determfned if the home had a TV set and solicited the family's co-operation; the second was made one or two days before the measurement period began, to make certain the diary had been recelved and that the family members understood its purpose (all diaries were malled directly to the participating family from ARB's Washington headquarters). The final interview was made on the third or fourth day of the "diary week" to insure that the diary was being properly kept and would be returned promptly. A self-matler accompanied each diary, and the family was directed to return it to ARB immediately after the end of the survey. 6

For several years, accurate records have been kept by ARB's Field Staff Department regarding the rate of diary return from each sampling unit in the United States. Therefore, the number of diary placements made durtng the months involved In this study depended upon past performance within a given area. Some sections of the South, for Instance,

6 Ibid., p. 41. 
have had a much lower rate of return in the past than other sections of the country. For this reason, in 1961, ARB started including a fiftycent plece with each diary malled to historically low-return areas. Indications to the date of this writing show a higher rate of return as a result.

\section{E. Tabulating the Diary Results}

The diaries that went into the tabulation of the reports involved In this study were processed in the following manner. As stated previously, all diaries were mailed directly from the sample homes located throughout the country to the production plant in Beltsville, Maryland. The first step at the plant was to carefully edit for completeness and clarity. At this stage it is estimated that about two to three percent of the diaries were discarded either because of illegibility or lack of proper entries on one or more pages. 7

After the editing process, the diaries were sent to a tabulation team responsible primarily for the ARB TV National Report. These specially trained tabulators recorded diary entries on master tabulating sheets which were carefully checked at several stages. It is estimated that approximately 15,000 completed sheets were prepared for the three reports included in this study. 8 For this reason, the study at hand is based on program "averages" as printed in the published reports, rather

\section{Ibld., P. 42 .}

8 Interview with Mr. David Dale, Coordinator for ARB TV National Reports, February, 1962. 
than the raw data avaflable only from these tabulation sheets. The use of these sheets would not only have been highly impractical, but almost Impossible.

When the tabulation was completed, the resulting sheets were sent to the Keypunch Room, where the Information was transferred to Remington Rand 90-column punched cards. The cards were then released to the Data Processing Department where they were carefully sorted and verified by machine prior to thelr delivery to the Univac Solid-state Computer for data computation and final report printing.

\section{F. Final Preparations for Publication}

The final report "print-out" was presented to the Research Control Department, which consists of a team of experts specially trained in detecting inconsistencies with previous reports, and checking out these inconsistencies for verification. In addition to these quality control checks, this department also composed the final "copy" and checked it for continuity prior to its submission to ARB's contract printer in Washington, D.C. It was the printer's responsibility to photograph, reduce and reproduce each page for inclusion in a pocket-size report. The final product was then delivered to ARB and distributed by ARB's mailing section to clients throughout the country.

\section{G. Computation Procedures}

In October, 1961, the total number of television homes in the United States was estimated by ARB to be $48,450,000$. The total number of tabulated diaries processed for incluston in the report was 1461. 
ARB also estimated that during the month of October, $94 \%$ of the television homes in the country contained people avallable for viewing (the remaining $6 \%$ were not available at any time during the survey week because of vacations, broken sets, etc.). Therefore, an "avallability factor" of 94\% was applied to the original total television homeg estimate of 48,450,000 (see Table 5).

TABLE 5

COMPUTATION PROCEDURES EMPLOYED IN THE PRODUCTION OF ARB TV NATIONAL REPORTS FOR OCTOBER, NOVEABER AND DECEMBER, 1961

\begin{tabular}{lrrr}
\hline \hline Computation & October & November & December \\
\hline Total TV homes estimate (U.S.) & $48,450,000$ & $48,550,000$ & $48,650,000$ \\
Availability factor & $94 \%$ & $94 \%$ & $95 \%$ \\
Adjusted TV homes estimate & $45,543,000$ & $45,637,000$ & $46,217,500$ \\
Total tabulated diaries & 1461 & 1384 & 1455 \\
Homes per diary value & 31,172 & 32,975 & 31,765 \\
\hline
\end{tabular}

Th1s means that $45,543,000$ homes $(94 \%$ of $48,450,000)$ were estimated as having one or more persons available for television viewing at least some time during each week. By dividing this adjusted figure by 1461 (total tabulated diaries), a "homes-per-diary-value" of 31,172 was formulated. This means that each time a program was found 11 sted in a diary, that program was credited with 31,172 television homes.

For comparative purposes, Table 5 shows the above computation procedures for the month of October, as well as for the months of November and December. 
H. Minimum Reporting Standards

For the October TV National Report, ARB used the following minimum standards when reporting detalled audience characteristics:

(1) Programs telecast once-a-week: $1,500,000$ or more homes reached.

(2) Programs telecast five-times-a-week: an average of 800,000 or more homes reached.

In effect, this means that 49 diaries were required before a once-a-week program was reported in detall, and 129 diaries were necessary for a program telecast five-times-a-week, Monday through Friday. The reason for the different standards is due to the fact that several of the 129 diaries hypothetically could come from familles viewing a Monday-through-Friday program several days of the week, whereas the 49diary criterion is based on different families in all instances.

ARB's procedure changed, however, effective with the November TV National, wherein all programs which reported viewing in excess of 320,000 homes were carried in the reports. This indicates that as few as ten diaries were responsible for some of the data published in the latter two reports covered by this study.

From a statistical standpoint, such a small sample is highly questionable. However, since even a small sample provides an Indication, it was decided by ARB not to withhold these data from the broadcasting industry .

For purposes of this study, however, the original minimum standards have been maintained. Programs in the November and December reports 
which are based on raw data not equal to or exceeding these minimum standards have been onftted from the final computations. 
THE RELATIONSHIP OF PROGRAM-TYPE APPEAL TO THE AGE AND SEX OF THE VIEWER

In order to place the following discussion in its proper perspective, it is first necessary to examine the latest Census data in terms of the total number of persons per 100 homes living in the United States .

\section{A. Census Data Versus ARB Data}

Because of the age-sex breakdowns reported by the Bureau of the Census, it is impossible to establish a table comparable to the age-sex breakdowns included in this study. However, the Census age breaks are In general keeping with the study, and become useful guides, even though they are somewhat dissimilar in makeup.

Other differences which exist in the Census data are:

(1) The Census Information Includes "group quarters"1 whereas this study is based on "households" only.

(2) The Census information includes all households and group quarters, regardless of television or telephone ownership. ARB's data, of course, are dependent upon base figures including only television-owning homes. Also, only telephone-

1 Group quarters are living arrangements for institutional inmates, armed forces personnel or other groups containing five or more people unrelated to the person in charge. 
owning homes have the capability of participating in an ARB survey.

Once again, however, the Census data presented in Table 6 can still serve as a useful gulde. In effect, the table shows the number of potential persons avallable in the United States in each age-sex category, making it somewhat easier to understand the "persons per 100 viewing homes" concept which will be used throughout the remainder of this presentation. As a word of caution, these data can be rather confusing unless they are thoroughly understood. For instance, it is altogether

TABLE 6

DISTRIBUTION OF U.S. POPULATION ACCORDING TO AGE AND SEX 2

(by average number of persons per 100 homes)

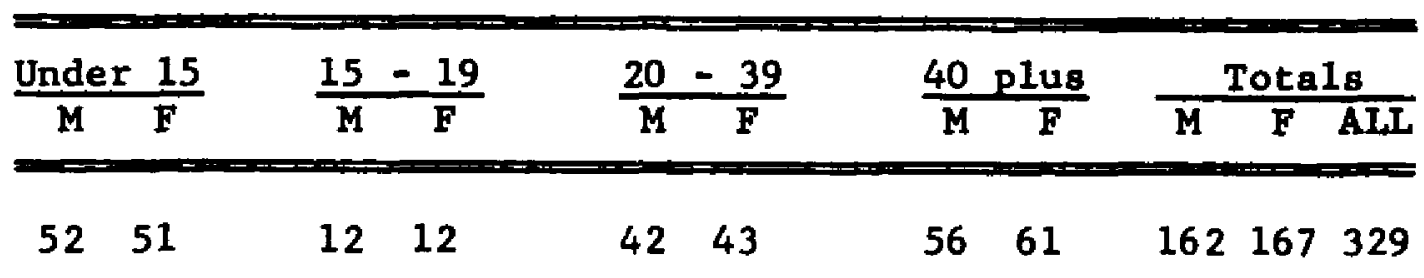

possible for the number of persons per 100 viewing homes in a spectfic age-sex category to exceed the total number of persons in the same category based on Census data. The reason for this is that the data reported for any given program or program type are in relation to IV viewing homes only, whereas Census data are in relation to all homes. For instance,

2 U.S. Bureau of the Census, U.S. Census of Population: 1960. General Social and Economic Characteristics, United States Summary. Fina1 Report PC(1) - IC (U.S. Government Printing Office, Hashington, D.C., 1962), PP. 1-199, 1-200, 1-210. 
perhaps a program attracts homes which have an above-average number of small children (Cartoon Comedy would be a good example). Since there are more children per home In the program's sample than normally exist in the "average" U.S. home, then the corresponding results would naturally tend to be higher.

Number of persons per 100 viewing homes. The phrase "number of persons per 100 viewing homes," while being quite precise and descriptive, is rather cumbersome if it has to be repeated often. Therefore, in the context of the study that follows, the writer will oftentimes refer to "viewers per 100 homes" which, in effect, will mean the same thing. In other words, when reference is made to a "home," unless otherwise designated, that home should always be considered as a "home in which television is turned on."

\section{B. Viewer Avallability}

In studying the popularity of specific program types in relation to the age and sex of viewers, striking differences were noted throughout. Some of these differences were undoubtedly due to factors previous1y pointed out in Chapter III.

"Avallability" was unquestionably one of the most important of these factors. A comparison of Tables 7 and 8 1llustrates the wide variation which existed between daytime and nighttime viewing audiences. There were two major dissimllarities: first, the average number of persons per 100 viewing homes was much less during the day (161) than 1t was during the evening (209); and second, the number of viewing children decreased in the evening, but at the same time, this decrease was accom- 
panied by a very substantial increase in both men and women viewers.

It is interesting to note that women viewers, 18 years of age and older, dominated men In sheer numbers throughout the entire broadcast day. Even more interesting is the fact that while men viewers increased in numbers quite noticeably from daytime to nighttime, the number of women viewers also increased almost proportionately. By converting "persons per 100 viewing homes" into percentages, it is found that $39 \%$ of the daytime adult audience (18 years and older) was composed of men; during the evening hours this figure increased slightly to $43 \%$. It appears that even though more women than men were presumably "at home, awake, and avallable" to view television during the daytime, a large percentage of them were pre-occupied with other activities.

This discussion brings up another important point. When was a person consldered a "viewer" In this study? ARB's viewing diary specifles that these instructions be followed when making entries each day:

Place an " $X$ " in the proper columns to indicate the persons who wexe paying attention to TV for 5 minutes or more. Count those who were either watching or listening. If the set was on but no one was paying attention, write in the time and station and " $O$ " under al1 columns.3

The factor of paying attention either visually or aurally, then, was the key as to whether or not a person was considered in a given program's audience. For example, the TV set may have been turned on in a specific home, but because the housewife was pre-occupled with other activities, and consequently not "paying attention," she was not included In the total number of viewers to that particular program. It should be

3 Copied from instruction page included in TV National diary. 
recognized, however, that such a technlque of reporting was wholly dependent upon each diary-keeping home's interpretation of "paying attention."

\section{Other Factors Affecting Different Viewing Patterns}

An examination of Table 7 reveals that the most popular program types (daytime) among adult male viewers were Sports Events, Public Affalrs and Talent Variety, in that order. A closer examination shows, however, that all programs included in these three types were telecast either on Saturday or Sunday. If these same programs were telecast at the same time of day on a Monday-through-Friday basis, chances are that the number of men per 100 homes would decrease sharply. Again, this undoubtedly would be a reflection of the "avallability" factor.

With the exception of several children's programs and one Situation Comedy, all programs included in Table 7 were telecast on a Mondaythrough-Friday basis. In no case did the male audience (adult) exceed 25 persons per 100 viewing homes during any of these weekday (M-F) programs. This maximum was reached in the case of Teenage Dance, and was followed closely by Westerns and Audience Participation (23 persons per 100 viewing homes), and General Variety (22 persons per 100 viewing homes).

What happened to the audience composition of a program when the same program was telecast on a different day and at a different time? The answer is a simple one: it changed very markedly. One would expect, from the preceding discussion, that this difference would have been more pronounced in a daytime versus nighttime situation. Without a doubt, this was probably true in the study at hand. 
TABLE 7

DISTRIBUTION OF VIEWERS BY AGE AND SEX TO PROGRAM TYPES TELECAST DURING THE DAYTIME

(by average number of persons per 100 homes tuned to the type)

\begin{tabular}{|c|c|c|c|c|c|c|c|c|c|c|c|c|c|}
\hline \multirow[b]{2}{*}{ Program Type } & \multirow{2}{*}{$\begin{array}{l}\text { No. } \\
\text { Pgme }\end{array}$} & \multirow[b]{2}{*}{$\mathbf{R}^{\mathbf{b}}$} & \multirow{2}{*}{$\frac{\text { Under }}{\mathbf{M}}$} & \multirow{2}{*}{$\frac{13}{F}$} & \multicolumn{2}{|c|}{$13-17$} & \multicolumn{2}{|c|}{$18-39$} & \multirow{2}{*}{$\frac{40}{M}$} & \multirow{2}{*}{$\frac{\text { plus }}{\text { F }}$} & \multicolumn{3}{|c|}{ Tota18 } \\
\hline & & & & & $\overline{\mathbf{M}}$ & $\bar{F}$ & $\overline{\mathbf{M}}$ & $\mathbf{F}$ & & & $\overline{\mathbf{M}}$ & $\bar{F}$ & $\overline{\text { ALL }}$ \\
\hline $\begin{array}{l}\text { Average Audience } \\
\text { to A11 Types }\end{array}$ & 59 & (7) & 29 & 28 & 6 & 5 & 14 & 25 & 22 & 32 & 71 & 90 & 161 \\
\hline $\begin{array}{l}\text { Talent Variety } \\
\text { Genera1 Varlety }\end{array}$ & $\begin{array}{l}1 \\
1\end{array}$ & $\begin{array}{l}(7) \\
(7)\end{array}$ & $\begin{array}{r}21 \\
9\end{array}$ & $\begin{array}{l}24 \\
13\end{array}$ & $\begin{array}{l}7 \\
2\end{array}$ & $\begin{array}{r}10 \\
2\end{array}$ & $\begin{array}{r}25 \\
4\end{array}$ & $\begin{array}{l}28 \\
32\end{array}$ & $\begin{array}{l}44 \\
18\end{array}$ & $\begin{array}{l}58 \\
62\end{array}$ & $\begin{array}{l}97 \\
33\end{array}$ & $\begin{array}{l}120 \\
109\end{array}$ & $\begin{array}{l}217 \\
142\end{array}$ \\
\hline $\begin{array}{l}\left.\text { Gen'1 Drama ( } \frac{1}{2} h r\right) \\
\text { Situat Ion Comedy } \\
\text { Westerns } \\
\text { Women's Serials }\end{array}$ & $\begin{array}{l}2 \\
3 \\
1 \\
9\end{array}$ & $\begin{array}{l}(6) \\
(6) \\
(2) \\
(7)\end{array}$ & $\begin{array}{r}9 \\
39 \\
22 \\
5\end{array}$ & $\begin{array}{r}10 \\
52 \\
22 \\
7\end{array}$ & $\begin{array}{l}1 \\
9 \\
3 \\
1\end{array}$ & $\begin{array}{l}5 \\
7 \\
3 \\
2\end{array}$ & $\begin{array}{l}6 \\
5 \\
8 \\
4\end{array}$ & $\begin{array}{l}46 \\
28 \\
33 \\
48\end{array}$ & $\begin{array}{r}12 \\
9 \\
15 \\
10\end{array}$ & $\begin{array}{l}42 \\
25 \\
32 \\
51\end{array}$ & $\begin{array}{l}28 \\
62 \\
48 \\
20\end{array}$ & $\begin{array}{r}103 \\
112 \\
90 \\
108\end{array}$ & $\begin{array}{l}131 \\
174 \\
138 \\
128\end{array}$ \\
\hline $\begin{array}{l}\text { Audience Part'n } \\
\text { Quiz Panel }\end{array}$ & $\begin{array}{r}17 \\
1\end{array}$ & $\begin{array}{r}(4) \\
(10)\end{array}$ & $\begin{array}{l}13 \\
16\end{array}$ & $\begin{array}{l}14 \\
16\end{array}$ & $\begin{array}{r}3 \\
10\end{array}$ & $\begin{array}{r}2 \\
12\end{array}$ & $\begin{array}{r}5 \\
21\end{array}$ & $\begin{array}{l}34 \\
27\end{array}$ & $\begin{array}{l}18 \\
44\end{array}$ & $\begin{array}{l}52 \\
57\end{array}$ & $\begin{array}{l}39 \\
91\end{array}$ & $\begin{array}{l}102 \\
112\end{array}$ & $\begin{array}{l}141 \\
203\end{array}$ \\
\hline Public Affairs & 1 & (6) & 8 & 5 & 4 & 2 & 22 & 23 & 51 & 64 & 85 & 94 & 179 \\
\hline Sports Events & 9 & (10) & 15 & 5 & 12 & 3 & 39 & 14 & 51 & 20 & 117 & 42 & 159 \\
\hline $\begin{array}{l}\text { Children's Drama } \\
\text { Children's Var'ty } \\
\text { Cartoon Comedy }\end{array}$ & $\begin{array}{l}4 \\
4 \\
2\end{array}$ & $\begin{array}{r}(9) \\
(11) \\
(9)\end{array}$ & $\begin{array}{l}68 \\
77 \\
82\end{array}$ & $\begin{array}{l}67 \\
80 \\
81\end{array}$ & $\begin{array}{r}10 \\
3 \\
6\end{array}$ & $\begin{array}{l}9 \\
2 \\
5\end{array}$ & $\begin{array}{l}8 \\
4 \\
4\end{array}$ & $\begin{array}{r}14 \\
9 \\
4\end{array}$ & $\begin{array}{l}9 \\
3 \\
3\end{array}$ & $\begin{array}{r}11 \\
6 \\
4\end{array}$ & $\begin{array}{l}95 \\
87 \\
95\end{array}$ & $\begin{array}{r}101 \\
97 \\
94\end{array}$ & $\begin{array}{l}196 \\
184 \\
189\end{array}$ \\
\hline Teenage Dance & 1 & (8) & 25 & 29 & 16 & 36 & 12 & 35 & 13 & 23 & 66 & 123 & 189 \\
\hline Miscellaneous & 3 & (5) & 44 & 45 & 10 & 6 & 9 & 17 & 20 & 33 & 83 & 101 & 184 \\
\hline
\end{tabular}

$a_{A 11}$ data are welghted for each program type according to individual ratings recelved by the programs included within each type.

$b_{\text {Average rating. }}$

As an example, Table 7 includes Westerns in Its 11sting. Only one daytime program qualified for the three-month average, that being "The Texan," a Monday-through-Friday "re-run" telecast from 11:00 to 11:30 AM on the ABC Television Network. If the audience composition data for this 
TABLE 8

DISTRIBUTION OF VIEWERS BY AGE AND SEX TO PROGRAM TYPES

TELECAST DURDNG THE NIGHITIME

(by average number of persons per 100 homes tuned to the type)

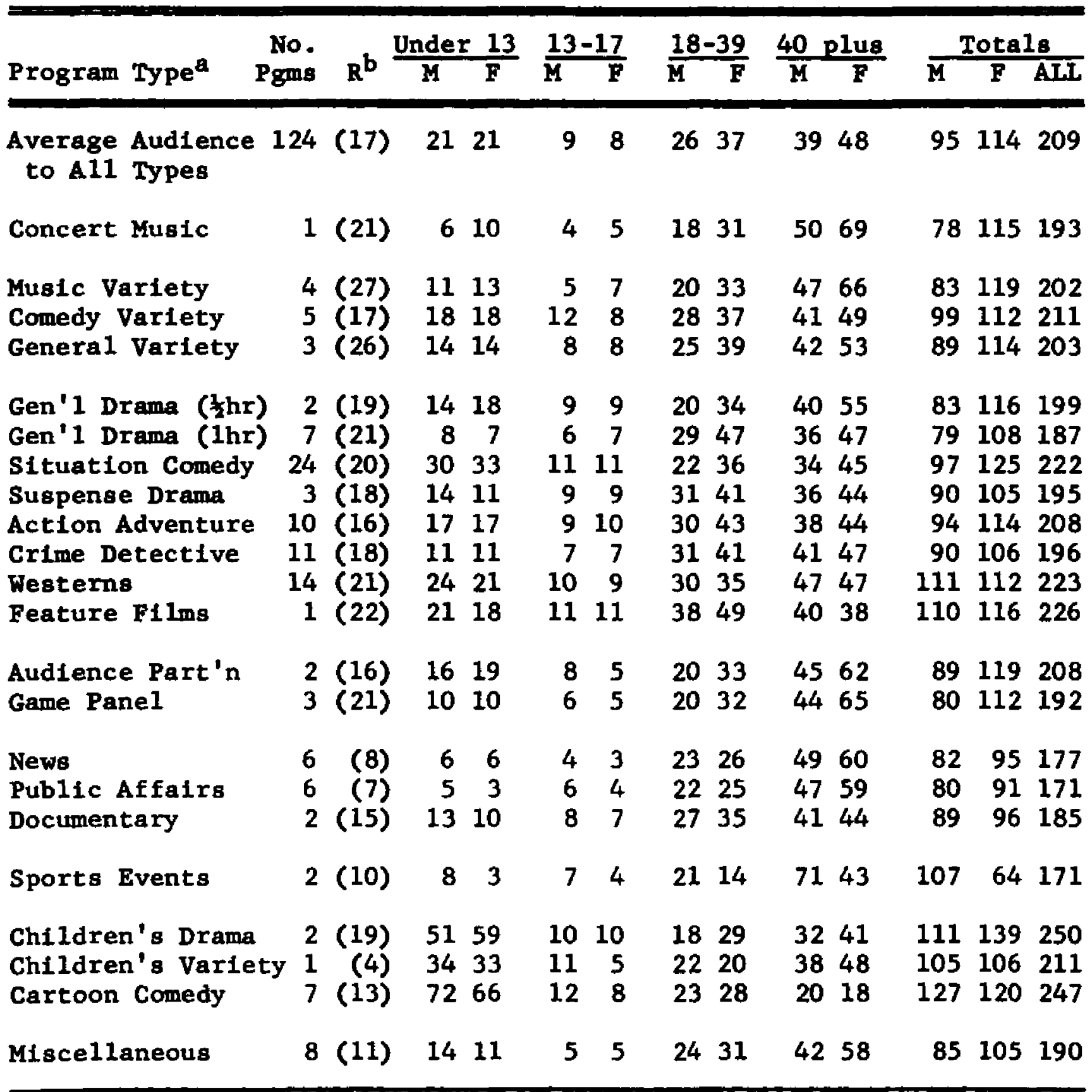

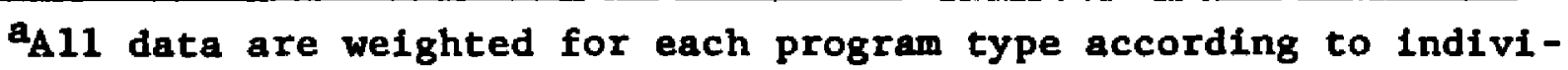
dual ratings received by the programs included within each type.

buverage rating. 
time period are analyzed with comparable data of the same program when it was scheduled from 8:00 to 8:30 PM, Monday evening (November, 1959) on a "first-run" basis, several dissimilarities become apparent. First, the rating ${ }^{4}$ dropped from a 30 , when the program was telecast in the evening, to a 2 when it was changed to daytime television. This means that during the average telecast of "The Texan" in November, 1959, some 12,710,000 television-owning homes in the United States are estimated to have had their sets tuned to the program for five minutes or more. However, during the average dally telecast of the program when it was presented on a "re-run" basis, only 902,000 television homes were estimated to have viewed the program.

Second, the average number of persons per 100 viewing homes was significantly different for the two time periods under study. Table 9 shows that the audience within the average viewing home during the daytime telecsst of "The Texan" was only 60\% (138 viewers per 100 homes) that of the evening telecast (229 viewers per 100 homes).

The most significant reason for this drop was the absence of male viewers, particularly 18 years of age and older. Again, this seems to be a reflection of "avallability." The majority of males in this age category apparently were at work and unable to view television during the average weekday. Likewlse, the drop in teenage viewing can probably be attributed to the same factor, except in this case, attendance in school undoubtedly was the reason for the low persons-per-100-

4 A rating can be defined as the percent of all television homes within a given area (in this case, the entire U.S.) tuned to a specific program at a specific time. 
homes data. While there was a drop in number of older women viewers (40 plus), the overall decrease of female viewers was nowhere near as marked as that of male viewers.

\section{TABLE 9}

DISTRIBUTION OF VIEWERS BY AGE AND SEX TO "THE TEXAN" WHEN TELECAST AT DIFFERENT HOURS OF THE DAY

(by average number of persons per 100 homes tuned to the program)

\begin{tabular}{|c|c|c|c|c|c|c|c|c|c|c|c|c|c|}
\hline Day of & & & Unde & 13 & 13 & & 18. & 39 & 40 & plus & & Cota & \\
\hline Broadcast & Hour & $\mathbf{R}^{\mathbf{a}}$ & $\mathbf{M}$ & $\bar{F}$ & $\mathbf{M}$ & $\bar{F}$ & & $\overline{\mathbf{F}}$ & $\mathbf{M}$ & $\mathbf{F}$ & $\overline{\mathbf{M}}$ & $\mathbf{F}$ & $\overline{A L I}$ \\
\hline Monday & 8:00 PM & (30) & 30 & 21 & 9 & 8 & 32 & 33 & 49 & 47 & 120 & 109 & 229 \\
\hline $\begin{array}{l}\text { Monday thru } \\
\text { Friday }\end{array}$ & $11: 00 \mathrm{AM}$ & (2) & 22 & 22 & 3 & 3 & 8 & 33 & 15 & 32 & 48 & 90 & 138 \\
\hline
\end{tabular}

Average rating.

An added speculation for the decrease in overall number of viewers is that since all the programs had previously been shown, interest in the series declined when these same programs were "re-run."

Another slightly different example involves a comparison of "The Ernie Kovacs Show" (Table 10), presented at different evening hours, and on different days of the week.

Both the rating and viewers-per-100-homes data were much less for the Tuesday evening program than for the Saturday presentation. For Instance, the Tuesday rating was 4, compared to 11 recorded for Saturday. This wide difference presumably could have been caused by several contributing factors:

(1) Early evening programs (8:30 FM) generally produce more audience response than late evening programs (10:30 FM). 
(2) The above, coupled with the fact that Saturday does not precede a schoolday, usually means a higher incldence of children under 13 in the audience.

TABIL 10

DISTRIBUTION OF VIEWERS BY AGE AND SEX TO "ERNIE KOVACS" WHEN TELECAST AT DIFFERENT HOURS OF THE DAY

AND ON DIFPERENT DAYS OF THE WEEK

(by average number of persons per 100 homes tuned to the program)

\begin{tabular}{|c|c|c|c|c|c|c|c|c|c|c|c|c|c|}
\hline Day of & & & Under & & 13. & 17 & 18. & -39 & 40 & plus & & ota & 18 \\
\hline Broadcast & Hour & $\mathbf{R}^{\mathbf{a}}$ & $\overrightarrow{\mathbf{M}}$ & $\bar{F}$ & $\overline{\mathbf{M}}$ & $\overline{\mathbf{F}}$ & $\mathbf{M}$ & $\vec{F}$ & $\mathbf{M}$ & $\mathbf{F}$ & $\overline{\mathbf{M}}$ & $\mathbf{F}$ & $\overline{\text { ALL }}$ \\
\hline Tuesday & $10: 30 \mathrm{PM}$ & (4) & 3 & 3 & 18 & 18 & 39 & 39 & 27 & 24 & 87 & 84 & 171 \\
\hline Saturday & $8: 30$ FM & (11) & 43 & 40 & 12 & 7 & 28 & 33 & 41 & 43 & 124 & 123 & 247 \\
\hline
\end{tabular}

average rating.

(3) The Tuesday night program started at the mid-way point of both programs on the competing networks, whereas the Saturday program started at the same time as the competition.

(4) The Saturday competition did not include program types consisting mainly of the comedy element; however, "Garry Moore" was among the Tuesday competition. While "Garry Moore" was chiefly of the General Varfety nature, the program nevertheless contained strong comedy segments throughout.

What happens when a first-run program is shifted from one evening to another? NBC's "Bonanza" exempliftes very well the effect that such a re-scheduling may have on the success or fallure of a program.

In December, 1959, ARB recorded an average rating of 19 for this program -- an hour-long Wegtern. The three-month ARB average for October, 
November and December, 1961, on the other hand, showed a remarkable rating Increase to 32 (see Table 11). What could have caused such a difference in program popularity? There were no substantial changes in program format, no new leading characters were added, etc.

\section{TABLE 11}

DISTRIBUTION OF VIEWERS BY AGE AND SEX TO "BONANZA" WHEN TELECAST AT DIFPERENT HOURS OP THE DAY AND ON DIFFERENT DAYS OF THE WEER

(by average number of persons per 100 homes tuned to the program)

\begin{tabular}{|c|c|c|c|c|c|c|c|c|c|c|c|c|}
\hline Day & & & Unde1 & r 13 & 13. & -17 & 18 & -39 & 40 plus & & Tota: & \\
\hline Broadcast & Hour & $\mathbf{R}^{\mathbf{a}}$ & $\mathbf{M}$ & $\mathbf{F}$ & $\mathbf{M}$ & $\mathbf{F}$ & $\mathbf{M}$ & $\mathbf{F}$ & $\bar{M}$ & $\mathbf{M}$ & $F$ & ALI \\
\hline Saturday & $7: 30 \mathrm{PM}$ & (19) & 46 & 46 & 20 & 13 & 42 & 43 & 4235 & 150 & 137 & 287 \\
\hline Sunday & 9:00 PM & (32) & 24 & 21 & 14 & 12 & 36 & 42 & 4548 & 119 & 123 & 242 \\
\hline
\end{tabular}

$a_{\text {Average rating. }}$

The sets-in-use levels for both 1959 and 1961, during the telecasts of "Bonanza," were within $6 \%$ of each other. 5 When "Bonanza" was carried In 1959 on Saturday evening, for instance, 62\% of all television sets in the country were viewing one of the three network programs offered between 7:30 and 8:30 PM. When "Bonanza" was carried Sunday evening from 9:00 to 10:00 PM, however, the sets-in-use tota1 was 68\%. While this may have been a contributing factor to the increased ratings for the program on Sunday evening, it certainly was not the sole factor. Undoubtedly the most prominent reason for the rating increase was

5 Sets-in-use can be described as the percent of all television homes with their sets turned on. In effect, this is the total of all ratings for a given time period. 
competitive programming. In December, 1959, "Bonanza" was opposite the seventh highest-rated program on television -- "Perry Mason." At the time, that program was credited with an average rating of 32 . "Bonanza's" other competitors were somewhat less spectacular -- "Dick clark" (rating of 14) and "High Road" (rating of 9) -- both half-hour programs on ABC. In 1961, however, the picture was a much different one. "Bonanza's" competition then was "Bus Stop," a newcomer to television on $A B C$, and "G.E. Theatre" and "Jack Benny," two half-hour programs on CBS. "Bus Stop" managed an average rating of 15, while "G.E. Theatre" recelved a 20 , and "Jack Benny" a 21.

While "G.E. Theatre" and "Jack Benny" were well-established and popular programs a few years ago, they have since apparently lost some of their appeal to the viewing audience. "Bus Stop," on the other hand, was possibly at a disadvantage from the very start, since (1) it was a newcomer to television, and (2) it was scheduled opposite relatively strong competition.

Another interesting supposition can be offered relative to the widespread popularity of "Bonanza." The 9:00 PM time pertod occupled by "Bonanza" in the fall of 1961 was previously filled by another alltime favorite -- "The Dinah Shore Chevy Show." It seems reasonable to assume that devoted viewers to the "Chevy Show" may possibly have been NBC-holdovers for this 9:00 to 10:00 PM time period, at least for the first week or two of the new fall season. Since these viewers apparently liked what they saw, they remained with "Bonanza" on a regular basis, thereby helping to make 1t a top-rated television program. 
Finally, "Car 54, Where Are You?" (NBC, 8:30 to 9:00 PM), with a 23 rating, provided an excellent lead-1n for "Bonanza." Such a rating suggests that a strong holdover audience may have helped "Bonanza" considerably.

It can reasonably be assumed that none of the foregoing hypotheses can singularly be credited with the tremendous success of "Bonanza" In its Sunday night position as opposed to Saturday night. Several of these factors had to work hand in hand in order to make this program one of the top-rated in the country.

What about the makeup of "Bonanza's" audience? How did it differ from Saturday to Sunday night? According to Table 11, even though the rating increased from 19 on Saturday, to 32 on Sunday, the number of persons per 100 viewing homes decreased when the change in schedule was made. There were 287 persons viewing the program in every 100 homes on Saturday, as opposed to 242 persons in the same number of homes on Sunday. A closer examination shows that this decrease can mainly be attributed to youngsters under 13 years old. The reason for the decrease apparently was twofold: first, Sunday was a pre-school night whereas Saturday was not; and second, the Sunday night time-period was somewhat later (9:00 FM) than Saturday night (7:30 PM).

It seems quite clear, then, that there are a multitude of possible reasons why audience characteristics varied from program to program. It $1 \mathrm{~s}$ one of the purposes of thds study to discuss these reasons. 


\section{Average Audience to A11 Program Types}

It is generally accepted that the amount of nighttime viewing far exceeds that of the daytime. The reasons for this wide variation have been discussed in detail previously in this study. A look at the actual data provided by thts report further strengthens other studies in this respect.

The average national rating, for instance, for an evening program was 17 . When an average was computed on the basis of daytime programming, however, the rating was only 7 .

Likewlse, the number of viewers per 100 homes was noticeably less during the daytime hours (161) than during the evening (209). Only in the case of youngsters (both sexes) under 13 years of age, did the daytime viewers-per-100-homes data exceed the nighttime data for specific age-sex groups.

\section{E. Average Audience to Specific Program Types}

Concert Muslc (nighttime). "The Telephone Hour," the only program represented in this category, recelved a rating of 21 . This was four points higher than the nighttime average of all programs combined. Such a figure is probably somewhat higher than one might expect, since "cultural" programs are generally considered to be low "audience-pullers."

"The Telephone Hour" attracted particularly both sexes over 40. In fact, $37 \%$ more men and women in this older age group watched Concert Music than watched the average nighttime program. Analyzing it another way, people in the "over 40" group contributed $61 \%$ of the total audience, 
or 119 viewers per 100 homes. Another $25 \%$ of the audience came from men and women, 18 to 39 years old, principally women. However, this age-sex group fell considerably short of the 18-to-39 "average audlence" for all nightime programs combined.

Children and teenagers were not in the Concert Music audience to any significant degree. In fact, they represented only $14 \%$ of all viewers to the program type.

In summary, then, it can be said that Concert Music programs (In this case, limited to "The Telephone Hour") attracted primarily men and women over 40 . Men and women, 18 to 39 , while viewing the program type to some extent, would only be considered a "secondary" audience. A11 other segments of the viewing audience, even though important to the total, would not be considered vital to the program's success.

Music Variety (nighttime). With an average rating of 27 , Music Varlety programs "topped" all other program types analyzed in this study, Insofar as general popularity is concerned. Wide vartations existed, however, between average ratings received by individual programs within the type. "Sing Along with Mitch," for Instance, attained the highest rating (33) of the four programs represented, while "Dinah Shore" recelved the lowest rating (21).

Like Concert Music, Music Varlety attracted predominantly the viewers in the sample who were 40 years of age and older, more spectf1cally women. "Lawrence Welk," for instance, had an average audience consisting of 73 women per 100 homes in this age category, which amounted to nearly $57 \%$ of all female viewers to the program. 
Little interest in Music Variety was shown by children under 13 years old; In addition, a slightly less-than-average audience was noted for both sexes, 13 to 39 . Undoubtedly, the reason for the small number of children in the audience can be attributed to the fact that most of these programs were presented at hours when the majority of youngsters under 13 were probably in bed. The starting time for all programs in the type was no earlier than 9:00 PM. In addition, only two programs ("Dinah Shore" and "Lawrence Welk") were telecast on non-pre-school nights.

An attempt to obtain audience composition data for an early evening Music Variety program telecast during a past season was unsuccessful. Several years ago, "Perry Como" was presented at 8:00 FM, Saturday evening, but since ARB's reporting approach was not so definitive then as it is now, meaningful comparisons could not be made. However, it is speculated that if such a breakdown had been avatlable, it would have shown a higher incidence of viewing in the "under 13 " category than in the sample cases of this study. The same thing may have held true in the case of teenagers.

However, the most Important element of the Music Variety program type would undoubtedly still remain "men and women over $40 . "$

Talent Varlety (daytime). Th1s type was represented by only one daytime program, that being "The Amateur Hour," hosted by Ted Mack. Overall, the program was "average" In popularity, so far as the total audience was concerned, oince it maintained a rating of 7 . For Sunday afternoon, this represented a relatively large audience. 
In considering total viewers per 100 homes, Talent Variety was found to be in the top daytime position. It had approximately $35 \%$ more viewers per 100 homes (217) than did the average daytime program measured (161).

With the exception of chIldren under 13, a11 age and sex categories were highly attracted to the type. Even in the case of children, there was a significantly high amount of viewing. Seventy-nine percent of those youngsters who normally viewed the average daytime program vlewed "The Amateur Hour."

Twice as many men over 40 , and nearly twice as many women over 40, watched the program as watched the average daytime show.

An extremely high incidence of men, 18 to 39 , was also noted. Even women in the same age category were attracted quite strongly to the type.

Apparent1y, Talent Variety programs, such as "The Amateur Hour," have a rather universal attraction. This may, in part, be due to the human interest element which is prevalent throughout the program, in the use of "ordinary people" competing for top honors. However, this can only be regarded as a speculation, since it was not a part of the measurement involved in the study at hand.

It would appear from this analysis that both men and women over 40 would have been the best prospects insofar as seling an Idea or a product was concerned. Since Geritol has been a regular sponsor of "The Amateur Hour" for a considerable length of time, and since the product is sold primarily to people "over $35, "$ the advertiser's cholce of the program apparently was a good one. 
Comedy Varlety (nighttime). With 17 rating points to 1 ts credit, Comedy Variety (represented by five programs) maintained an average national nighttime audience over the three months studied. "Red Skelton" gained the highest acceptance with a rating of 29 , while "Ernie Kovacs" received only an 8 , as shown in Table 12, below.

\section{TABLE 12}

DISTRIBUTION OF VIETERS BY AGE AND SEX TO COMEDY VARIEIY PROGRAMS (EVENING)

(by average number of persons per 100 homes tuned to the program)

\begin{tabular}{|c|c|c|c|c|c|c|c|c|c|c|c|c|}
\hline \multirow[b]{2}{*}{ Program Name } & \multirow{2}{*}{$\begin{array}{c}\text { Ave. } \\
\text { Rating }\end{array}$} & \multirow{2}{*}{\multicolumn{2}{|c|}{$\begin{array}{c}\text { Under } 13 \\
\mathrm{M}\end{array}$}} & \multicolumn{2}{|c|}{$13-17$} & \multicolumn{2}{|c|}{$18-39$} & \multirow{2}{*}{\multicolumn{2}{|c|}{$\frac{40 \text { plug }}{\mathrm{M} F}$}} & \multicolumn{3}{|c|}{ Totals } \\
\hline & & & & $\overline{\mathbf{M}}$ & $\mathbf{F}$ & $\overline{\mathbf{M}}$ & $\bar{F}$ & & & $\overline{\mathbf{M}}$ & $\bar{F}$ & $\overline{\mathrm{AIL}}$ \\
\hline $\begin{array}{r}\text { Average Audience } \\
\text { to A11 Programs }\end{array}$ & $(17)^{a}$ & 18 & 18 & 12 & 8 & 28 & 37 & 41 & 49 & 99 & 112 & 211 \\
\hline $\begin{array}{l}\text { Bob Newhart } \\
\text { Ernie Kovacs } \\
\text { Jack Benny } \\
\text { Red Skelton } \\
\text { Steve Allen }\end{array}$ & $\begin{array}{r}(14) \\
(8) \\
(21) \\
(29) \\
(12)\end{array}$ & $\begin{array}{r}5 \\
24 \\
7 \\
25 \\
28\end{array}$ & $\begin{array}{r}4 \\
22 \\
9 \\
26 \\
26\end{array}$ & $\begin{array}{r}8 \\
15 \\
8 \\
15 \\
13\end{array}$ & $\begin{array}{r}5 \\
12 \\
5 \\
11 \\
10\end{array}$ & $\begin{array}{l}34 \\
32 \\
23 \\
25 \\
36\end{array}$ & $\begin{array}{l}45 \\
36 \\
31 \\
36 \\
40\end{array}$ & $\begin{array}{l}32 \\
34 \\
50 \\
44 \\
33\end{array}$ & $\begin{array}{l}43 \\
34 \\
64 \\
50 \\
38\end{array}$ & $\begin{array}{r}79 \\
105 \\
88 \\
109 \\
110\end{array}$ & $\begin{array}{r}97 \\
104 \\
109 \\
123 \\
114\end{array}$ & $\begin{array}{l}176 \\
209 \\
197 \\
232 \\
224\end{array}$ \\
\hline
\end{tabular}

a Weighted according to ratings received by programs within type.

Since these programs were widely dissimilar in format, master of ceremonies, etc., It is necessary to discuss each individually, because the audience to each was radically different. The above table points thls out quite vividly. "Bob Newhart" and "Jack Benny," for instance, apparently did not appeal to elther teenagers or younger children to anywhere near the degree that "Ernie Kovacs," "Red Skelton" and "Steve Allen" appealed to them. "Bob Newhart" and "Jack Benny" both were at a disadvantage, though, to begin with, since both were consistently telecast at a later evening hour than the other three programs. Neverthe- 
less, "Red Skelton" was also presented at a late hour (9:00 to 9:30 PM, Tuesday), and yet his audience was composed of 77 persons per 100 viewIng homes who were 17 years of age or younger. "Red Skelton," by the way, had more viewers per home $(2.32)^{6}$ than any of the other Comedy Variety programs. In fact, a reference to Tables 7 and 8 indicates that only in the case of children's programs does the viewers-per-home figure ever surpass this level for any given type.

Except for late evening telecast time, what other reasons were there for the unpopularity of "Bob Newhart" and "Jack Benny" among the younger viewers? Probably the type of comedy had something to do with it. Both Newhart and Benny are sophistlcated comedians, dealing more with "straight" comedy, and leaving Kovacs, Skelton and Allen in the "slapstick" roles. Allen is certainly less "slapstick" than Kovacs or Skelton, but nevertheless, it would seem that the type of humor he presents might be more appealing to youngsters than that of either Newhart or Benny .

It is rather doubtful, on the other hand, whether or not the younger viewers fully apprectated the type of humor presented by "Ernie Kovacs," even though they watched him. He was a master showman, but sometimes it is wondered if he was understood well enough to be fully appreciated. Many of his asides were directed to television production, for instance, and probably were lost by the majority of viewers (even in the older age-sex groups).

6 This is another way of expressing total viewers. The same figure can be transposed into "viewers per 100 homes" simply by dropping the decimal point. 
Both "Bob Newhart" and "Steve Allen" were overwhelmingly viewed by men and women in the 18 to 39 age group. Viewers in this category, however, also found the other three programs attractive enough to watch. The "Jack Benny" audience was the sma1lest in the 18-to-39 agesex category of all five programs analyzed.

Whatever audience "Jack Benny" may have 1ost in the 18-to-39 area, however, was regained in another. Vlewers 40 years and older totaled 114 per 100 homes. In fact, this older age group represented nearly $58 \%$ of the entire audience to the program.

"Red Skelton," as well as being a favorite with the youngsters, also was a favorite with the oldsters. Th1s program was viewed by 94 people in every 100 homes who were 40 years of age and older. Unlike most programs, "Red Skelton" attracted all age groups to a far greater degree than one might imagine.

In fact, the analysis of the Comedy Varlety program type seems to bear out the old adage that "comedy has a universal appeal."

General Varlety (daytime). Art Linkletter's "House Party" was the only daytime program falling into the General Variety category during the three-month period of this study. Again, as in most other Monday-through-Friday programs, a very sma1l male audience viewed the show. In fact, except for Women's Serials and General Drama, General Varlety recelved the lowest "per 100 homes" figure for total daytime male viewers, it being a mere 33 .

"House Party" seemed to gain the largest single segment of its audience from women past 40 . In fact, this group represented nearly $44 \%$ 
of the program's total viewers, Women from 18 to 39 also contributed a falr share to the overall audience -- another 23\%. This left a final 33\% to be divided among all other age and sex categorles. To say that this program type appealed primarily to the housewife seems to be an understatement.

In terms of total audience, ARB estimated that the average "House Party" program was viewed by $7 \%$ of all U.S. television homes.

Genera1 Varlety (nfghttime). Like Comedy Varlety, programs such as "Ed Sullivan" and "Garry Moore" apparently had a very general appeal to almost everyone. Except for children under 13 (and these low figures undoubtedly were due in part to late evening presentations on pre-schooldays), all age categories viewed General Variety to about the same degree as viewed the average evening program represented by all types combined. Men and women past 40 made up approximately $47 \%$ of the average program's audience, with women having the customary lead.

Rating-wise, General Variety programs were in second place in nighttime television. With an average rating of 26 , this type was surpassed only by Music Variety, which managed an average rating of 27.

Even though "Ed Sullivan" has been on the afr for over fourteen years, the program still is a gigantic drawing card every Sunday at 8:00 PM. It is interesting to note that Sullivan managed an average rating of 31 during the three months studied. This represents an audience $82 \%$ greater (in terms of number of homes) than the average audience to nighttime television considered as a single unit.

Because of its extremely flexible format, plus its late evening 
telecast time, "Jack Paar" was not included in the foregoing averages for nighttime General Variety programs.

The total number of viewers per 100 homes (155) to "Jack Paar" was far less than the average nighttime program (209), and slightly less than the average for daytime programs (161). This, of course, was undoubtedly due to the late hour of the telecast.

The number of viewers under 18 was negligible ( $3 \%$ of the total audience), which is not difficult to understand.

Women over 18 seemed to dominate the "Jack Paar" program in numbers. They consisted of 90 viewers per 100 homes, amounting to $58 \%$ of the entire audience to the program. Men over 18, of course, then contributed the remaining $39 \%$ to the total figure.

For a late evening program such as this, it would seem that the rating of 7 which it recelved, would be considered "more than adequate" from an advertiser's point of view.

General Drama (half-hour daytime). Both programs which were included in the daytime General Drama category were "re-runs" from previous seasons ("The Militonaire" and "Loretta Young"). Since these two programs were telecast during the mid-afternoon hours, at about the same time as most Women's Serials, it is easy to see why the number of viewers per 100 homes (131) might closely approximate that of the Serials (128). The average ratings for both were approximately the same, too. General Drama recelved a rating of 6 , while Women's Serials recelved a 7 .

The only audience of any real consequence to daytime General Dra- 
ma consisted of women over 18 . In fact, there was little difference in the overall number of viewers in the middle and older age categories. Women 18 to 39 viewed at the rate of 46 persons per 100 homes, while women 40 and over viewed at the rate of 42 persons per 100 homes.

General Drama (half-hour and hour, nighttime). The differences found between half-hour and hour dramatic programs (nighttime) were these:

(1) Ratings were slightly higher (21) for hour-long programs than for half-hour programs (19). The difference, however, seems relatively insignificant, since it was so small.

(2) Children under 13 , both sexes, were less receptive to the average hour-long program than to the half-hour program. This might be related to the fact that, generally speaking, hour-long presentations are directed more specifically to the adult mind. In addition to this, the average youngster probably finds it difficult to sit still for such a long period of time.

(3) Both men and women viewers, 18 to 39 , were attracted more to the one-hour drama than to the half-hour drama.

(4) A reversal of this attraction appeared, however, in older viewers. Both men and women, 40 and over, tended to view the half-hour dramatic program to a greater degree than the hour program.

(5) There were slightly more viewers per 100 homes to half-hour dramas than to hour dramas. However, as in (1) above, the difference is probably insignificant. 
Speaking in terms of all nighttime dramatic programs, the largest contribution of viewers came from the older age group (past 40). However, a General Drama sponsor would have had a potentially good audience for any product normally bought by adults over 18 years of age.

\section{Situation Comedy (daytime) . Situation Comedy, Iike General} Drama, recelved an average rating of 6 for daytime programs. However, the audience makeup was extremely different. There were 1.74 persons per TV home tuned to the average situation Comedy program. This 1s relatively high for daytime programing. The reason for this seems to be related to the younger age group, under 13 years of age. Thirty-nine girls viewed situation Comedies per 100 homes, while 52 boys also viewed. The viewers in this age category alone amounted to $52 \%$ of the average program's total audience.

Little viewing was credited to men over 18 years old (14 persons per 100 homes).

Women over 18 , on the other hand, totaled $30 \%$ of the average audience to Situation Comedy programs.

Situation Comedy (nighttime). Evening viewing to situation Comedy was far different from daytime viewing to the same type. The average rating in the evening, for instance, was 20 . This 18 three rating points higher than the average for all evening programs comblned. Children under 13 made up a gizeable portion of the audience (28\%), even though this group showed a significant drop from daytime viewing. This overall decrease in viewers per 100 homes apparently was due, In part, to late eventing scheduling of several of the programs. 
As would be expected, there was a decided increase in male viewers over 18 years old, as compared to the daytime situation Comedy audience. In fact, the evening adult male audience to situation comedy was roughly four times greater than the daytime adult male audience to the same program type.

There was also a significant nighttime increase of women viewers In the 18-to-39 age bracket. More noticeable, however, was the nearly twofold increase of women over 40 .

Overall, it can be said that Situation Comedy was highly attractive to all segments of the available audience. Most advertisers would have found a receptive audience for their products (in relation to age and sex, at least) if they had sponsored the average Situation Comedy represented in this study.

With the posstble exception of nighttime Children's Drama, however, there were probably no program types which could have offered a better audience for products almed primarily at children and teenagers (in terms of ratings as well as viewers per 100 homes).

Suspense Drama (nighttime). With an average rating of 18 to its credit, Suspense Drama clalmed an above-average number of homes for nighttime television. Actual viewing within homes, however, was somewhat less to Suspense Drama ( 1.95 viewers per home) than to the average nighttime program (2.09 viewers per home). The absence of chlldren under 13 helped contribute the most to this low viewers-per-home figure. Al1 remainting age and sex groups stayed quite stable in numbers as compared with the average evening audience to all types comblned. 
The overall audience makeup of Suspense Drama was very simflar to that of Action Adventure and Crime Detective, except for a significantly higher Incidence of children under 13 in the Action Adventure audience. Th18, again, was probably due, in part, to early versus late eventng program scheduling.

Action Adventure (nighttime). As stated above, with the exception of an increase in younger viewers (both sexes under 13), the audience composition of this program type was almost identical to that of Suspense Drama.

Action Adventure programs seemed to have a slightly-less-thanaverage attraction for the older audience ( 40 plus), but an aboveaverage attraction for the middle age group (18 to 39).

In comparing program popularity, however, the average rating for Action Adventure was slightly lower (16) than for Suspense Drama (18); however, this would not seem to be too significant.

Crime Detective (nighttime). A very slight increase in both male and female viewers past 40 was found in comparison with both Suspense Drama and Action Adventure.

Children under 13 viewed at approximately the same rate as they viewed Suspense Drama, while both men and women, 18 to 39 , viewed at exactly the same rate as to Suspense Drama.

The average rating, too, was Identical to Suspense Drama, it being 18 .

So far as age and sex relationships are concerned, this program type seemed to attract basically the same audience as Suspense Drama. 
Hesterns (daytime). As was discussed previously, the average daytime Western program (in this case, "The Texan") was able to maintain a rating of only 2 . This, by the way, was the lowest-rated program type on the air (daytime or nighttime) during the entire period under study.

One of the most significant audience segments viewing the type was the "under 13 " group (both male and female). A total of 44 children per 100 homes watched daytime Westerns. This represented $32 \%$ of al1 viewers to the program type.

Practically no teenagers and relatively few men over 18 were in the audience.

Women over 18 , however, made up $47 \%$ of the total viewers. Children under 13 and women over 18, then, were the two most important segments of the daytime Western audience. Again, it should be pointed out, though, that only one program was included in this type. If more programs had been telecast, the audience composition data might have looked somewhat different.

Westerns (nlghttime). According to the data collected from this study, $21 \%$ of all television sets in the United States were tuned to the average nighttime Western. This represents an increase of four rating points over the average rating of all nighttime programs combined.

Nighttime Westerns seemed to attract more male viewers in all age categories than did the average evening program. Female viewers, at the same time, tended to watch Westerns to about the same degree as they watched the average evening program.

Sixty-two percent of the audience was composed of youngsters under 13, and, men and women over 40 . 
It is Interesting to note that this was one of the few program types where men over 40 elther equalled or surpassed women in the same age category, In terms of viewers per 100 homes. In this case, each sex contributed 47 viewers to the total of 223 viewers per 100 homes.

Even though Westerns are now on a downward trend, apparently they still are a key attraction for all age and sex categories, at least if the results of this study can be considered indicative of viewing habits during other months of the year.

Women's Serials (daytime). The nine programg included in this program type varled in individual ratings from 5 to 12 . However, the average rating for the programs taken as a group was 7 .

In terms of viewers per 100 homes, Women's Serials had the lowest total of any program type included in the study. This is probably due to the fact that the programs were almed specifically at a certaln segment of the viewing audience; namely, women over 18 years of age.

Are Women's Serials doing an effective job fōr the advertisers who sponsor them? In terms of age and sex, the advertiser probably could not have reached so many potentially receptive viewers as he did with this program type. Seventy-seven percent of the total audience to Women's Serials consisted of women over 18. This amounted to 99 viewers per 100 homes, which was the highest figure ever attained in this study for this particular age-sex bracket.

Feature F1lms (nighttime). Only one program was represented in the Feature Film classification -- "Saturday Night at the Movies," a two-hour program presented by NBC. 
Only two other program types (Music Variety and General Variety) surpassed Feature Films in average ratings recelved over the three-month period under study. Feature Films, with an average rating of 22 , reached approximately $10,869,000$ television homes $1 n^{\prime}$ the United States during an average telecast.

Even with its late evening telecast time (9:00 to 11:00 PM), "Saturday Night at the Movies" reached a relatively large "under 13" audience ( 39 viewers per 100 homes). Once again, however, since Saturday does not precede a school-day, these youngsters apparently were allowed to stay up later than their normal bedtime hour.

Looking at total viewers per 100 homes, Feature Films again was surpassed by only two other program types (in this case, Children's Drama and Cartoon Comedy).

Like all types of drama, teenagers of both sexes tended to view Feature Films to about the same degree, each sex contributing 11 viewers per 100 homes.

This program type was particularly attractive to both men and women, 18 to 39 . Slightly more than $38 \%$ of the total Feature Films audience consisted of viewers from this age category.

In terms of the average audience to all evening programs combined, there was a slight increase (statistically not significant, however) In men viewers over 40 . Women viewers of this age bracket, however, found this program type the least attractive of all dramatic types established for this study. 
Audience Participation (daytime). The biggest program-type contributor, in terms of number of different programs on the alr during the daytime, was Audience Participation. During the three-month period of this study, there were seventeen different Audience Participation programs on the air from sign-on to 6:00 PM. This was nearly twice the number of programs contributed by any other type. 7

In many ways, Audience Participation programs attracted an audience very similar to that of Women's Serials, except that the overall number of viewing homes was less for Audience Participation. This can readily be seen by comparing the ratings of both types. Women's Serials, with an average rating of 7 , surpassed the average Audience Participation program by three rating points, since the average rating for the latter type was only 4 .

Women over 40 viewed Audience Participation programs to the same degree as they viewed Serials. However, women, 18 to 39 , even though finding the programs in this type above-average in attractiveness, nevertheless watched Women's Serials significantly more.

All other age and sex categories, while contributing more viewers per 100 homes to Audience Particlpation than to Women's Serials, nevertheless played minor roles in the total audience picture. "Men over 40" probably was the most significant "other" age-sex group, contributing 18 viewers per 100 homes.

7 Women's Serials and Sports Events each consisted of nine different programs. However, since Sports Events were "one-time-only" programs, that type should be considered in a somewhat different light. 
One program ("video Village, Jr."), which would normally have been defined as Audience Participation, was not Included in the totals heretofore reviewed. Since "Video Village, Jr." was aimed primarily at youngsters, its audience composition characteristics would be expected to be quite different from the adult programs in the same type.

Seventy-elght percent of the total audience to this program was composed of boys and girls under 13, with no significant differences in viewing levels between the two sexes. Thls left $22 \%$ of the audience to be divided among the remaining six age-sex combinations.

It would appear from these figures that "Video Village, Jr." did an excellent job of attracting the specific segment of the audience it was after.

Audience Participation (nighttime). The two programs included in this classification ("The Prlce Is Right" and "Yours for a Song") maintained a combination average rating of 16 , slightly less than the 17 average rating for all nighttime programs combined.

The following audience composition differences were noted between the daytime and nighttime versions of Audience Participation programs (in terms of viewers per 100 homes):

(1) Nighttime viewing increased for children under 13 by $30 \%$.

(2) Nighttime viewing increased for teenagers by $160 \%$.

(3) Nighttime viewing increased for men, 18 to 39 , by $300 \%$.

(4) Nighttime viewing increased for men over 40 by $150 \%$.

(5) Nighttime viewing Increased for women over 40 by $19 \%$.

(6) Nighttime viewing remalned quite constant for women, 18 to 39 . 
The above amounted to an overall increase from 141 viewers per 100 homes (daytime) to 208 viewers per 100 homes (nighttime).

This program type (nighttime version) apparently was a particular favorite of both sexes over 40 years of age. The total viewing per 100 homes in this age-sex category was 237 greater than the nighttime average of all programs combined.

Al1 other age-sex categories dropped in total number of viewers per 100 homes when making simflar comparisons.

Game Panel (nighttime). In terms of sheer numbers, Game Panel programs did somewhat better (rating of 21) than Audience Participation programs (rating of 16 ).

However, in terms of audience makeup, there was very little difference between the two program types.

An examination of Table 8 reveals only one really significant difference in all age and sex brackets studied. This occurred in children under 13, where a "drop off" was experienced when comparing Audience Participation (35 viewers per 100 homes) with Game Panel (20 viewers per 100 homes).

Al1 other age-sex categories were almost identical for both program types.

Quiz Panel (daytime). Only one program was represented in this program type -- "G.E. College Bowl." Over the three-month perlod under study, this program maintained an average rating of 10 , which is relatively good considering (1) that it was telecast on Sunday afternoon, and (2) that its format was strictly "academic" in nature. 
In respect to total viewers per 100 homes, only one other daytime program surpassed Quiz Panel (203), that being Talent Variety (217). The reason for these high figures seems quite evident, in that all programs represented were telecast Sunday afternoon, when more members of the average family were hypothetically "avallable" for television viewIng than during the average Monday-through-Friday afternoon.

Chtldren under 13, while attracted to Quiz Panel programs to some degree, would not be considered an extremely important element of their audience makeup, since many other program types tended to attract this age-sex group considerably more.

Teenagers, on the other hand, apparently found the program quite attractive. To illustrate, exactly twice as many persons in this category (both sexes combined) watched "G.E. College Bow1" as watched the average daytime program.

Similar increases over the "daytime average" were noted throughout all remaining age-sex brackets. The most dramatic of these were:

(1) an increase of $50 \%$ for men, 18 to 39 ,

(2) an increase of $100 \%$ for men over 40 , and

(3) an increase of $78 \%$ for women over 40 .

News (nighttime). As might be expected, "low level" viewing was noted throughout the News programs analyzed. With six nighttime News shows represented, the average rating computed was 8 , slightly less than half the rating of the average nighttime program. Only two nighttime program types (Public Affairs and Sports Events) recorded lower total numbers of viewers per 100 homes than News. 
Apparently the most important segment of the audience -- the one which was attracted most to News -- was the "40 plus" bracket. Both sexes comblned, in this category, contributed 109 of the total of 177 viewers per 100 homes. Th1s represented $62 \%$ of the entire audience. Women, again, were in the audience to a greater degree than were men. Both men and women, 18 to 39 , made less-than-average contributions to News ( 49 viewers per 100 homes). Even so, this age-sex group was important to the overall audience, since it contributed another $28 \%$ to the total figure.

Public Affairs (daytime and nighttime) . For all practical purposes, there was no significant difference in audience composition between daytime and nighttime Public Affairs programs. This probably was due, In part, to the fact that the only daytime Public Affairs program represented was "Chet Huntley," telecast late Sunday afternoon, when a "simflar" audience to nighttime programs was probably "available" for viewing.

Rating-wise, daytime Public Affairs programs recelved a 6 , while the nighttime programs received a 7 .

The following analysis was true of both daytime and nighttime programs:

(1) The majority of the audience came from the viewing population over 40 , malnly women.

(2) The secondary audience segment was the group, 18 to 39 , there being no significant difference in viewing habits between men and women. 
(3) The amount of viewing by children and teenagers was negligible.

Overall, the viewing pattern of Public Affairs was very similar to that of News.

Two programs, because of their nature, should be discussed separately. These are "David Brinkley's Journal" and "Today."

Both of these programs, whtle having certain Public Affairs elements, cannot be considered in exactly the same light as the programs included In the Public Affairs averages, as Iisted in Chapter III.

"David Brinkley"s Journal" seemed to have more of an "gveräge program attraction" than did Public Affairs programs in general, although the percent of youngsters and teenagers in the Brinkley audience was much less than in the Public Affatrs audience.

More men and women, 18 to 39 , and less men and women over 40 , were attracted to Brinkley than they were attracted to Public Affairs programs in general.

"Today," on the other hand, had a tremendous "over 40" audience, considering that the program was on early in the morning (7:00 to 9:00 AM). Women over 40 viewed at the rate of 70 viewers per 100 homes -the highest incidence recorded for this age-sex category. This represented $39 \%$ of the total audience to the program. Another 41 viewers per 100 homes were men over 40 .

Women, 18 to 39 , contributed 26 viewers per 100 homes, while men In the same age group contributed only half that number. Teenagers recorded "about average" viewing to the program, while the viewing done by children under 13 was negligible. 
Insofar as ratings are concerned, "David Brlnkley's Journal" recelved an 1I, whlle "Today" recelved a 5.

Documentary (nighttime). Unlike News and Public Affairs programs, Documentarles were found somewhat attractlve to children under 13 years old. Other slight Increases in this program type over News and Public Affairs were noted in teenagers (both sexes), and in both men and women, 18 to 39 .

On the other hand, people in the older age-sex category (40 plus) found this program type somewhat less attractive than News and Public Affairs.

The reason for the small increase in viewers per 100 homes, and the relatively large Increase in ratings, may be due, in part, to the fact that most Documentaries are presented in a somewhat more palatable manner (for younger people, in particular) than are "straight talks" programs. In some cases, such as "Circle Theatre," everything is presented in dramatic form, so that one is entertained at the same time he is being informed.

The overall total audience for the average Documentary was also somewhat larger than for News and Public Affairs, since it recelved a rating of 15 .

Sports Events (daytime). As would be expected in the analysis of this program type, very pronounced sex differences existed in the audience composition data.

In all age-sex categories, the male audience was over twice as great as the female audience, in terms of number of viewers per 100 
homes. In fact, the overall average audience was composed of $74 \%$ males and $26 \%$ females.

In the 18 to 39 age category, more men per 100 homes (39) vlewed Sports Events than viewed any other program type in the study.

Only one other program type (Public Affairs) gained as many viewers per 100 homes (51) for men over 40 years of age.

With the exception of Teenage Dance, which rated 16 viewers per 100 homes, boys 13 to 17 were attracted to Sports Events more than to any other program type (12 viewers per 100 homes).

The average rating for the nine Sports Events programs under study was 10 . This was three rating points higher than the daytime average rating of 7 for all programs combined.

Sports Events (nighttime). As in the case of daytime Sports Events, the audience to nighttime Sports Events was quite heavily welghted toward the male in relation to actual numbers of viewers per average program. However, the following differences between daytime and nighttime audiences existed:

(1) More women were attracted to nighttime Sports Events programs (37\% of total audience) than to daytime (26\% of total audience). This may have been due, in part, to the fact that the type of Sports Events differed -- daytime being composed of basketball, football and golf, and nighttime being composed of boxing and bowling.

(2) There was a decided Increase in number of nighttime male viewers in the "under 18 " category, which was probably due 
to the fact that nighttime programs were telecast at a late hour.

(3) Male viewers, 18 to 39 , decreased substantially in numbers for the evening programs, from 39 to 21 viewers per 100 homes .

(4) A very significant nighttime increase occurred, on the other hand, in number of viewers for both sexes over 40. Men increased from 51 to 71 viewers per 100 homes, while women made a similar jump from 20 to 43 viewers per 100 homes.

Ratings, however, remained the same for both daytime and nighttime programs -- 10 .

Chlldren's Drama (daytime). All programs included in this category were telecast on Saturday morning or early afternoon when, hypothet1cally, more children are "avatlable" for vfewing. Therefore, it was no shock to find that $69 \%$ of the total audience to this program type was composed of children under 13 years of age. This represents a total of 135 viewers per 100 homes, or an average of 1.35 viewers per home.

Teenagers contributed another 19 viewers per 100 homes, which is relatively high for this age group, considering that the "average audience" for teenagers during the daytime amounted to only 11 viewers per 100 homes.

More women than men (over 18) viewed daytime Children's Drama, but neither sex in these older age categories would be considered a "strong" element in the overall totals of the program type. 
A rating of 9 was recorded as the average for all daytime Children's Drama programs combined.

Children's Drama (nlghttime). The overall audience composition plcture changed somewhat when comparisons were made between daytime and nighttime Children's Drama programs. The major differences were these:

(1) Whereas daytime programs in this category maintained an average rating of 9 , the nighttime programs maintained a 19 rating *

(2) The total number of viewers per 100 homes increased from daytime to nighttime from 196 to 250 . This latter total, by the way, represents the highest viewers-per-100-homes figure attained by any program type in the entire study.

(3) Even though the number of nighttime viewers per 100 homes In the "under 13" age classtfication was still relatively large (110), these viewers represented only $44 \%$ of the entIre audience to the programs.

(4) In terms of viewers per 100 homes, teenagers remained practically constant in numbers from daytime to nighttime programs.

(5) Difference $\$ 3$, above, was due, in part, to a substantial increase in men and women viewers over 18 years of age. For Instance, men contributed $20 \%$ to the total audience, while women contributed another $28 \%$.

Children's Variety (daytime). With an average rating of 11 , Children's Varlety programs recelved the highest audience of any daytime program type in the ent1re study. 
Of the 184 viewers per 100 homes found viewing the programs, 157 were children under 13.

The teenage audience to Children's Variety was almost negligible. As might be expected, more women than men were attracted to the programs, although nelther sex contributed a significant number of viewers to the overa11 total audience.

One program ("Mr. Wizard") which probably would be considered as Chlldren's Varlety under ordinary clrcumstances, was not included in the totals of the preceding analysis. It was felt by the writer that "Mr. Wizard" was aimed primarily at a more mature mind than "Captain Kangaroo" and "Shari Lewis," for instance; therefore, it should be discussed separately.

While youngsters under 13 (primarily boys) were attracted to "Mr. Wizard," this attraction in no way paralleled that found for "Captain Kangaroo," "Shari Lewis," "Magic Land of Allakazam" and "Pip the Piper."

In comparing teenagers, however, it was found that, while the average number of viewers per 100 homes to the four Children's Variety programs just mentioned was only 5 , it was 36 for "Mr. Wizard." Of this total, 28 viewers were males.

It is interesting to note that, in the younger age groups, more males than females were attracted to "Mr. Wizard." However, in the "over $18^{\text {"t }}$ classiffcation, the attraction was just the opposite. Thirty viewers per 100 homes were men over 18, while 45 viewers were women. With an average rating of only 2, "Mr. Wizard" would not be considered a particularly popular program. 
Children's Variety (nighttime). Only one nighttime Children's Variety program ("1,2,3 - Go") was telecast by the networks during the three months under study.

This particular program, even though it supposedly was afmed at the younger viewer, attracted many viewers in the older age categories. The largest segment of the "1,2,3 - Go" audience (41\%) consisted of men and women over 40 .

Children under 13 contributed the next highest percentage of total viewers (32\%).

Another $20 \%$ came from the 18 to 39 age category, while the final $7 \%$ was credited to the teenage audience.

The rating of 4 which $" 1,2,3$ - Go" received is reason enough why NBC decided to replace the program in the fall of 1962.

Gartoon Comedy (daytime). Of all the program types studied in this report, no single age-sex category equalled the high number of viewers per 100 homes recorded by children under 13 for daytime Cartoon Comedy. This figure of 163 represented $86 \%$ of the grand total of 189 viewers per 100 homes.

Eleven viewers per 100 homes were found to be teenagers, while the remaining 15 viewers per 100 homes were all persons over 18 years of age.

Cartoon Comedy's daytime rating of 9 was slightly higher than that of the average daytime program, which was 7 .

Cartoon Comedy (nighttime). While the "under 13" audience was st11I extremely high for nighttime Cartoon Comedy programs (138 viewers 
per 100 homes), it was accompanied by a very substantial increase in older viewers.

Thirty-three percent more teenage boys, for instance, were attracted to nighttime Cartoon Comedy than to the average nighttime program. Teenage girls, on the other hand, were attracted exactly to the same extent as to the average nighttime program.

The remainder of the viewing audience (36\%) was composed of persons over 18 years of age. It 1 s doubtful that any really significant differences existed between men and women in relation to each one's attraction to the type.

The average nighttime rating of 13, while being somewhat larger than the daytime rating, was stil four points less than the overall nighttime average.

Teenage Dance (daytime). This program type, by far, was the greatest attraction to teenagers of all programs studied, both day and night. Within the 13 to 17 age group, males viewed at the rate of 16 persons per 100 homes, while females viewed at the rate of 36 persons per 100 homes. Even though this total represented only $27 \%$ of the entire audience, the important point to consider is that this was the most effective program type on the air in terms of reaching specifically the teenage segment of the audience.

Children under 13 represented $29 \%$ of the total audience, with little difference noted in viewing levels between boys and girls. Women over 18 , however, made up $31 \%$ of the remaining portion of 
the Teenage Dance audience, while their male counterparts contributed only $13 \%$ to the total figure.

The slightly above-average daytime rating of 8 should indicate to an advertiser interested in reaching the teenage audience, that Teenage Dance programs, at least in this case, probably did an effective job of reaching their prospective "clients."

$$
\text { F. In Summary }
$$

Assuming that the results of this study are indicative of TVviewing in general, this chapter illustrates quite conclusively that marked dissimilarities exist in the viewing behavior of persons of different age and sex characteristics.

It becomes quite apparent that certain elements within program types tend to attract specific age and sex groups to those types. At the same time, however, it should be remembered that programs within certain types often vary considerably insofar as general appeal is concerned.

In addition, widespread differences in viewing behavior can be expected due to such things as program scheduling (daytime versus nighttime; weekday versus weekend) and program competition.

A11 of these criteria must be taken into consideration and studied thoroughly if one is to fully understand the television viewing audience. 
THE RELATIONSHIP OF PROGRAM-TYPE APPEAL TO THE EDUCATION OF THE VIEWER

It seems reasonable to assume that there is a fairly close relationship, In most cases, between education and buying power. Undoubtedly this relationship also extends to the quality or types of consumer goods purchased. With this in mind, then, the thoughtful television advertiser is generally interested in the educational background of the people who buy his product. Such information perhaps is more valuable to some advertisers than it is to others. For instance, the average producer of foodstuffs probably is not so aware of the education of his customers as is the manufacturer of automobiles. On the other hand, if specific foodstuffs are in the "dellcacy" line, then education conceivably would become a very important element.

Many advertisers perform Intricate research projects to determine the types of people who purchase their varlous products. With this information, they try to match their findings with the most suitable "vehicles" within the advertising media. In the study presented here, a "vehicle" would, of course, be an individual television program.

\section{A. Education of Adult Television Viewers}

What is the educational attainment of adult television viewers in the United States? In order to determine the answer to this question, al1 data concerning education complled for the three-month period of the study were averaged, weighting each program according to the rating it 
received. The results are shown In Table 13, along with total sample distribution of all ARB diarles during the three-month period, in relation to education. Because the avallable data were restricted to "heads of households" and "housewives," then of course all results are also in these terms.

TABLE 13

COMPARISON OF TOTAL SAMPLE DISTRIBUTION WITH TOTAL VIEWING CHARACTERISTICS OF HEADS OF HOUSEHOLDS AND HOUSEWIVES BY EDUCATIONAL BACKGROUND (by percent of persons within each education category)

Total Sample Actual viewing
Category

Head of Household

Under 9 years of school completed

9 to 12 years of school completed

13 and more years of school completed

Totals

\begin{tabular}{ll}
$16.0 \%$ & $19.0 \%$ \\
51.0 & 52.0 \\
33.0 & 29.0 \\
\hline $100.0 \%$ & $100.0 \%$
\end{tabular}

\section{Housewife}

Under 9 years of school completed

9 to 12 years of school completed

\begin{tabular}{ll}
$10.0 \%$ & $11.0 \%$ \\
62.0 & 64.0 \\
28.0 & 25.0 \\
\hline $100.0 \%$ & $100.0 \%$
\end{tabular}

Totals

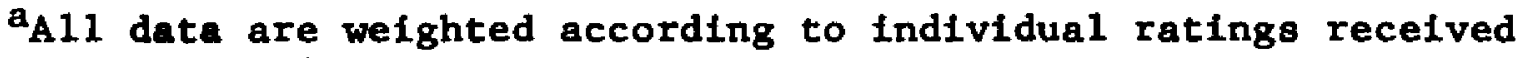
by the programs included in the study.

To make the data in Table 13 more meaningful, it is necessary to study next the overall picture of educational attainment in the United States taken as a whole. Since the Bureau of the Census did not estabIish basic classifications agreeing with those of the American Research Bureau, the Census data could not be included in Table 13, above. Therefore, these data are presented in Table 14, and are based on the ent1re 
population of the United States (25 years old and over). Hypothetically the Census distribution of population according to education (Table 14) should agree substantially with the ARB total sample distribution (Table 13). Such a comparison, however, shows that the data do not compare favorably.

TABLE 14

DISTRIBUTION OF U.S. POPULATION ACCORDING TO EDUCATION 1

(by percent of persons 25 years old and over falling within each education category)

Under 9 years of school completed $39.7 \%$

9 to 12 years of school completed 43.8

13 and more years of school completed 16.5

Total $\quad 100.0 \%$

There are several contributing factors to the differences found in the two tables. These factors are:

(1) The Census data are based only on persons 25 years of age and older, whereas ARB's data are in terms of "head of household" and "housewife," regardless of age.

(2) The Census data include many "unattached" persons not living in a so-called "household." These persons are not Included in ARB's sample.

1 U.S. Bureau of the Census, U.S. Census of Population: 1960. Genera1 Social and Economic Charactertstics, Untted States Summary. Final Report PC(1)-1C (U.S. Government Printing Office, Washington, D.C., 1962), p. 1-207. 
(3) ARB's sample tends to be concentrated in the more populated areas of the country by virtue of the sampling technique it employs. According to the 1960 Census figures, the percent of people living in urban areas who completed thirteen or more years of school was 18.6. This was $2.1 \%$ higher than the overall average of $16.5 \%$, as reported in Table $14 .^{2}$

(4) It is possible that people with more education tend to return diaries at a greater rate than people with less education.

(5) The Census data include non-telephone and non-television owning homes, whereas the ARB data are restricted to telephone and television owning homes.

(6) ARB's diary keepers may tend to exaggerate their educational backgroumd when filling out a diary as opposed to answering the same questions asked by a Census taker.

Only Factors 1 and 2 justify the wide variation in data. The remaining factors merely suggest "reasons" for the high incidence of college-trained people in the ARB sample. Keeping these factors in mind, the writer will concede that ARB's sample probably includes more people who fall in the upper education brackets than actually exists in the universe; since no Census data are avallable, however, which are entirely comparable to ARB's data, it is impossible at this time to determine the extent of the differences.

Even though the distribution of ARB's sample by education may not

2 Ibid., p. 1-208. 
have been in direct proportion to the universe, it 1 s nevertheless felt that relative "1ikes" and "dislikes" can be meaningfully studied.

There is one important observation which is clearly evident in the overall evaluation of Table 13; namely, the average college-educated person did not view as much television as did the average person with less than thirteen years of schooling. If the "Tota1 Sample Distribution" column is taken as the "base," and then compared with the "Actual Viewing Distribution" column, one can readily see how this viewing pattern develops for both heads of households and housewives.

\section{B. Explanation of Data}

As in the case of the viewer's age and sex (Chapter v), a11 education data which follow were carefully weighted in terms of program ratings. Tables 15 and 16 illustrate the distribution of viewers by education to program types telecast during the daytime and during the evening .

A word of explanation should also be made regarding ARB's classification of "head of household" and "housewife." The term "head of household" refers to that person within the diary-keeping home who was primarily responsible for the upkeep of the household; therefore, this classification was not limited to the male sex. If a woman's husband was deceased, for instance, leaving her as the "head" of that household, then she not only would have been included as part of the "head of household" data, but also as part of the "housewife" data. It was possible, then, for the same person to be included in both categorles, provided that the head of household was a woman. 
TABLE 15

DISTRIBUTION OF VIEWERS BY EDUCATION TO PROGRAM TYPES

TELECAST DURING THE DAYTDME

(by percent of persons within each education category tuned to type) ${ }^{a}$

\begin{tabular}{|c|c|c|c|c|c|c|}
\hline \multirow{2}{*}{$\begin{array}{l}\text { Program Type } \\
\begin{array}{l}\text { Average Audience } \\
\text { to All Types }\end{array}\end{array}$} & \multicolumn{3}{|c|}{$\frac{\text { Head of Household }}{\text { Under } 99-12 \quad 13 \text { plus }}$} & \multicolumn{3}{|c|}{ Housewife $e^{b}$} \\
\hline & 24 & 49 & 27 & 13 & 63 & 24 \\
\hline $\begin{array}{l}\text { Talent Variety } \\
\text { General Variety }\end{array}$ & $\begin{array}{l}28 \\
31\end{array}$ & $\begin{array}{l}56 \\
52\end{array}$ & $\begin{array}{l}16 \\
17\end{array}$ & $\begin{array}{l}18 \\
14\end{array}$ & $\begin{array}{l}68 \\
62\end{array}$ & $\begin{array}{l}14 \\
24\end{array}$ \\
\hline $\begin{array}{l}\text { General Drama ( } \frac{1}{2} \text { hour) } \\
\text { Situation Comedy } \\
\text { Westerns } \\
\text { Women's Serials }\end{array}$ & $\begin{array}{l}29 \\
26 \\
29 \\
29\end{array}$ & $\begin{array}{l}54 \\
57 \\
47 \\
54\end{array}$ & $\begin{array}{l}17 \\
17 \\
24 \\
17\end{array}$ & $\begin{array}{l}13 \\
13 \\
14 \\
14\end{array}$ & $\begin{array}{l}68 \\
69 \\
68 \\
68\end{array}$ & $\begin{array}{l}19 \\
18 \\
18 \\
18\end{array}$ \\
\hline $\begin{array}{l}\text { Audience Participation } \\
\text { Quiz Panel }\end{array}$ & $\begin{array}{l}29 \\
18\end{array}$ & $\begin{array}{l}56 \\
48\end{array}$ & $\begin{array}{l}15 \\
34\end{array}$ & $\begin{array}{l}15 \\
12\end{array}$ & $\begin{array}{l}67 \\
54\end{array}$ & $\begin{array}{l}18 \\
34\end{array}$ \\
\hline Public Affairs & 20 & 46 & 34 & 11 & 59 & 30 \\
\hline Sports Events & 10 & 47 & 43 & 7 & 60 & 33 \\
\hline $\begin{array}{l}\text { Children's Drama } \\
\text { Children's Varlety } \\
\text { Cartoon Comedy }\end{array}$ & $\begin{array}{l}23 \\
26 \\
44\end{array}$ & $\begin{array}{l}58 \\
43 \\
14\end{array}$ & $\begin{array}{l}19 \\
31 \\
42\end{array}$ & $\begin{array}{l}20 \\
15 \\
22\end{array}$ & $\begin{array}{l}60 \\
58 \\
62\end{array}$ & $\begin{array}{l}20 \\
27 \\
16\end{array}$ \\
\hline Teenage Dance & 30 & 51 & 19 & 12 & 71 & 17 \\
\hline Miscellaneous & 28 & 40 & 32 & 13 & 60 & 27 \\
\hline
\end{tabular}

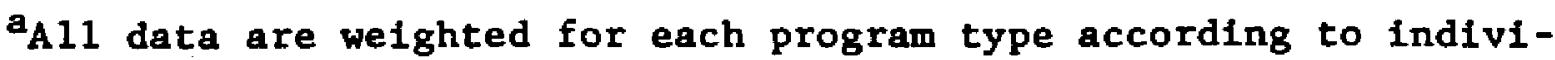
dual ratings received by the programs included within each type.

bIn terms of number of school years completed. 
TABLE 16

DISTRIBUTION OF VIEWERS BY EDUCATION TO PROGRAM TYPES TELLCAST DURING THE NIGHTTIME

(by percent of persons within each education category tuned to type) ${ }^{a}$

\begin{tabular}{|c|c|c|c|c|c|c|}
\hline \multirow{2}{*}{$\begin{array}{l}\text { Program Type } \\
= \\
\text { Average Audience } \\
\text { to All Types }\end{array}$} & \multicolumn{3}{|c|}{$\frac{\text { Head of Household }}{\text { Under } 99-1213 \text { plus }}$} & \multicolumn{3}{|c|}{$\frac{\text { Housewtfe }}{\text { Under } 99-12 \quad 13 \text { plus }}$} \\
\hline & 17 & 53 & 30 & 11 & 64 & 25 \\
\hline Concert Music & 15 & 50 & 35 & 10 & 58 & 32 \\
\hline $\begin{array}{l}\text { Music Variety } \\
\text { Comedy Variety } \\
\text { General Variety }\end{array}$ & $\begin{array}{l}15 \\
13 \\
14\end{array}$ & $\begin{array}{l}54 \\
51 \\
52\end{array}$ & $\begin{array}{l}31 \\
36 \\
34\end{array}$ & $\begin{array}{r}12 \\
9 \\
11\end{array}$ & $\begin{array}{l}61 \\
63 \\
59\end{array}$ & $\begin{array}{l}27 \\
28 \\
30\end{array}$ \\
\hline $\begin{array}{l}\text { General Drama ( } \frac{1}{2} \text { hour) } \\
\text { General Drama }(1 \text { hour) } \\
\text { Situation Comedy } \\
\text { Suspense Drama } \\
\text { Action Adventure } \\
\text { Crime Detective } \\
\text { Westerns } \\
\text { Feature Films }\end{array}$ & $\begin{array}{l}16 \\
15 \\
18 \\
15 \\
17 \\
16 \\
20 \\
14\end{array}$ & $\begin{array}{l}53 \\
52 \\
54 \\
50 \\
55 \\
54 \\
56 \\
55\end{array}$ & $\begin{array}{l}31 \\
33 \\
28 \\
35 \\
28 \\
30 \\
24 \\
31\end{array}$ & $\begin{array}{r}11 \\
9 \\
12 \\
10 \\
10 \\
10 \\
15 \\
10\end{array}$ & $\begin{array}{l}60 \\
65 \\
65 \\
67 \\
68 \\
66 \\
66 \\
66\end{array}$ & $\begin{array}{l}29 \\
26 \\
23 \\
23 \\
22 \\
24 \\
19 \\
24\end{array}$ \\
\hline $\begin{array}{l}\text { Audience Participation } \\
\text { Game Pane1 }\end{array}$ & $\begin{array}{l}19 \\
16\end{array}$ & $\begin{array}{l}56 \\
52\end{array}$ & $\begin{array}{l}25 \\
32\end{array}$ & $\begin{array}{l}13 \\
12\end{array}$ & $\begin{array}{l}64 \\
61\end{array}$ & $\begin{array}{l}23 \\
27\end{array}$ \\
\hline $\begin{array}{l}\text { News } \\
\text { Public Affairs } \\
\text { Documentary }\end{array}$ & $\begin{array}{l}19 \\
13 \\
13\end{array}$ & $\begin{array}{l}49 \\
44 \\
54\end{array}$ & $\begin{array}{l}32 \\
43 \\
33\end{array}$ & $\begin{array}{r}14 \\
9 \\
11\end{array}$ & $\begin{array}{l}60 \\
56 \\
62\end{array}$ & $\begin{array}{l}26 \\
35 \\
27\end{array}$ \\
\hline Sports Events & 23 & 52 & 25 & 14 & 62 & 24 \\
\hline $\begin{array}{l}\text { Children's Drama } \\
\text { Children's Variety } \\
\text { Cartoon Comedy }\end{array}$ & $\begin{array}{l}22 \\
20 \\
14\end{array}$ & $\begin{array}{l}52 \\
48 \\
56\end{array}$ & $\begin{array}{l}26 \\
32 \\
30\end{array}$ & $\begin{array}{r}14 \\
14 \\
9\end{array}$ & $\begin{array}{l}65 \\
57 \\
67\end{array}$ & $\begin{array}{l}21 \\
29 \\
24\end{array}$ \\
\hline Miscellaneous & 9 & 48 & 43 & 7 & 56 & 37 \\
\hline
\end{tabular}

${ }^{a_{A} 11}$ data are welghted for each program type according to individual ratings recelved by the programs within each type.

${ }^{b}$ In terms of number of school years completed. 
Once again, the data Included in Tables 15 and 16 are in terms of actual viewing. If a head of household or housewife in a given diary was not included in the viewing to a specific program, then that diary was not credited to elther of these categorles. Therefore, it should be stressed that in the case of children's programs, in particular, where there was oftentimes minimal viewing, the number of sample cases was likewise small, thus creating a greater chance for statistical error. However, in most cases, the three-month sample for other program types was more than sufficlent for reporting reliable indications. It should also be pointed out that, generally speaking, there was a small proportion of head-of-household viewers to daytime programs (except Saturday and Sunday).

\section{Viewing Patterns of Various Education Groups}

This section is devoted to a discussion of the educational background of heads of households and housewives viewing specific program types as defined in Chapter III. Since the educational background sometimes differs depending upon the time of day a program was telecast, then both daytime and nighttime viewing characteristics w111 be presented. Each education category is discussed individually.

Head of Household (Daytime Viewing)

Under nine years of school completed. During the average daytime program, $24 \%$ of the head-of-household audience consisted of people with less than nine years of formal education. In looking at the specific program types, however, striking differences from this "base" figure 
were noted throughout. During the daytime, for instance, $44 \%$ of the head-of-household audience in this education category viewed Cartoon Comedy, while only $10 \%$ viewed Sports Events. These were the two extremes in viewing noted during the sign-on to 6:00 PM period.

Besides Cartoon Comedy, other program types which were aboveaverage in attraction (considering that $24 \%$ is "average") were General Variety (31\%); Teenage Dance (30\%); General Drama -- half-hour, Westerns, Women's Serials, Audience Participation (each 29\%); Talent Variety (28\%); Situation Comedy and Children's Variety (each 26\%).

In addition to Sports Events, other program types which were below-average In attraction were Children's Drama (23\%); Public Affairs (20\%); and Quiz Panel (18\%).

Nine to twelve years of school completed. Slightly less than half (49\%) of the daytime head-of-household audience was made up of people with from nine to twelve years of schooling.

Strangely enough, the program type which was found most attractive by this education group was Children's Drama (58\%). It should be kept In mind, once again, that the sample size of adult viewers to children's programs was somewhat less than for the average "adult" program. Statistically speaking, then, the small sample may in part account for this result.

other types found particularly attractive by heads of households falling within this education bracket were S1tuation Comedy (57\%); Talent Variety, Audience Participation (each 56\%); General Drama -- halfhour, Women's Serials (each 54\%); General Variety (52\%); and Teenage 
Dance (51\%). It is interesting to note that Sports Events are absent from this 1fsting.

Those program types found less attractive than average by heads of households were Quiz Panel (48\%); Westerns, Sports Events (each 47\%); Public Affairs (46\%); Children's Variety (43\%); and Cartoon Comedy (14\%).

Thirteen and more years of school completed. Of the total number of heads of households viewling the average daytime television program, 27\% had completed one or more years of college training. The most attractlve program type, Sports Events, had $43 \%$ college-trained people in Its head-of-household audience. Cartoon Comedy was a close second (42\%), but again, this may have been the reflection of a small sample size.

The three remaining above-average types found attractive by college-trained heads of households were Qulz Panel, Public Affalrs (each $34 \%$ ); and Children's Variety (31\%).

Finally, the types found less-than-average in attractiveness were Westerns (24\%); Teenage Dance, Chlldren's Drama (19\%); General Varfety, General Drama -- half-hour, Situation Comedy, Women's Serlals (each 17\%); Talent Variety (16\%); and Audience Particfpation (15\%).

Housewife (Daytime V1ewing)

Under nine years of school completed. It is interesting to note that while $24 \%$ of the average head-of-household audience to daytime programs was composed of persons with under nine years of education, only 13\% of the average housewife audience had the same educational back- 
ground. Except for a couple of Instances, the viewing pattern of housewives in this category seemed to be somewhat more stable than in the head-of-household "under nine years" category. To an extent, this was true of all housewives, regardless of amount of formal schooling. This may possibly indicate that housewives were not particularly selective, at least compared with heads of households, during daytime television. Of the fourteen program types included in the daytime portion of this study, eight of them received an above-average housewife audience (considering $13 \%$ to be "average"), In terms of women with less than nine years of formal education. In decreasing order, these types were Cartoon Comedy (22\%); Children's Drama (20\%); Talent Variety (18\%); Audience Participation, Children's Variety (each 15\%); General Variety, Westerns and Women's Serfals (each 14\%).

Two program types (General Drama -- half-hour, and Situation Comedy) appeared to have an average appeal for this education group -$13 \%$ was attracted to each.

The remaining four types apparently were not particular favorites with this group of housewtves -- Quiz Panel, Teenage Dance (each 12\%); Public Affairs (11\%); and Sports Events (7\%).

Nine to twelve years of gchool completed. By far, the majority of housewives in the daytime audience (63\%) were women with from nine to twelve years of formal schooling to their credit. Again, as in the case of the housewife with less education than this group, few significant differences in viewing patterns existed during daytime television. Teenage Dance was the outstanding attraction for this education 
segment -- 71\% of the housewife audience was made up of women who had attended or graduated from high school. Other above-average attractions were Situation Comedy (697); Talent Varlety, General Drama -- half-hour, Westerns, Women's Serials (each 68\%); and Audience Participation (67\%). 0 Quiz Panel attracted this group the least (54\%), while General Variety (62\%), Cartoon Comedy (62\%), Sports Events (60\%), Ch1ldren's Drama (60\%) and Children's Variety (58\%) showed a slightly less-thanaverage attraction for this group.

Thirteen and more years of school completed. College-trained housewives were attracted particularly to Qufz Panel programs, and strangely enough, Sports Events. ${ }^{3}$ Thirty-four percent of the daytime housewife audience to Quiz Panel and $33 \%$ of the daytime housewife audience to Sports Events consisted of women with thirteen or more years of education. This represents a college-educated audience which was considerably greater in size than that of the average daytime program (24\%). Two other program types which were found to be more attractive than average were Public Affairs (30\%) and Chlldren's Variety (27\%). To digress for a moment, it is conceivable in the case of ch11dren's programs, for Instance, that many heads of households and housewives, regardless of education, were more or less "forced into watching," due to pressures imposed by their youngsters. Therefore, the statement

3 The high incidence of housewife viewers to Sports Events may have come about as the result of males in the household tuning in the program, or, like chlldren's programs, it may have been due to a gmall sample size for the type. Since the results reported in this section are in terms of actual viewing, if the number of viewers to any given program type was small, then greater statistical error was possible. 
that a head of household or housewife is "attracted" to children's programing should be prefaced with this thought in mind.

Some viewing, then, might be said to be dependent upon environmental circumstances, such as when the child is given authority to chpose the program. By the same token, the same principle can be applied to other program types, as well as to other members of the family. Program types that were found less-than-average in attractiveness by this education group were Children's Drama (20\%); General Drama -half-hour (19\%); Situation Comedy, Westerns, Women's Serials, Audience Particlpation (each 18\%); Teenage Dance (17\%); Cartoon Comedy (16\%); and Talent Varlety (14\%).

One program type (General Variety) was the only so-called "average" type Insofar as this education category was concerned (24\% of the housewife audience was composed of women with college training).

Head of Household (Nighttime viewing)

Under nine years of school completed. Unlike daytime Sports Events which did not attract many heads of households with less than nine years of education, nighttime Sports Events did attract that same element of the population. In fact, this program type was found to be the most attractive of all to this group of heads of households. Twentythree percent of the head-of-household audience to Sports Events consisted of people with only a grammar school background. The difference in daytime versus nighttime viewing may have been due, in part, to the types of sporting events offered during the two times of the day. As was stated in Chapter $v$, nighttime sports were limited to boxing and bowling, 
whereas daytime sports included football, basketball and golf. This again suggests that different sports attract different audiences. other program types viewed most extensively by this education group were Chlldren's Drama (22\%); Westerns, Chlldren's Variety (each 20\%); Audience Participation, News (each 19\%); and SItuation Comedy (18\%)

Action Adventure followed these types with an average nighttime head-of-household audience of $17 \%$ people with under nine years of formal education. Action Adventure represented the typical nighttime program Insofar as audience composition was concerned relative to the education category.

On the other side of the coin, these program types were noted by the writer as being somewhat less-than-average in attractiveness: General Drama -- half-hour, Crime Detective, Game Panel (each 16\%); Concert Music, Music Varfety, General Drama -- one hour, Suspense Drama (each 15\%); General Variety, Feature Films, Cartoon Comedy (each 14\%); Comedy Varlety, Public Affatrs and Documentary (each 13\%).

Nine to twelve years of school completed. During the average nighttime program, $53 \%$ of the head-of-household audience was made up of people who had either attended or graduated from high school.

It is interesting to note that many program types fell very close to this $53 \%$ average.

Fifty-six percent of the head-of-household audience to Westerns, Audience Participation and Cartoon Comedy consisted of people with from nine to twelve years of schooling. These, then, were the most popular 
program types for this education segment during the three-month period under study.

The remaining types, in order of greatest to least attractiveness were Feature Films, Action Adventure (each 55\%); Music Variety, Situation Comedy, Crime Detective, Documentary (each 54\%); General Drama -- halfhour (53\%); General Variety, General Drama -- one hour, Game Pane1, Sports Events, Children's Drama (each 52\%); Comedy Variety (51\%); Concert Music, Suspense Drama (each 50\%); News (49\%); Children's Variety (48\%); and Public Affairs (44\%).

Thirteen and more years of school completed. The average night time head-of-household audience consisted of $30 \%$ people who had completed thirteen or more years of schooling. Two program types (Crime Detective and Cartoon Comedy) might be considered "average" in that each of them was credited with $30 \%$ people from this education group.

The one outstanding program type that was found particularly attractive was Public Affairs. Forty-three percent of the Public Affairs head-of-household audience was made up of college educated people.

Other types found above-average In attractiveness were Comedy Variety (36\%); Concert Music, Suspense Drama (each 35\%); General Variety (34\%); General Drama -- one hour, Documentary (each 33\%); Game Panel, News, Children's Varlety (each 32\%); Music Varlety, General Drama -half-hour and Feature Films (each 31\%).

Program types found by this group to be less-attractive-thanaverage were Action Adventure, Situation Comedy (each 28\%), Children's 
Drama (26\%); Sports Events, Audience Participation (each 25\%); and Westerns (24\%).

Housewife (N1ghttime Viewing)

Under nine years of schoo1 completed. Considering the housewife audience as an exclusive group, the typical nighttime program contained on 1y $11 \%$ women with less than nine years of formal education. In this respect, three types could probably be considered typical in that the housewife segment contained exactly $11 \%$ from this education group. These were General Variety, General Drama -- half-hour, and Documentary. of more appeal, however, were these types: Westerns (15\%); News, Sports Events, Children's Drama and Children's Varlety (each 14\%); Audience Particlpation (13\%); Music Variety, Situation Comedy and Game Panel (each 12\%).

A11 other program types consisted of elther 9 or 10\% grade-schooleducated housewives in their total housewife audiences: Concert Music, Suspense Drama, Action Adventure, Crime Detective, Feature Films (each 10\%); Comedy Varlety, General Drama -- one hour, Public Affairs and Cartoon Comedy (each 9\%).

Nine to twelve years of school completed. The nighttime housewife audience was, overall, very similar to that of the daytime, insofar as educational background is concerned. For instance, a reference to Tables 15 and 16 shows that $64 \%$ of the nighttime housewife audience consisted of women with from nine to twelve years of education, as opposed to $63 \%$ for the daytime audience. Striking similarities are also appar- 
ent relative to the other two education categorles established for this study.

Audience Particlpation programs contained a "typical" housewife audience in that they consisted of $64 \%$ women with from nine to twelve years of schooling.

Slightly above-average program types were Action Adventure (68\%); Suspense Drama, Cartoon Comedy (each 67\%); Crime Detective, Westerns, Feature Films (each 66\%); General Drama -- one hour, Situation Comedy and Children's Drama (each 65\%).

The remalning types, of course, were found to be less-thanaverage in attractiveness: Comedy Variety (63\%); Documentary, Sports Events (each 62\%); Music Variety, Game Pane1 (each 61\%); General Drama -- half-hour, News (each 60\%); General Varlety (59\%); Concert Music (58\%); Children's Variety (57\%); and Public Affairs (56\%).

Thirteen and more years of school completed. College-educated housewives made up $25 \%$ of the average housewife audience to nighttime programs .

The most popular type for this group was Public Affairs; $35 \%$ of all housewives viewing this program type were women with thirteen or more years of education. As might be expected, Concert Music (32\%) followed closely. Next, in order of importance, were General Variety (30\%); General Drama -- half-hour, Children's Variety (29\%); Comedy Variety (28\%); Music Variety, Game Pane1, Documentary (27\%); General Drama -one hour, and News (26\%).

Falling below the average $25 \%$-audience were Crime Detective, 
Feature F1lms, Sports Events, Cartoon Comedy (each 24\%); Situation Comedy, Suspense Drama, Audience Participation (each 23\%); Action Adventure (22\%); Children's Drama (21\%); and Westerns (19\%).

\section{Discussion of Individual Programs}

In Chapter $\mathrm{V}$, several programs were discussed individually, due to theix either being somewhat different in nature than most of the programs within their classified group, or they were not readily classifiable. It is felt that these same programs should again be discussed individually, this time in terms of education of viewers to those programs.

"Video Village, Jr." Since this program was aimed specifically at youngsters, the sample size used to compute head-of-household and housewife data was relatively sma11. To break out this small sample would be misleading; therefore, no information is provided.

"Mr. Wizard." Again, for the same reason as "Video Village, Jr.," no information is provided for this program.

"Bob Newhart." To say that this program attracted the "sophisticated" viewer probably is an understatement. Forty-seven percent of the head-of-household audience, for instance, was composed of people with at least some college training.

The housewife audience showed much the same pattern. According to Table 17, 33\% of the housewives viewing "Bob Newhart" had thirteen or more years of formal education.

The high-school-educated viewer was attracted somewhat less to 
this program than to the average nighttime program; however, the viewer with less than nine years of education watched this program far less than he watched the average nighttime program.

TABLE 17

DISTRIBUTION OF VIEWERS BY EDUCATION TO SPECIFIC PROGRAMS

(by percent of persons within each education category tuned to program)

\begin{tabular}{|c|c|c|c|c|c|c|}
\hline \multirow[b]{2}{*}{ Program Name } & \multicolumn{3}{|c|}{ Head of Household ${ }^{a}$} & \multicolumn{3}{|c|}{ Housewife $e^{a}$} \\
\hline & Under & $9-1$ & 3 plus & Under & $9-12$ & 3 plus \\
\hline $\begin{array}{l}\text { Bob Newhart } \\
\text { Ernie Kovacs } \\
\text { Jack Benny } \\
\text { Red Skelton } \\
\text { Steve Allen } \\
\text { Jack Paar } \\
\text { Brinkley's Journal } \\
\text { Today }\end{array}$ & $\begin{array}{r}8 \\
9 \\
14 \\
18 \\
11 \\
8 \\
10 \\
19\end{array}$ & $\begin{array}{l}45 \\
47 \\
48 \\
56 \\
51 \\
49 \\
43 \\
47\end{array}$ & $\begin{array}{l}47 \\
44 \\
38 \\
26 \\
38 \\
43 \\
47 \\
34\end{array}$ & $\begin{array}{r}5 \\
1 \\
11 \\
14 \\
7 \\
4 \\
7 \\
13\end{array}$ & $\begin{array}{l}62 \\
65 \\
57 \\
65 \\
67 \\
63 \\
55 \\
55\end{array}$ & $\begin{array}{l}33 \\
34 \\
32 \\
21 \\
26 \\
33 \\
38 \\
32\end{array}$ \\
\hline
\end{tabular}

${ }^{\text {an }}$ terms of number of school years completed.

"Ernie Rovacs." This program, like "Bob Newhart," also tended to attract people with higher educations. Forty-four percent of the head-of-household audience, and $34 \%$ of the housewife audience was composed of people with some college training. Again, this is somewhat higher than the same education segment generally contributed to the average nighttime program.

An increase over the average audience was also noted in the case of housewives with high school training. Sixty-five percent of the housewife audience tuned to "Ernfe Kovacs" was made up of women with from nine to twelve years of education.

Only $1 \%$, on the other hand, had less than nine years of education. 
"Jack Benny." Heads of households and housewives with an education background of less than nine years viewed "Jack Benny" considerably more than they viewed either "Bob Newhart" or "Ernie Kovacs." This undoubtedly 1s due in part to the.type of humor presented by Benny -- less sophisticated and more comprehendible.

According to Table 17, 14\% of the head-of-household audience, and 11\% of the housewife audience consisted of people with under nine years of education.

This, however, does not mean that college-educated people did not vlew Benny. On the contrary, the head-of-household audience was composed of $38 \%$ people with at least some college training. This is $8 \%$ higher than the same education group contributed to the average nighttime program.

Along these same lines, $32 \%$ of the housewives in the "Jack Benny" audience were women with college training. This figure, too, is higher than the average nighttime program, by $7 \%$.

The high-school-educated segment of the audience contributed $48 \%$ to the head-of-household data, and $57 \%$ to the housewife data -- somewhat less than this education group contributed to the average nighttime program.

"Red Skelton." As might be expected, the "Red Skelton" audience contained less people with college training than any of the other four programs within this type (Comedy Variety).

The head-of-household audience contained $18 \%$ people with less than nine years of education, $56 \%$ with from nine to twelve years, and 
26\% with thirteen or more years. Housewives tended to follow the same general trend of vlewing. Fourteen percent of the housewife viewers were women with under nine years of schooling, $65 \%$ with from nine to twelve years, and $21 \%$ with thirteen or more years.

"Steve Allen." The more educated heads of households viewed "Steve Allen" in a manner simflar to "Jack Benny." Those with college training consisted of $38 \%$ of the audience to both programs.

People with some high-school training amounted to $51 \%$ of the total head-of-household audience to Allen, leaving the remaining $11 \%$ to be made up of people with less than nine years of formal schooling.

Insofar as the housewife segment of the Allen audience was concerned, $26 \%$ consisted of women with college training, $67 \%$ of women with high-school trainfing, and only $7 \%$ with less than nine years of education.

"Jack Paar." The people who were attracted to the "Jack Paar" programs generally were those with a better educational background.

For Instance, $43 \%$ of the heads of households viewing Paar had thirteen or more years of formal training. This is $13 \%$ higher than college-trained people contributed to the average nighttime program.

The housewives viewing this program also were better educated than the normal housewife audience to the typical nighttime program. Thirtythree percent of this audlence consisted of women with some college background.

The remainder of the head-of-household audience was made up of $8 \%$ people with under nine years of education, and $49 \%$ with from nine to twelve years. 
The remainder of the housewife audience consisted of $4 \%$ women with under nine years of education, and $63 \%$ with from nine to twelve years.

"Brinkley's Journal." Since "Brinkley's Journal" closely approximated the Public Affalrs program type category, one would probably expect the high Incidence of college-tralned people that existed in its audience.

People with over thirteen years of education consisted of $47 \%$ of the total head-of-household audience. When this is compared with the $30 \%$ average which was found for the typical nighttime program, one can readily see that the difference is a signiflcant one.

Likewise, the housewife audience was made up of $38 \%$ collegetrained women. Th1s, too, is considerably higher than the $25 \%$ average for this education segment in relation to the average nighttime program. Only $10 \%$ of the Brinkley head-of-household audience consisted of people with under nine years of formal schooling, while $43 \%$ consisted of people with from nine to twelve years of schooling.

The remainder of the Brinkley housewife audience was made up of $7 \%$ women with less than nine years of education, and $55 \%$ with from nine to twelve years.

"Today." This program was probably less sophisticated in nature of presentation than was "Brinkley's Journal." Therefore, it tended to attract a less sophisticated audience.

Nineteen percent of the heads of households in the "Today" audience were people with an educational background of less than nine years. 
Forty-seven percent of the head-of-household segment had from nine to twelve years of schooling, while $34 \%$ had some college training. Housewives, too, viewed "Today" in a somewhat similar pattern. Thirteen percent of this audience had less than nine years of education, $55 \%$ had from nine to twelve years, and $32 \%$ had thirteen or more years.

\section{E. Genera1 Observations}

Further analysis of Tables 15 and 16 reveals the following:

(1) More soph1sticated music programs (i.e., Concert Music) tended to attract the more sophisticated audience, at least in terms of general educational background.

(2) Variety programs telecast in the evening tended to attract the more educated audience; however, the reverse was true of daytime programs in the same category. The latter may have been due, in part, to the limited number of daytime varlety programs avallable for study here. Only one daytime program was represented in Talent Variety, and one in General Variety. Therefore, the results might be somewhat different if a greater number of daytime varlety programs were available for examination.

(3) Nighttime dramatic programs taken as a whole varied little within the various program types represented, in terms of education of viewers. Half-hour drama attracted a more educated housewife audience than did the average dramatic program. Westerns, on the other hand, attracted particularly those heads of households and housewives with less education (under 
thirteen years). Suspense Drama, too, was somewhat "out of Ine" with the rest of the nighttime dramas in that it tended to have a high percentage (35\%) of college-trained heads of households in its audience.

(4) Daytime dramatic programs were generally found more attractive to people with grammar and high-school educations than they were to college-trained people. This possibly may have been related to "availability." It is conceivable that the majority of college-tralned people were at work (white collar jobs), and thus not available for viewing.

(5) Significant dissimilarities existed in Audience Participation type programs. For Instance, the less sophisticated daytime programs (i.e., "Concentration," "Make a Face," etc.) drew a less sophisticated audience. By the same token, a program of the nature of "College Bowl" tended to attract people with better educational backgrounds.

(6) Programs which might be classified generally as "straight talks" (1.e., News and Public Affairs) were watched to a greater degree by the more educated person. However, News was found significantly more attractive to the high-school and grade-school-educated person than was Public Affalrs.

(7) Daytime Sports Events were viewed considerably more by the college-trained person than was the average daytime program. This was true for both heads of households and housewives.

(8) Nighttime Sports Events, however, were found more attractive to people in the two lower education categories than in the 
upper category. Again, as mentioned previously, this probably is due to the types of Sports Events represented in each portion of the broadcast day.

(9) Children's programs varied considerably in audience composition. Some of the fluctuation may have been due to a sometimes less-than-adequate sample of heads of households and housewives in the individual program audiences. However, by putting several programs together, as was done in this study, some of the instability has been erased. Nevertheless, the writer does not wish to make any conclusions regarding the educational background of adult viewers to children's programs. (10)Heads of households and housewives with a grade-school or highschool education were attracted far more to Teenage Dance than was the college-educated person.

The final results of this chapter strengthen the point made in one of the early paragraphs regarding the importance of knowing as much as possible about the educational background of television viewers. Programs and program types do vary considerably in this respect, and a wise television advertiser will learn as much as he can about a given program's audience before spending a lot of money haphazardly. 
THE RELATIONSHIP OF PROGRAM-TYPE APPEAL TO THE FAMILY INCOME OF THE VIEHER

Some of the most interesting and most revealing data which the television researcher can provide pertains to the family income-level of viewers to specific programs and program types.

To cite an example of the importance of income, Cadillac would most certainly be interested in an audience consisting mainly of famiIles in the upper income brackets. Chevrolet, on the other hand, would probably be more interested in the middle and low-income households. However, Chevrolet would undoubtedly also have a secondary interest in the hIgher Income family, and perhaps would use the approach of selling It a "second" car.

Like education, then, family income should be studied carefully by the prospective program sponsor.

\section{A. Family Income of the Average Television Viewer}

What is the family income of the average television viewer in this country? To answer this question, all data pertaining to family Income were averaged for the three-month perlod of this study and, at the same time, weighted according to the ratings received by the individual programs.

In order to make this "actual viewing" data as meaningful as possible, they are compared in Table 18 with (1) Bureau of the Census data 
relative to family Income in the United States, and (2) total sample distribution of ARB's diaries for the months of October, November and December, 1961. All data are in terms of total income before tax deductions.

TABLE 18

BUREAU OF CENSUS AND ARB DATA COMPARISONS RELATIVE TO FAMILY INCOME

(by percent of families falling within each income category)

\begin{tabular}{|c|c|c|}
\hline & \multicolumn{2}{|c|}{ Family Income } \\
\hline Source & Under $\$ 7000$ & $\$ 7000$ plus \\
\hline $\begin{array}{l}\text { Bureau of Census } 1 \\
\text { ARB TV National (sample distribution) } \\
\text { ARB TV National (actual TV viewing) }\end{array}$ & $\begin{array}{l}64.8 \\
67.0 \\
64.5\end{array}$ & $\begin{array}{l}35.2 \\
33.0 \\
35.5\end{array}$ \\
\hline
\end{tabular}

According to the Bureau of the Census, $64.8 \%$ of the total U.S. families claimed total incomes of less than $\$ 7000$ per year, while the remaining $35.2 \%$ claimed incomes of $\$ 7000$ or more. This compares quite favorably with the ARB total sample distribution which found $67.0 \%$ of the diarles coming from homes claiming an annual income of less than $\$ 7000$, and the remaining $33.0 \%$ from homes claiming $\$ 7000$ or more.

It is interesting to compare the total ARB sample distribution with the actual TV viewing distribution by income-1evel. Such a comparison shows that the average family which claimed an annual income of

1 U.S. Bureau of the Census, U.S. Census of Population: 1960. General Soctal and Economic Characteristics, United States Sumary. Final Report PC(1)-IC (U.S. Government Printing office, Washington, D.C., 1962), p. 1-226. 
$\$ 7000$ or more tended to view television slightly more than the famlly with less income. This finding is probably contrary to most industry people's thinking on the subject.

\section{B. Explanation of Data}

During each of the survey perfods covered by this study, the respondents were asked to answer the following question which was included on the tnside back page of the diary:

Which of the following best describes your total family income?

$\begin{array}{lll}\begin{array}{c}\text { Weekly } \\ \text { Under } \$ 49\end{array} & \begin{array}{c}\text { Monthly } \\ \text { Under } \$ 209\end{array} & \begin{array}{c}\text { Yearly } \\ \text { Under } \$ 2,500\end{array} \\ \$ 49 \text { to } \$ 76 & \$ 209 \text { to } \$ 333 & \$ 2,500 \text { to } \$ 3,999 \\ \$ 77 \text { to } \$ 134 & \$ 334 \text { to } \$ 583 & \$ 4,000 \text { to } \$ 6,999 \\ \$ 135 \text { to } \$ 192 & \$ 584 \text { to } \$ 833 & \$ 7,000 \text { to } \$ 9,999 \\ \$ 193 \text { or more } & \$ 834 \text { or more } & \$ 10,000 \text { or more }\end{array}$

Since ARB felt that people may tend to exaggerate their income slightly, the decision for final tabulation was made to report only two classifications -. "under $\$ 7000 "$ and "\$7000 plus."

It should also be kept in mind that ARB's results are in terms only of those people who answered the above question. If the diarykeeper falled to answer this question, which sometimes happened, then the "income" results for a gtven program were based only on those diaries which contained answers to the income question.

Finally, the results contalned in the following section of this chapter pertain only to actual viewing, and all results for the viewers are in terms of the total income of the families from which those viewers came. 


\section{Viewing Patterns of Various Family Income Groups}

Slight differences were noted between the family income of daytime versus nighttime viewers; however, these differences do not appear to be too significant. For instance, according to Table $19,66 \%$ of the viewers to daytime television claimed family incomes of less than $\$ 7000$ per year. Table 20 , at the same time, shows $64 \%$ of the evening viewers claiming incomes of less than $\$ 7000$. It would seem, then, from this analysis, that there were no substantial overall differences in the incomes of families viewing in the daytime as opposed to those viewing at night. However, since there were sometimes wide variations within the same program types when telecast in the daytime as opposed to the evening, the discussion that follows will take into consideration both time spans.

Famfly Income Analysis of Daytime Viewers

Under $\$ 7000$. Assuming that $66 \%$ of the average daytime viewing families in this study had annual incomes of less than $\$ 7000$ (Table 19), one can use this percentage as the "base" for analyzing the Individual program types within this income group.

The two program types which were found most attractive to viewers coming from families with incomes of less than $\$ 7000$ were Talent Varlety and Women's Serfals. In both instances, $77 \%$ of the total viewers to these types were from the lower income-level homes. These two types appeared to have a significantly higher percentage of people from this income group than any other types in the entire study. 
TABIE 19

DISTRIBUTION OF VIEWERS BY FAMILY INCOKE TO PROGRAM TYPES TELBCAST DURING THE DAYTTME

(by percent of persons within each family income category tuned to type) ${ }^{a}$

\begin{tabular}{|c|c|c|}
\hline \multirow{2}{*}{ Program Type } & \multicolumn{2}{|c|}{ Family Income } \\
\hline & & \\
\hline $\begin{array}{l}\text { Average Audience } \\
\text { to A11 Types }\end{array}$ & 66 & 34 \\
\hline $\begin{array}{l}\text { Talent Variety } \\
\text { Genera1 Variety }\end{array}$ & $\begin{array}{l}77 \\
72\end{array}$ & $\begin{array}{l}23 \\
28\end{array}$ \\
\hline $\begin{array}{l}\text { General Drama ( } \frac{1}{2} \text { hour) } \\
\text { Situation Comedy } \\
\text { Westerns } \\
\text { Women's Serials }\end{array}$ & $\begin{array}{l}71 \\
68 \\
72 \\
77\end{array}$ & $\begin{array}{l}29 \\
32 \\
28 \\
23\end{array}$ \\
\hline $\begin{array}{l}\text { Audience Participation } \\
\text { Quiz Panel }\end{array}$ & $\begin{array}{l}69 \\
65\end{array}$ & $\begin{array}{l}31 \\
35\end{array}$ \\
\hline Public Affairs & 67 & 33 \\
\hline Sports Events & 55 & 45 \\
\hline $\begin{array}{l}\text { Children's Drama } \\
\text { Children's Variety } \\
\text { Cartoon Comedy }\end{array}$ & $\begin{array}{l}65 \\
63 \\
62\end{array}$ & $\begin{array}{l}35 \\
37 \\
38\end{array}$ \\
\hline Teenage Dance & 71 & 29 \\
\hline Miscellaneous & 64 & 36 \\
\hline
\end{tabular}

$a_{A 11}$ data are weighted for each program type according to individual rating 8 received by the programs included within each type. 
TABLE 20

DISTRIBUTION OF VIENERS BY FAMILY INCOME TO PROGRAM TYPES TELECAST DURING THE NIGHTTDME

(by percent of persons within each family income category tuned to type) ${ }^{a}$

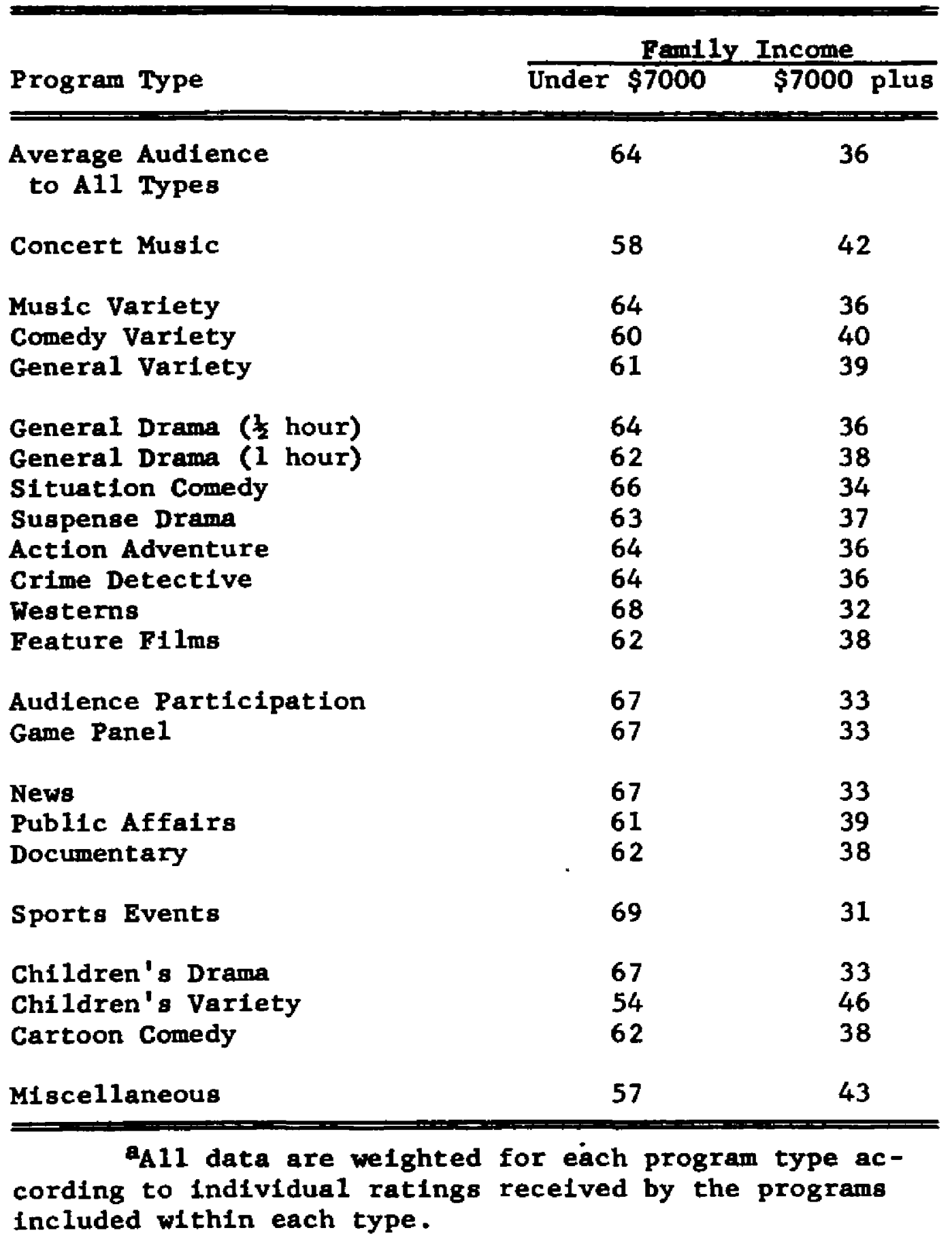


General Variety (727), Westerns (72\%), General Drama (71\%), and Teenage Dance (71\%) were the next most attractive types for this group. Next, in descending order, were Audience Participation (69\%), Situation Comedy (68\%) and Public Affairs (67\%).

The only program type which looks "out of line" here is Public Affairs, which one would normally think as attracting the higher income families. In fact, such is the case with nighttime Public Affalrs programs, as will be shown later in this chapter.

Program types which were viewed proportionately less-than-average ("average" being 66\%) were these: Quiz Panel, Children's Drama (each 65\%); Chlldren's Variety (63\%); Cartoon Comedy (62\%); and Sports Events (55\%).

$\$ 7000$ plus. Since only two income categories were reported by ARB, it would naturally follow that those program types found least attractive by one income group were found most attractive by the other group.

For instance, Sports Events (with $45 \%$ of the audience coming from families with Incomes of $\$ 7000$ or more) was found to be the most attractive program type for the "\$7000 plus" group. Like educational background (Chapter v), income level differed from daytime Sports Events to nighttime Sports Events. In the evening, the opposite viewIng pattern existed -- the lower Income familles were attracted more to Sports Events than were the upper income families. Again, this was probably due to the different types of sports telecast during the daytime and evening hours. 
Other above-average program types ("average" being 34\%) viewed by the "\$7000 plus" families were Cartoon Comedy (387); Children's Varlety (37\%); Quiz Panel and Children's Drama (each 35\%).

In descending order, those types which were found least attractive to this income group were Public Affatrs (33\%); Situation Comedy (32\%); Audience Participation (31\%); General Drama -- half-hour, Teenage Dance (each 29\%); General Varlety, Westerns (each 28\%); Talent Varfety and Women's Serials (each $23 \%$ ).

Family Income Analysis of Nighttime Viewers

Under $\$ 7000$. The viewing differences between program types within the nighttime section of this study were nowhere near so dramatic as in the daytime section. To be sure, there were some relatively significant differences, but overall the viewing patterns tended to be more stable in the evening.

The average audience during the nighttime programs was broken down in this manner: 64\% from families with an annual income of less than $\$ 7000$, and the remaining $36 \%$ from families with an annual income of $\$ 7000$ or more.

The program type which was found most attractive by the "under $\$ 7000 "$ famliles was Sports Events. In this case, $69 \%$ of the audience was composed of family members from households earning less than $\$ 7000$ per year.

Next most attractive types were Westerns (68\%); Audience Part1clpation, Game Panel, News, Children's Drama (each 67\%); and Situation Comedy (66\%). 
Four program types claimed 64\% ("average" audience) of the lower income families: Music Vartety, General Drama -- half-hour, Action Adventure and Crime Detective.

The rematning ten program types were found to be less-than-average In attractiveness for th1s income group: Suspense Drama (63\%); General Drama -- one hour, Feature Films, Documentary, Cartoon Comedy (each 62\%); General Varlety, Public Affalrs (each 61\%); Comedy Varlety (60\%); Concert Music (58\%); and Children's Variety (54\%).

$\$ 7000$ plus. Once again, the program types which were found least attractive to the lower income group were of course found most attractive to the higher income group. These were, in descending order, Children's Variety (46\%); Concert Music (42\%); Comedy Variety (40\%); General Varlety, Public Affalrs (each 39\%); General Drama -- one hour, Feature FIlms, Documentary, Cartoon Comedy (each 38\%); and Suspense Drama (37\%) .

Four program types claimed an "average" aud1ence from the "\$7000 pIus" families ("average" being 36\%): Music Vartety, General Drama -half-hour, Action Adventure and Crime Detective.

Program types claiming less than $36 \%$ of their average audiences were Situation Comedy (34\%); Audience Participation, Game Pane1, News, Ch11dren's Drama (each 33\%); Westerns (32\%); and Sports Events (31\%).

\section{Discusston of Individual Programs}

As in all preceding chapters, several programs will be discussed individually here since their formats, in most cases, do not lend them- 
selves to easy classification within speclfic program types. These programs are presented in Table 21.

\section{TABLE 21}

DISTRIBUTION OF VIEWERS BY FAMILY INCOME TO SPECIFIC PROGRAMS (by percent of persons within each family income category tuned to program)

\begin{tabular}{|c|c|c|}
\hline \multirow[b]{2}{*}{ Program Name } & \multicolumn{2}{|c|}{ Family Income } \\
\hline & Under $\$ 7000$ & $\$ 7000$ plus \\
\hline $\begin{array}{l}\text { Video Village, Jr. } \\
\text { Mr. Wizard } \\
\text { Bob Newhart } \\
\text { Ernie Kovacs } \\
\text { Jack Benny } \\
\text { Red Skelton } \\
\text { Steve Allen } \\
\text { Jack Paar } \\
\text { Brinkley's Journal } \\
\text { Today }\end{array}$ & $\begin{array}{l}66 \\
61 \\
52 \\
52 \\
63 \\
66 \\
58 \\
61 \\
53 \\
61\end{array}$ & $\begin{array}{l}34 \\
39 \\
48 \\
48 \\
37 \\
34 \\
42 \\
39 \\
47 \\
39\end{array}$ \\
\hline
\end{tabular}

"Video Village, Jx." When compared to all daytime programs, this program was "average" in respect to distribution of viewers accordIng to family income. Sixty-six percent of its viewing audience came from families claiming an annual income of less than $\$ 7000$, whereas $34 \%$ came from familiea claiming $\$ 7000$ or more.

"Mr. Wizard." When considering the average daytime viewing patterns, this program was viewed more heavily by higher income families (61\%) than by families earning less than $\$ 7000$ (39\%).

"Bob Newhart," "Ernie Kovacs," "Jack Benny," "Red Skelton," and "Steve Allen." As In the case of educational background, where "Bob Newhart" and "Emie Kovacs" attracted the "h1gh-brow" audience, both pro- 
grams also attracted members of higher income-level families. Fortyeight percent of the Newhart and Kovacs audiences were people from the "\$7000 plus" category. Considering that the average nighttime program was composed of only $36 \%$ people from this income segment, then this $12 \%$ difference is a relatively significant one.

The "Steve Allen" program was next most attractive to the higher income famfly (42\%), while the "Jack Benny" program was next (37\%), and "Red Ske1ton was last (34\%).

It is interesting to note that only Skelton attracted a proportionately greater number of lower income families than did the average nighttime program.

"Jack Paar," "Brinkley's Journa1," and "Todey." Al1 three of these programs were found to be more attractive than average to familles earning $\$ 7000$ or more. "Brinkley's Journal" drew a particular1y large segment of this income group (47\% of the program's audience was made up of members of families claiming incomes of $\$ 7000$ or more).

The "Jack Paar" and "Today" audiences, at the same time, contained $39 \%$ people who came from families earning in excess of $\$ 7000$.

E. General observations

Upon examining Tables 19 and 20 somewhat closer, the following points become clear:

(1) More sophisticated music programs (1.e., Concert Music) tended to attract members of families whose incomes would be considered in the higher brackets. 
(2) Variety programs presented in the evening tended to attract the higher Income families, whereas the opposite was true of varlety programs presented in the daytime.

(3) W1th the possible exception of Westerns, no really significant differences appeared in the distribution of families viewing nighttime dramatic programs. In the case of Westerns, $68 \%$ of the audience claimed incomes of less than $\$ 7000$, making this program type somewhat more attractive to the lower income-level famlly. No other individual dramatic program types varied more than two percentage points from the average nighttime program.

(4) Dramatic programs telecast during the daytime seemed to be somewhat more attractive to the lower income family than to the higher income family.

(5) With the exception of Quiz Panel (represented by "G.E. College Bowl"), all Audience Particlpation type programs attracted the lower Income-level family.

(6) "Straight talks" programs (1.e., News and Public Affairs) were found relatively attractive by both income categorles; however, Public Affairs programs telecast at night were attracted more to the higher income family than was News. Daytime Public Affairs programs were found slightly more attractive by the "under $\$ 7000$ family" than was the average daytime program; however, the difference was on $1 y$ 1\% -- a rather insigniflcant difference. 
(7) Daytime Sports Events, as stated previously, were viewed much more heavily by the higher income family than that same family viewed television during the average day.

(8) Nighttime Sports Events, on the other hand, were found considerably more attractive to the family earning less than $\$ 7000$ per year.

(9) With one exception (nighttime Children's Drama), children's programs were found more attractive by members of families earning in excess of $\$ 7000$.

(10) Persons coming from families claiming annual incomes of less than $\$ 7000$ were attracted more to Teenage Dance than were persons from higher income-level families.

By now, it should appear quite evident to the reader that there seems to be a correlation between the television viewer's educational background and the Income of the family from which that viewer comes. Again, as in the case of education, the wise televiston advertiser will learn just as much as he possibly can about the income level of viewers of all programs he is serfously interested in sponsoring. 
THE RELATIONSHIP OF PROGRAM-TYPE APPEAL TO FAMILY SIZE

Another very interesting portion of this study pertains to family size, an invaluable subject for many advertisers. For instance, the cereal company would undoubtedly be interested in reaching members of large families. Just about everyone eats cereal, and the larger the family the more cereal it concelvably would consume. The compact car manufacturer, on the other hand, would probably be more interested in reaching relatively small families, for quite obvious reasons.

\section{A. Average Family Size}

In March, 1961, the Bureau of the Census reports that there were 3.36 persons per household in the United States. 1 Since the ARB data pertafning to total sample distribution was not available relative to family size, a comparison for verification purposes could not be made. However, if the ARB family-size average is computed based on actual television viewing (properly weighted), it $1 \mathrm{~s}$ found to be 3.62 persons per household.

Providing that the ARB total sample was distributed properly, and thus agreed substantially with the Bureau of the Census data, it could be concluded that members of larger size families viewed more television

1 U.S. Bureau of the Census, Current Population Reports, Population Characteristics. Household and Family Characteristics: March 1961. Series P-20, Number 116 (U.S. Government Printing Office, Washington, D.C., May 1, 1962), p. 1 . 
than members of smaller size families. However, it is not known whether the two figures are compatible; therefore, such a hypothesis cannot be stated positively, but rather, can only be speculated.

\section{B. Explanation of Data}

ARB has for some time reported family-size information in its TV National Reports. To explain how it is computed, if a viewer to a program comes from a family having four members, and a second viewer comes from a family having two members, then the average family size reported for that specific program would be 3.00 . If there 18 a third viewer, however, who comes from a family of five members, the average family size would be reported as 3.67 . The answer 1 s derived simply by dividing the total number of family members by the total number of homes viewing. A home 18 counted only once regardless of the number of viewers In that home to a spectfic program.

\section{Viewing Patterns of Members of Different Size Families}

There appeared to be a relatively significant difference in viewing by members of large and small size families in the daytime as opposed to the evening hours.

The larger families had more members viewing in the daytime than at night. To explain further, the daytime audience consisted of viewers from families whose average size was 3.90 members. The evening audience, on the other hand, was made up of viewers from families whose average size was 3.57 members. 
Since children generally come from larger size families, and since they contributed a great deal of viewing to daytime television as shown in Chapter $v$, this may possibly be the reason for the overall difference. At any rate, it seems to be an important difference, and one which the advertiser should not overlook.

It Is interesting to look at the two "extreme" program types -. the one which contained viewers comlng from the smallest size family, and the one which contalned viewers from the largest size famlly. According to Figure 1 , the viewers to daytime Public Affairs came from familles whose average slze was 3.08 members. At the opposite pole was daytime ChIldren's Varlety, its viewers coming from famllies whose average slze was 4.56 members. While Public Affairs programs did not show any appreciable change in data insofar as telecast time was concerned, the average famlly size increased slightly to 3.19 at night (Figure 2). Nighttime Children's Variety programs, at the same time, decreased in family-size data to 3.47 , which constituted a substantial difference from daytime programs. This may be due to the programs themselves which constituted the overall program type.

Nighttime Concert Mustc was another type which had members of small size families predominantly in its audience (3.10). Nighttime News programs, too, had a very similar characteristic ( 3.19$)$.

It appears from this discussion thus far that the programs dealing more with educational topics tended to draw viewers from small size families.

Of all the variety programs studied, nlghttime Comedy Variety contained viewers from predominantly larger families (3.51) than the other 


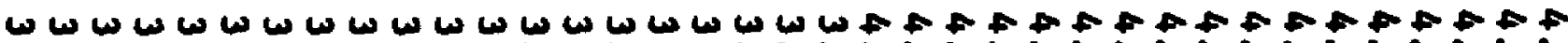

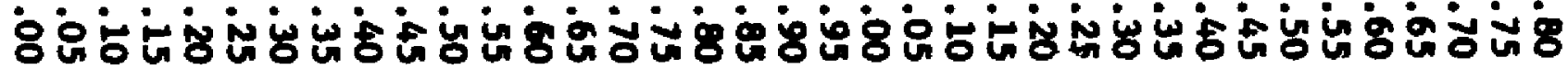
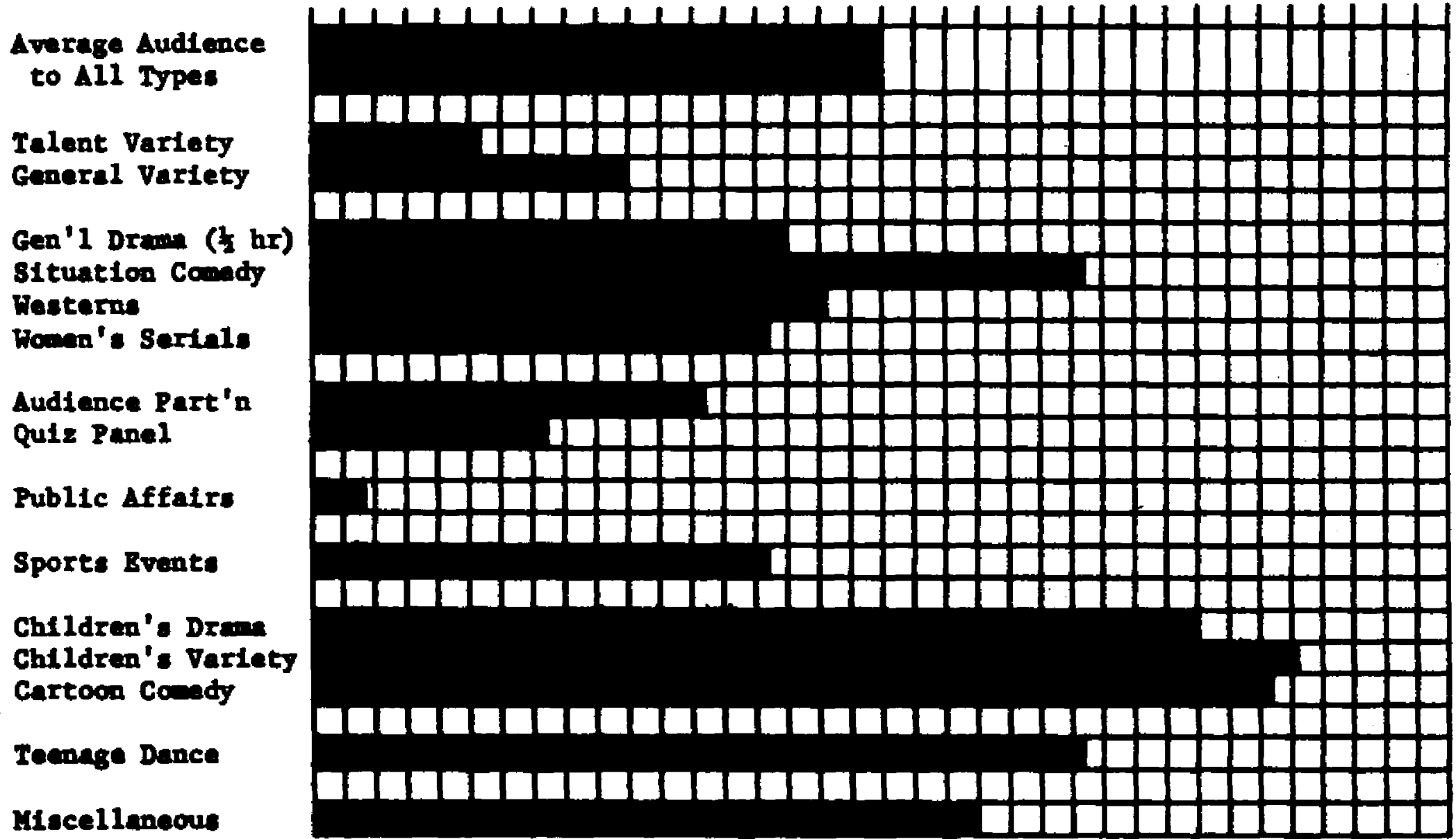

FIGURE 1

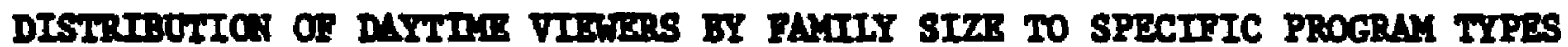
(by number of total faily nembers, In terwa of vievera from those funlles tuned to program type) 
Average Audience to All Type:

Concert Music

Music Varlety Comedy Variety General Varlety

Gen'1 Drama (l $h r$ ) Gen'1 Drama (1 hr) S1tuation Comedy Suspense -Drama Action Adventure Crime Detective Westerns

Peature FIlms

Audience Part'n Game Panel

News

Pub11c Affalro Documentary

Sports Events

Children's Drama ChIldren's Varlety Cartoon Comedy

Miscellaneous

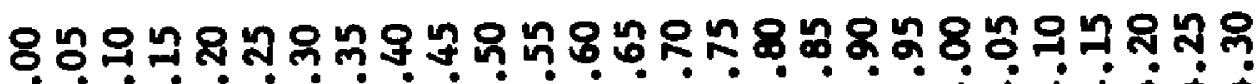

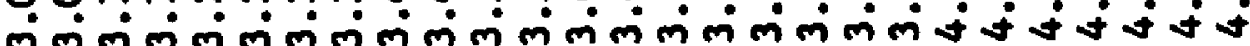

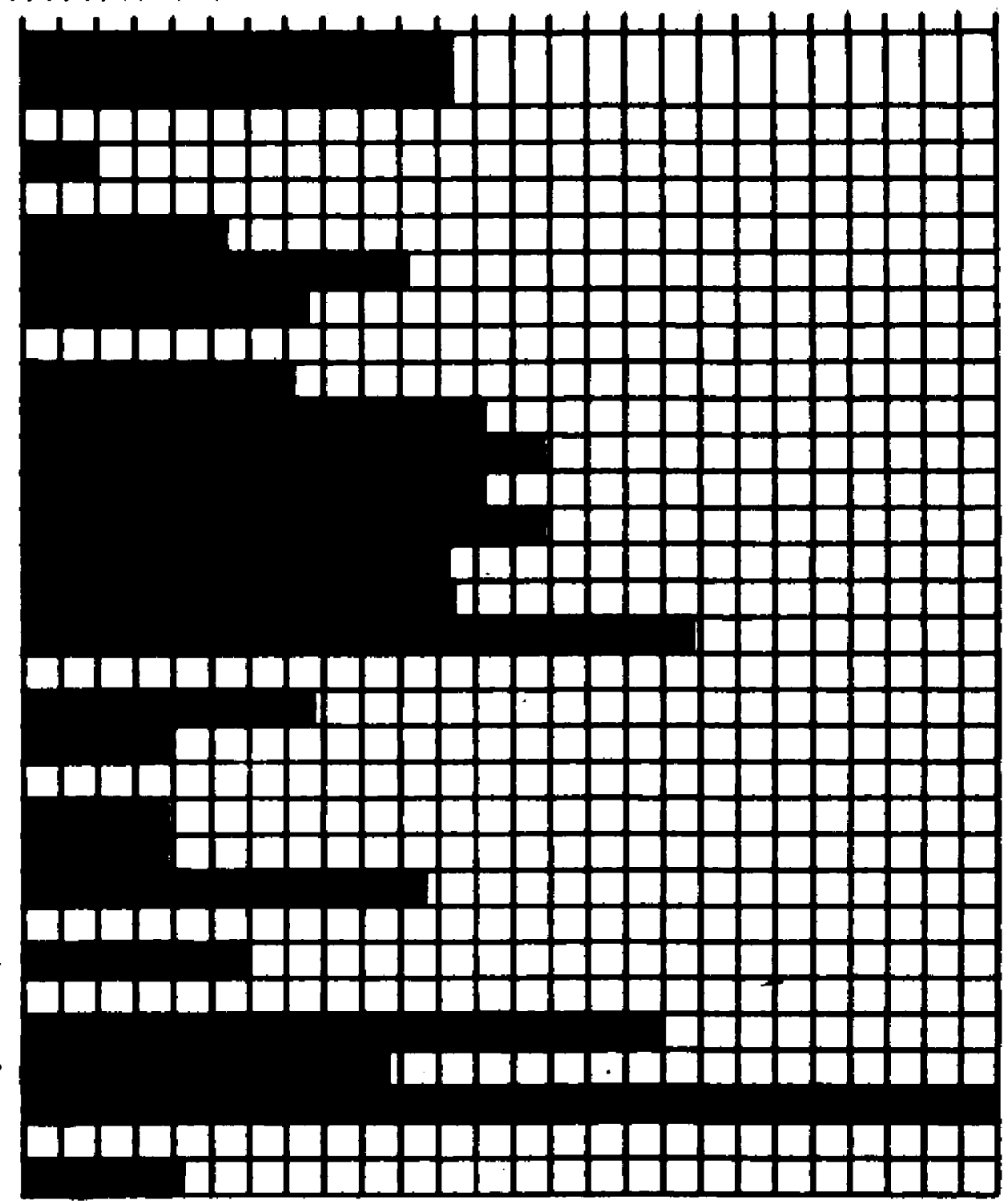

FIGURE 2

DISTRIBUTION OF MIGHTTINE VIEWERS BY FAMILY SIZE TO SPECIFIC PROGRAM TYPES (by number of total famlly members, in terms of viewere from those families tuned to program type) 
types within the broad "variety" classiflcation. The other types Included, and their corresponding famlly-size findings were: (1) daytime -- Talent Variety -- 3.27; General Varlety -- 3.49 (very $81 \mathrm{milar}$ to Comedy Vaxiety); and (2) nighttime -- Music Variety -- 3.27; and General Variety --3.38 .

Except for three "extreme" program types, all dramatic programs tended to be quite stable insofar as average family-size characteristics were concerned. One daytime type (SItuation Comedy) was extremely high in comparison to the other types within the broad drama category. The average viewer to Situation Comedy came from a family which contained 4.22 members. As a comparison, the other daytime dramatic types were substantially lower: General Drama, half-hour -- 3.74; Westerns -- 3.81; and Women's Serials --3.72 .

In the evening, the average half-hour General Drama program was made up of viewers from families whose size was 3.36 members, while Feature Films had a corresponding figure of 3.89 , a rather significant difference. The remaining nighttime dramatic types were somewhat more stable: General Drama, one hour -- 3.61; Situation Comedy -- 3.69; Suspense Drama -- 3.61; Action Adventure -- 3.69; Crime Detect1ve -- 3.56; and Westerns -- 3.57 .

Panel type programs and programs in which the audience participated contalned viewers coming generally from smaller size families. The following findings bear out this statement: (1) daytime -- Audience Participation - 3.62; Quiz Pane1 -- 3.37; and (2) nighttime -- Audience Particlpation -- 3.38; and Game Panel -- 3.20. 
Nighttime Documentary programs (3.53) were found to have conslderably higher famlly-size data than nighttime News and Public Affairs programs, previously discussed.

A signtficant difference in famlly size was found between daytime and nighttime Sports Events. The average viewer to daytime programs, for Instance, came from a family which had 3.71 members, while the average nighttime viewer came from a family of 3.30 members.

With the possible exception of nighttime Children's Variety, children's programs in general boasted very high family-size data. Excluding ChIldren's Variety, which was previously discussed, the findings were as follow: (1) daytime -- Ch1ldren 's Drama -- 4.39; Cartoon Comedy -- 4.52; and (2) nighttime -- Children's Drama -- 3.84; and Cartoon Comedy $=-4.30$

Finally, Teenage Dance, another daytime program type, seemed to attract viewers from large familles. The average viewer came from a family containing 4.22 members.

\section{Discussion of Individual Programs}

Varlations were noted in the family-aize data reported for the programs which are being discussed individually in this study. The data pertinent to these programs have been compiled in Table 22.

"V1deo V1llage, Jr." and "Mr. Wizard." Like most all programs aimed primarily at children, "Video Village, Jr." contalned viewers coming from large size families (4.49). "Mr. Wizard," another children's program, also showed the same high famlly-size data, In that the average 
viewer to that program came from a family whose size was 4.24 members.

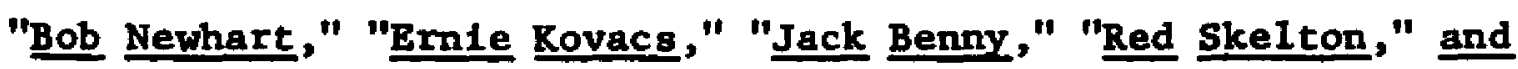
"Steve Allen." With the exceptions of "Ernie Rovacs" (4.03) and "Jack Benny" (3.08), the family-size data for Comedy Variety programs tended to be quite similar, as evidenced by the following: "Bob Newhart" -3.59; "Red Ske1ton" -- 3.60; and "Steve Allen" -- 3.60 .

\section{TABLE 22}
DISTRIBUTION OF VIEWERS BY FAMILY SIZE TO SPECIFIC PROGRAMS
(by total number of famlly members, in terms of viewers from those famlifies tuned to programs)

\begin{tabular}{lc}
\hline \hline Program Name & Total Family Size \\
\hline Video Village, Jr. & 4.49 \\
Mr. Wizard & 4.24 \\
Bob Newhart & 3.59 \\
Ernie Kovacs & 4.03 \\
Jack Benny & 3.08 \\
Red Ske1ton & 3.60 \\
Steve Allen & 3.60 \\
Jack Paar & 3.52 \\
Brinkley's Journal & 3.38 \\
Today & 3.32 \\
\hline
\end{tabular}

"Jack Paar," "Brinkley's Journal" and "Today." The average viewer to "Jack Paar" was from a famlly of 3.52 members, while the corresponding figure for "Brinkley's Journal" was 3.38, and for "Today" was 3.32:

This discussion should be sufficient evidence to show the Importance of information relative to the size of families whose members are in a given program's audience. Like all other data covered in preceding 
chapters, information on family size must not be overlooked by the researcher interested in knowing all facets of viewing behavior. 


\section{SUMMARY AND CONCLUSIONS}

The serious-minded broadcaster -- the one who realizes the Importance of research and does something constructive with the findings of that research -- is undoubtedly the broadcaster who is making a financlal success with his station. In addition, he is probably the broadcaster who is best serving his communtty's interest.

There was a time when research was regarded as a "necessary evil" -- and it unfortunately is still regarded in that 11ght by a few stubborn broadcasters who are so pre-occupied with other "more Important" matters that they will not take the time to really study the value of research.

There are also a select few in the broadcast industry who still deal only in "numbers." They concern themselves merely with the fact that a given program received the highest rating and, therefore, conclude that it reached the best audience. Such a conclusion may or may not be true.

It is hoped that this study will serve to illustrate that ratings by themselves tell very little. In order to fully understand today's viewing audience, qualitative research is vital. Little is accomplished for a program sponsor if the million viewers tuned to his program could not afford to buy his product even if they desired to do so. In this case, he would be far better off with a thousand viewers who are at least "possible" prospects. So, high or low ratings by themselves tell 
very little about the composition of an audience -- only that it is large or sma11.

The findings of this study are relative to four mafor demographic areas: (1) age and sex of viewers, (2) education of viewers, (3) income of families from which viewers come, and (4) size of families which have members viewing television.

\section{A. Major Findings}

The following is a summary of the major findings of the study, broken down by the four areas mentioned above:

(1) Age and Sex of Viewers

(a) The age and sex characteristics of daytime viewers were different in some respects from those of nighttime viewers. In terms of number of persons per 100 homes, more children under 13 years of age were in the daytime audience, as opposed to the evening audience. All other age and sex categorfes, however, were found to have more people per 100 homes in the nighttime audience.

(b) Females dominated males in total number of viewers per 100 homes throughout the broadcast day.

(c) The same program telecast at different hours of the day was viewed by an entirely different audience. This leads one to suspect that at least three factors played important roles in determining the actual audience to a program: (1) the "avallability" of certain segments of the audience to be able to view, (2) the competitive program- 
ming of other stations at the same time, and (3) different "appeals" within the various programs that attracted different people.

(d) Overall, more people (total) viewed television during the evening than during the daytime; however, the proportion of males to females remained relatively constant throughout the broadcast day.

(e) The number of viewers per 100 homes was noticeably less during the daytime than during the evening.

(f) Individual programs within the same program type sometimes varied drastically in composition of audience.

(g) Children under 13 years of age were attracted particularly to S1tuation Comedy, Westerns and all children's programs.

(h) All teenagers found the following types of more than average attractiveness: Talent Variety, S1tuation Comedy, Quiz Panel, Children's Drama, Westerns, Feature FIIms and Teenage Dance. In addition, teenage boys were attracted to daytime Sports Events, Comedy Varlety, nighttime Children's Varlety and nighttime Cartoon Comedy. Teenage girls, on the other hand, vlewed the following types slightly more than they viewed the average program type: nighttime General Drama (half-hour), Suspense Drama and Action Adventure.

(1) Men, 18 to 39 , viewed these progren types more than they 
viewed the average program type: Talent Variety, Quiz Panel, daytime Public Affairs, daytime Sports Events, Comedy Varfety, nighttime General Drama (one hour), Suspense Drama, Action Adventure, Crime Detective, Westerns, Feature Films and Documentary.

(j) Women, 18 to 39 , found the following types particularly attractive: Talent Variety, General Variety, daytime General Drama (half-hour), daytime Situation Comedy, daytime Westerns, Women's Serials, daytime Audience Participation, Quiz Pane1, Teenage Dance, nighttime General Drama (one hour), Suspense Drama, Action Adventure, Crime Detective and Feature Films.

(k) The program types which were found above-average in attractiveness for men over 40 were: Talent Varlety, Quiz Pane1, Public Affa1rs, Sports Events, Concert Music, Music Variety, Comedy Varlety, General Varlety, nighttime General Drama (ha1f-hour), Crime Detective, Westerns, Feature Films, nighttime Audience Participation, Game Pane1, News and Documentary.

(1) Those program types viewed more than average by women over 40 were: Talent Variety, General Variety, General Drama (half-hour), Women's Serlals, Audience Particlpation, Quiz Panel, Public Affairs, Concert Music, Music Variety, Comedy Variety, Game Panel and News. 
(2) Education of Viewers

(a) The average college-educated person did not view as much television as did the average person with less than thirteen years of schooling.

(b) More sophisticated programs (Concert Music, News and Pub11c Affairs) tended to attract the more sophisticated viewer, in terms of educational background.

(c) Overall, there was no significant difference in the educational background of daytime televiston viewers as opposed to those who viewed in the evening. However, some differences were apparent within certain program types.

(d) Variety programs telecast in the evening tended to attract the viewer with more education; however, the reverse was true of daytlme varlety.

(e) Nighttime half-hour dramas attracted a more educated housewife audience than did the average nighttime dramatic program.

(f) Westerns telecast in the evening attracted particularly those heads of households and housewives with less than thirteen years of education.

(g) Nighttime Suspense Drama tended to attract a higher percentage of college-trained heads of households than did the average nighttime dramatic program.

(h) Daytime dramatic programs were generally found more at- 
tractive to people with grammar and high-school educatlons than they were to college-trained people.

(i) The less sophisticated Audience Participation programs drew less-educated audiences. More sophisticated programs, however, attracted audiences with more education.

(j) "Stralght talks" programs were watched to a greater degree by the more educated person. However, News was found significantly more attractive to the high-school and grade-school-educated person than was Public Affalrs.

(k) Daytime Sports Events were viewed more by the Collegetrained head of household and housewife than was the average daytime program. However, nighttime Sports Events were found more attractive by heads of households and housewives with only grade-school or high-school training.

(1) Heads of households and housewives with a grade-school or high-school education were attracted far more to Teenage Dance than was the colllege-educated person.

(3) Income of Families from which Viewers Come

(a) There were no substantial overall differences in the incomes of famllies viewing in the daytime as opposed to those viewing in the evening.

(b) More sophisticated music programs tended to attract members of families whose incomes would be considered in the upper brackets. 
(c) With the possible exception of Westerns, no really signtficant differences appeared in the distribution of families viewing nighttime dramatic programs. Hesterns were found more attractive to the lower income-level family.

(d) Dramatic programs telecast during the daytime seemed to attract the lower income family to a greater extent than dramatic programs telecast in the evening.

(e) With the exception of Quiz Panel, all Audience Participation type programs attracted the lower income-level family.

(f) "Straight talks" programs were found relatively attractive by both income-level families; however, Public Affairs programs telecast at night were attracted more to the higher Income famlly than was News.

(8) Daytime Sports Events were viewed more heavily by the higher income-level family than that same family viewed television during the average day. However, nighttime Sports Events were found considerably more attractive to the family earning less than $\$ 7000$ per year.

(h) With one exception (nighttime Children's Drama), children's programs were found more attractive by members of families earning in excess of $\$ 7000$.

(1) Persons coming from families claiming annual incomes of less than $\$ 7000$ were attracted more to Teenage Dance than were persons from higher income-level families. 
(4) Size of Families from wh1ch Viewers Come

(a) In the particular three-month period during which the surveys for this study were performed, members of larger size families viewed more television than members of smaller size families.

(b) Larger size famflies had more members in the daytime viewing audience than they did in the evening viewing audience.

(c) Most of the program types which would be considered "educationa1" in nature (Concert Music, News and Public Affa1rs) were found to attract persons predominantly from small families.

(d) Children's programs tended to attract members of large size families.

(e) In relation to the distribution of daytime viewers by family size, the following types were viewed more by persons coming from smaller size families than the so-called "average" program type: Talent Variety, General Varlety, General Drama (half-hour), Westerns, Women's Serfals, Audience Participation, Quiz Panel, Public Affalrs and Sports Events.

(f) In relation to the distribution of daytime viewers by family size, the following types were viewed more by persons coming from larger size famllies than the so-called "average" program type: Situation Comedy, Children's Drama, Children's Variety, Cartoon Comedy and Teenage Dance. 
(g) In relation to the distribution of nighttime viewers by family size, the following types were vlewed more by persons coming from gmaller size families than the so-called "average" program type: Concert Music, Music Variety, Comedy Varlety, General Varlety, General Drama (halfhour), Crime Detective, Audience Participation, Game Pane1, News, Public Affalrs, Documentary, Sports Events and Children's Variety.

(h) In relation to the distribution of nighttlme viewers by famlly size, the following types were viewed more by persons coming from larger size families than the so-called "average" program type: General Drana (one hour), Situation Comedy, Suspense Drama, Action Adventure, Westerns (same as "average"), Feature FIlms, ChIldren's Drama and Cartoon Comedy.

With the ever-increasing Interest in media research, it is speculated that more and more studies of this nature will be performed in the future. The information provided by such studies will definitely help pinpolnt the best "vehicle" for any given advertiser's commerclal message.

There was a time when mall-response and the next-door neighbor's "over-the-fehce" coments were the two best "Indications" of what a program's audience was 11ke. Such 1s no longer the case. Today's broadcast industry now has at its fingertips almost any combination of crosstabulations which can be produced utilizing fleld-work which, in many cases, has already been performed by one of the several research organt- 
zations in the country. What is needed to create such tabulations 18 a little Imagination and a "feel" for what the Industry really needs In the way of research.

In conclusion, the writer sincerely hopes that this study accomplishes at least two objectives: (1) helps serve as a working "tool" for the educator as well as the broadcaster, and (2) helps create a demand and a destre for similar type studies in the future. 


\section{BIBLIOGRAPHY}

\section{BOoks}

Chase, Franc18, Jr., Sound and Fury. New York: Harper and Brothers, 1942. 303 pp.

Chester, Giraud, and Garnet R. Garrison, Television and Radio. New York: Appleton-Century-Croft8, Inc., 1956. 652 pp.

Dunlap, Orrin E., Jr., Radio In Advertising. New York: Harper and Brothers, 1931. 383 pp.

Evans, Jacob A., Selling and Promoting Radio and Television. New York: Printers Ink Publishing Company, Inc., 1954. 348 pp.

Head, Sydney W., Broadcasting in Amerlca. Boston: Houghton Mifflin Company, 1956. 502 PP.

Waller, Judith C., Radio, the Fifth Estate. Boston: Houghton Mifflin Company, 1946. 483 PP.

\section{ARTICLES}

Dorrel1, Ward, "History of Ratings," Sponsor Timebuying Basics (1955), 9 .

Dunville, Robert E., "What Qualitative Research Does," Sponsor Timebuying Basics (1955), 30 .

Broadcasting, LXII (March 19, 1962), 34 .

Radio Broadcast, VII (May, 1925), 89 .

Telev1sion Age, IX (June 11, 1962), 30 .

Television Magazine, XVIII (February, 1961), 30.

Televioion Magazine, XVIII (May, 1961), 41.

Televiston Magazine, XIX (March, 1962), 62. 
UNPUBLISHED MATERIAIS

Hopf, Howard E., and Raymond T. Bedwel1, Jr., "Characterlstics and Program Preferences of Television Listeners in Columbus, Oh1o." Unpub11shed study, The Ohio State University, Columbus, 1959. 10 pp.

Summers, Harrison B., "Radio Programs Carried on National Networks 1926-1956." Unpublished study, The Ohto State UnIversity, Columbus, January, 1958. 228 pp.

Summers, Harrison B., "Television Network Program Trends." Unpub11shed material prepared for Television Programs course, The Ohio State University, Columbus, 1957.

\section{GOVERNMENT PUBLICATIONS}

U.S. Bureau of the Census, U.s. Census of Population: 1960. General Soclal and Economic Characteristics, United States Summary. Final Report $\overline{\mathrm{PC}}(1)-1 \mathrm{C}$. Washington: U.S. Government Printing Office, 1962. 344 PP.

U.S. Bureau of the Census, Current Population Reports, Population Characteristics. Household and Family Characteristics: March 1961. Series $\mathrm{P}-20$, Number 116. Waghington: U.S . Government Printing Office, May 1, 1962. 18 pp.

\section{MISCELIANEOUS}

A New Look at the Television Viewer Diary. Pamphlet issued by the Amertcan Research Bureau, Washington, D.C., 1956. 16 pp.

TV Measurement for the Sponsor. Booklet issued by the American Research Bureau, Washington, D.C., 1958. 51 pp. 


\section{AUTOBIOGRAPHY}

I, John Richardson Thayer, was born In Westbrook, MaIne, April 14, 1929. I received my grade-school and secondary-school education In the public schools of Windham, Maine, and my undergraduate training at The University of Maine, which granted me the Bachelor of Arts degree in Speech in 1951. From The Ohto State University, I received the Master of Arts degree in Radio and Television Programing in 1952.

After two years in the U.S. Army, and two years with a Portland, Maine television station, I returned to The Ohlo State University for three years to work on the Doctor of Philosophy degree In Radio and Television Programing under Professor Harrison B. Sumers. While in residence there, I was an assistant to Professor Franklin Knower for the first year, an assistant to Professor Summers the following year, and an assistant instructor under Professor Summers during'the third year.

I left the University in 1959 to accept a position with the Radio/Television Department of an advertising agency in Buffalo, New York.

In 1960, I moved to Washington, D.C., where I accepted the position of Market Reports Technical Director at the American Research Bureau, a nationwide television research firm. 